\title{
Hymenoptera Parasitoid, a Suitable Biodiversity Resource for Vineyard Environmental Discrimination
}

\author{
Augusto Loni ${ }^{1} \&$ Andrea Lucchi ${ }^{1}$ \\ ${ }^{1}$ Department of Agriculture, Food and Environment, University of Pisa, Via del Borghetto 80, Pisa, Italy \\ Correspondence: Augusto Loni, Department of Agriculture, Food and Environment, University of Pisa, Via del \\ Borghetto 80, 56124 Pisa, Italy. Tel: 39-050-221-6118. E-mail: augusto.loni@unipi.it
}

$\begin{array}{lc}\text { Received: August 6, } 2014 & \text { Accepted: September 26, } 2014 \quad \text { Online Published: November 15, } 2014 \\ \text { doi:10.5539/jas.v6n12p36 } & \text { URL: http://dx.doi.org/10.5539/jas.v6n12p36 }\end{array}$

\begin{abstract}
Vineyards host a high number of insect species and represent suitable environments to investigate the relationships among arthropod community and environmental biodiversity.

Hymenoptera Braconidae summarize many of the attributes required to a reliable group of bioindicators. Indeed, they represent a complete assemblage of a family taxon and are quite well known from a taxonomical and faunistic point of view, occupying the top of the ecological (trophic) pyramid and occurring in very diverse habitats. Braconidae subfamilies are often linked to a single host order, so directly expressing in some way, a functional role in the environment.

Here we compared the abundance and the community composition of braconid subfamilies in three differently managed vineyards for two years (2012 and 2013). In each vineyard, the community structure resulted quite similar (abundance and composition) during the first part, but significantly diverged in the second part of the research period. Non Metric Dimensional Scale and Permanova Analysis well described the population distribution. The abundance of some subfamilies, consistently with their ecology, resulted significantly related to the habitat variables considered, as showed by the Multiple Regression analysis. The adoption of insecticides seems to not influence negatively braconid populations, probably because the surrounding areas are provided with a rich local vegetation of bushes and trees, where natural enemies can find refuge. The abundance of some subfamilies that adopt an endophagous koinobiont strategy against lepidopteran larvae showed differences statistically significant in the vineyard where the mating disruption technique was adopted, in comparison with their abundance in the other two vineyards.
\end{abstract}

Keywords: agro-ecosystem, habitat determinants, insect population, parasitoids

\section{Introduction}

In Italy vineyards occupy a considerable part of the agricultural landscape, so that the management systems adopted on them could have a crucial influence on the natural capital of the agricultural territory and its functions, usually known as ecosystem services (ES). Among ES, conserving biodiversity is one of the main supporting services that vineyard operators must enhance. This represents a crucial point in agricultural systems, by promoting sustainability, natural balances and resilience, and offering new opportunities for recreation and tourism (Tompkins, Wratten, \& Simpson, 2012). Vineyards are permanent crops that allow a long-term development of species community and are, therefore, particularly suited to host biodiversity studies (Buchs, 2003).

Research in vineyards has historically focused on arthropod pests, with the publication of about 1,000 scientific papers in the last 40 years (Vincent, Isaacs, \& Bostanian, 2012) and approximately 150 species have been considered harmful to the grapevine worldwide (Bentley, Varela, \& Daare, 2005). Unfortunately, researches on natural enemies diversity conducted at the habitat scale are scarce (Fraser et al., 2007) and are mostly focused on the complex of predators or parasitoids of a small number of insect pests (Altieri et al., 1993, Menalled et al., 1999).

Parasitic Hymenoptera have been estimated to represent about 20\% of all insect species (Lasalle \& Gauld, 1991), and about $75 \%$ of those with a parasitoid life style (Santos \& Quicke, 2011), exerting a strong impact on terrestrial ecosystems and playing a crucial role in the regulation of arthropod herbivorous population (Anderson 
et al., 2011; Shaw \& Hochberg, 2001; Shaw, 2006).

Braconidae are one of the largest families among parasitic Hymenoptera. They occur in very diverse habitats and occupy, with few exceptions, the highest trophic levels, harboring a wide range of ecological niches (Wharton, 1993). Braconid species or morphospecies were frequently used to characterize the environmental biodiversity and, more in general, the arthropods inhabiting forests and prairies in tropical and temperate regions (Papp, 1994, Ent \& Shaw, 1998; Gonzáles \& Ruíz, 2000; Whitefield \& Lewis, 2001; Maeto, Noerdjito, Belokobylskij, \& Fukuyama, 2009; Stenbacka et al., 2010) and/or to test different silvicultural management systems (Lewis \& Whitefield, 1999; Maleque et al., 2010).

In a recent study, the braconids listed in biodiversity databases were proposed as useful sources to identify evenly inventoried areas (Santos, Jones, Quicke, \& Hortal, 2010). Nowadays, research dealing with species inventories does not have easy access to public or private funds and is hindered by the difficulty of finding expert taxonomists, as well as by the wide variety and high number of samples collected. The taxonomic problem can be overcome if samples are considered at a higher taxonomic level (family or subfamily instead of genus or species). In this way a great deal of labour could be saved and less taxonomic expertise would be needed (Hoback, Svatos, Spomer, \& Higley, 1999; Veijalainen, Sääksjärvi, Erwin, Gomez, \& Longino, 2012).

Unfortunately, the knowledge of the braconid populations and the functional role that they play as bio-indicators in cultivated crops and in the vineyards are still limited (Loni \& Lucchi 2012). However, braconid subfamilies can represent a well correlated parasitoid-host association scheme, because most of them are restricted to a single host Order, and their compositional biodiversity, at the subfamily level, reflects in some way their functional role (Wharton, 1997a). The first step to link a group of bio-indicators to a particular habitat is to verify if it is representative of the habitat chosen and suited to discriminate between different habitats. In other words, it is important that it well matches specific features of the environment and reacts to any impacts or changes on it (Büchs, 2003).

The local structure and diversity of insect populations in the agro-ecosystems can be strongly affected by the structure of the landscape matrix in which they lie, depending on fragmentation, habitats size and connectivity (Tscharntke et al., 2012) as well as by the mobility and dispersal ability of the studied taxa (Lévesque-Beaudin $\& O$ Wheeler, 2011; Marini, Öckinger, Battisti, \& Bonmarco, 2012). For this reason we selected three vineyards in the same area, with the aim to reduce as much as possible the environmental variability. Our study covers a two-year period and deals with the braconid fauna (Hymenoptera) of three differently managed vineyards in the Province of Pisa (Tuscany, Italy).

In our experimental approach we speculated that the community description of the braconid subfamilies could represent an appropriate indicator to discriminate a vineyard agro-ecosystem, checking how the abundance and the community composition of the braconid subfamilies changed across the vineyards and over the time. In detail, we tested:

i) The null hypothesis that braconid community, at subfamilies taxon level, shows the same level of similarity across different vineyards;

ii) The possible contribution of each subfamily to describe spatial and temporal differences;

iii) The suitability of habitats surrounding the sample sites and local sources to explain braconid abundance and composition;

iv) The possible influence of the different pest management systems adopted in each vineyard on braconid subfamilies population.

\section{Materials and Methods}

\subsection{Study Areas}

The three studied vineyards were labelled as C (Conventional), MD (Mating disruption) and O (Organic), lie in the district of Crespina (Province of Pisa, Tuscany, Central Italy) between 15 and 50 meters above sea level. The vineyard size of $C, M D$ and $O$ is respectively 40 hectares, 30 hectares and 2 hectares. The $\mathrm{O}$ vineyard is small but is located in a large natural area that includes wild vegetation of trees, bushes and herbs. The areas around

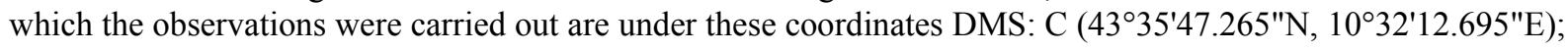
MD $\left(43^{\circ} 35^{\prime} 42.795^{\prime \prime} \mathrm{N}, 10^{\circ} 34^{\prime} 18.241^{\prime \prime E}\right)$ and $\mathrm{O}\left(43^{\circ} 35^{\prime} 5.273^{\prime \prime} \mathrm{N}, 10^{\circ} 32^{\prime} 14.520^{\prime \prime E}\right)$. All the experimental units occur in an area of 3 kilometres in diameter, allowing to reduce the variation of topographical and weather conditions and their borderlines are at least $1 \mathrm{Km}$ away from each other.

We believe this experimental design suitable to prevent overlap of braconid populations from the different areas. 
In effect, as shown in some specific papers, the range of braconid flight is usually limited to the area around the release point (Langhof, Meyhöfer, Poehling, \& Gathmann, 2005; Wanner, Hattendorf, Günther, \& Dorn, 2007; Scarratt, Wratten \& Shishehbor, 2008). In each vineyard, the control of the main insect pest, the grapevine moth Lobesia botrana, has been conducted in different ways in the last seven years: C continuously adopted a conventional strategy based on organophosphate insecticides, MD only pheromone mating disruption with Isonet $\mathrm{L}$ dispensers and $\mathrm{O}$ no insecticide treatments at all.

As regards the control of downy mildew and powdery mildew, seven treatments were annually adopted in the three vineyards with the following active ingredients: Dimetomorph, Cimoxamil, Mancozeb, Phosetil-Al and Sulfur in C; only Copper and Sulfur in MD and O.

All the vineyards have been planted more than 9 years ago and their agronomic characteristics (density per hectare, cultivated varieties, age of the vineyards) are similar.

\subsection{Braconid Sampling}

Braconids have been surveyed by using Malaise traps, which are considered the most appropriate devices to catch insects flying in a hypothetical layer of 0-3 m (Papp, 1994; Lewis \& Whitefield, 1999; Fraser, Dytham, \& Mayhew, 2007). Two Malaise traps were installed in each vineyard, one approximately in the centre and the other near one edge, at a distance of at least $60 \mathrm{~m}$ apart. The traps continuously worked from the end of May to the first week of October in 2012 and from half May to the first week of October in 2013. Insects were collected every two weeks obtaining eighteen samples per vineyard in 2012 and twenty in 2013. In this way we covered all the productive season of the grapevine, as well as the main flying season of the parasitoids (Fraser, Dytham, \& Mayhew, 2007). We considered that the position of the two Malaise and the numerous temporal replications represented a good combination in determining the space-temporal composition of braconid community as well as in giving a measure of the within-vineyard variability (Fraser, Dytham, \& Mayhew, 2008). Braconids were separated from all the other insects and stored in $70 \%$ ethanol at the Department of Agriculture, Food and Environment of Pisa University. They were grouped at the subfamily level according to Sharkey (1997) and Van Achterberg (1993).

\subsection{Habitat Characterization}

\subsubsection{Abiotic Factors}

Temperatures and rains of the two years were obtained from the database of the "Servizio Idrologico Regionale" of Tuscany, selecting the meteorological station of the locality of Cenaia, located in the study area $\left(43^{\circ} 61^{\prime} \mathrm{N}\right.$, $\left.10^{\circ} 54^{\prime} \mathrm{E}\right)$ (http://www.sir.toscana.it/).

\subsubsection{Local Vegetation Assessment}

A complex of vegetation variables were measured to describe the habitat sources. We delimited a circular transect (50 meter ray) around each trap and scored all the trees (woody species higher than 3 meters), the number of the wild, woody shrub species and the surface covered by the grapevine. In each circle a bi-monthly estimation of the surface covered by herbs was conducted by randomly throwing a square grid of $20 \mathrm{~cm}$ of side and by evaluating the herbs covering inside it. Thirty throws were performed in each trap site, visually choosing the zones with macroscopically different herbs occurrence. Trees, shrubs and herbs represent the main structural vegetation components, whose role was already adopted as habitat indicators in determining Ichneumonid abundance and diversity (Fraser et al., 2007). All these measures, recorded in both years, are reported in Appendix A.

\subsection{Data Analyses}

\subsubsection{Braconid Communities Similarity}

The start point of all our analyses for both the years was the raw data matrix reporting an array of rows (braconid subfamilies) and columns (all the Malaise trap samples). Usually the species-abundance distributions within ecological assemblage are strongly right skewed, being most species rare and only a few very abundant. By considering specimens at subfamily taxonomic level, we enhanced such an aspect, because it increases the differences among the subfamilies represented by a lower number of species and those represented by a higher number of species. Based on this assumption we performed a preliminary analysis of draftsman plot to visualize such right-skewed distribution and, after that, we adopted the strongest log-e transformation for all the raw data variables, so reducing the right-skewed distribution and down weighting the most represented subfamilies (Clarke \& Warwick, 2001).

To visualize preliminarily differences or similarities in braconid population we adopted an ordination technique 
as the Non-Metric Multidimensional Scaling (NMDS, usually shortened to MDS) and a method of Hierarchical Agglomerative Clustering, producing a configuration in two dimensions of the braconid subfamilies samples and a dendrogram respectively.

To test the null hypothesis that braconid subfamiliy communities showed the same level of similarity across different vineyards, we used a mixed-model nested permutational multivariate analysis of variance (Permanova), performed on a resemble matrix, based on Bray-Curtis similarity coefficient, calculated on the log-e transformed data of the original raw data matrix. We adopted as factors: vineyard (C, MD, and $\mathrm{O}$ ), trap with two levels (c, central and p, peripheral) and time (collection dates). Vineyard and time were fixed factors, trap was considered a random factor, nested in the vineyard factor. A P value $<0.01$, based on permutation method, was chosen (Anderson, Gorley, \& Clarke, 2008).

The two-trap design adopted gave a measure of within-vineyards variability, which could be significantly affected by the central and peripheral location of the traps. On the other hand, such a location gives a more complete and representative assemblage of insect population, by joining two samples of complementary sites in the same experimental area (Fraser et al., 2008). For that reason we repeated both the Permanova than the MDS and Cluster analysis on a new matrix, obtained cumulating the data of each couple of traps for the years 2012 (Appendixs B) and 2013 (Appendix C). In this second Permanova we adopted a two-way crossed design where only the two fixed factors, vineyard $(\mathrm{C}, \mathrm{MD}$, and $\mathrm{O})$ and period with three levels $(1,2,3)$, were considered. Each level of the term "period" groups three consecutive sample dates, because a preliminary observation of the MDS representation in 2012 clearly showed a cloud of samples grouping the first three dates of collection. Further, in this way, we reduced the probability to find some significant differences across the high number of dates, just as result of a stochastic event. In 2013 we collected samples of ten different dates, so that the Permanova analysis, performed adopting the term "period", produced an unbalanced design with the levels 1 and 2, each one grouping three dates and the level 3 grouping the last four dates. We considered such data adopting sums of square called Types III, where every term in the model is fitted only after taking into account all other terms in the full model. Also in these cases a P value $<0.01$ was adopted (Anderson, Gorley, \& Clarke, 2008).

\subsubsection{Braconid Subfamilies Similarity Percentage Contribution}

The evaluation of the contribution of each subfamily to the (dis)-similarity among the samples was performed by a Simper analysis (similarities percentage), which decomposes average Bray-Curtis dis-similarities into percentages from each subfamilies, both within a group or between all pairs of groups considered, listing them in decreasing order of such contributions. The analysis was conducted taking into consideration vineyard and time factors and was applied only on the resemble matrix, based on the couple-cumulated trap data, considered more representative of the braconid community assemblage (Appendices D, E, F, G) (Clarke \& Warwick, 2006).

\subsubsection{Habitat Variables and Populations Correlation}

To relate the braconid community structure to the habitat variable(s) defined in paragraph 2.3.2, we tested the null hypothesis that such variable(s) were not associated to any of the subfamilies abundance by using a distance-based linear model analysis, adopting a step-wise selection procedure and an adjusted $\mathrm{R}^{2}$ selection criteria. $\mathrm{P}$ values for testing the null hypothesis are obtained using a permutation method. Obviously the linear model analysis adopted, by matching all the habitat variables with all the 17 subfamilies, could produce some positive (or negative) correlations, statistically significant, just as result of a stochastic event. For this reason we considered only those subfamilies that resulted significantly correlated $(\mathrm{P}<0.05)$ to the same habitat variable in both years and that, at least for one year, showed a statistical significance with a $\mathrm{P}$ value $\leq 0.005$.

All these analyses were performedby using the Primer Program v6, 2nd edition (Clarke \& Warwick, 2001, 2006) and the Permanova+ for Primer (Anderson, Gorley, \& Clarke, 2008).

\subsubsection{Subfamily Differences Among Different Management Systems}

We collated the subfamily functional biodiversity among the three vineyards, by verifying the null hypothesis of no differences in the abundance of braconid subfamilies among the vineyards in the season. We adopted the Kruscal-Wallis one-way analysis of variance by ranks to test if each subfamily was statistically different in the three vineyards (Siegel \& Castellan, 1998). We chose a P value $<0.05$. We discussed differences among distribution of different subfamilies adopting the main guilds of braconids, based on the combination of the presumed principal hosts in the literature and on the parasitisation strategies (koiniobiont or idiobiont) (Wharton, 1997a). We considered six guilds, koinobionts of Lepidoptera (KL), koinobionts of Diptera (KD), koinobionts of Coleoptera (KC), koinobionts of Aphids (KA), idiobionts of both Lepidoptera and Coleoptera (ICL) and idiobionts of Coleoptera (IC). All data were analyzed separately for each year of the study. 


\section{Results}

\subsection{Year 2012}

\subsubsection{Abiotic Factors}

Rains occurred only at the beginning and at the end of the study period, whereas it did not rain from the half of June to the end of August. On the contrary, temperatures were within the range of the values recorded in the previous years (http://www.sir.toscana.it). The summer dryness strongly influenced the growth and the presence of the wild cover crops in the vineyards.

\subsubsection{Braconid Subfamily Community}

The six Malaise traps ( 2 per vineyard) overall captured 8,356 individuals belonging to 17 subfamilies. Almost all the subfamilies were represented in the three vineyards except for Neonerinae, captured only in MD and C, Macrocentrinae only in $\mathrm{C}$ and $\mathrm{MD}$ and Miracinae only in $\mathrm{O}$ and $\mathrm{C}$. The most abundant subfamilies were Microgastrinae, Aphidinae and Alysiinae, including approximately the $60 \%$ of the total specimens captured. Euphorinae, Cheloninae and Braconinae were well represented in the collections, whereas captures of specimens belonging to the subfamilies Macrocentrinae (12), Meteorinae (4) and Neoneurinae (2), resulted singleton or doubleton in any samples. The most abundant captures were recorded in the vineyard MD (3,625 specimens), followed by $\mathrm{C}$ with 2,666 Braconids and $\mathrm{O}$ with 2,065 specimens (Table1).

Table 1. Total captures cumulated for each vineyard and Subfamily in 2012 and 2013

\begin{tabular}{|c|c|c|c|c|c|c|c|c|c|}
\hline \multicolumn{5}{|c|}{2012} & \multicolumn{5}{|c|}{2013} \\
\hline Subfamily & $\mathbf{C}$ & MD & $\mathbf{O}$ & Total & Subfamily & $\mathbf{C}$ & MD & $\mathbf{O}$ & Total \\
\hline Agathidinae & 57 & 212 & 21 & 290 & Ag & 10 & 79 & 29 & 118 \\
\hline Alysiinae & 221 & 696 & 226 & 1143 & Al & 189 & 561 & 99 & 849 \\
\hline Aphidiinae & 444 & 973 & 356 & 1773 & Aph & 88 & 405 & 129 & 622 \\
\hline Braconinae & 209 & 123 & 112 & 444 & $\mathrm{Br}$ & 126 & 48 & 99 & 273 \\
\hline Cheloninae & 380 & 77 & 162 & 619 & Ch & 77 & 31 & 106 & 214 \\
\hline Doryctinae & 10 & 21 & 78 & 109 & Do & 4 & 6 & 18 & 28 \\
\hline Euphorinae & 169 & 338 & 155 & 662 & $\mathbf{E u}$ & 74 & 158 & 152 & 384 \\
\hline Helconinae & 103 & 73 & 43 & 219 & He & 33 & 18 & 29 & 80 \\
\hline Homolobinae & 93 & 27 & 57 & 177 & Hom & 128 & 38 & 125 & 291 \\
\hline Hormiinae & 25 & 19 & 13 & 57 & Hor & 7 & 8 & 4 & 19 \\
\hline Macrocentrinae & 9 & 3 & & 12 & Mac & 13 & 2 & 7 & 22 \\
\hline Meteorinae & 2 & 1 & 1 & 4 & Met & 4 & 4 & 1 & 9 \\
\hline Microgastrinae & 718 & 842 & 680 & 2240 & Mig & 621 & 433 & 510 & 1564 \\
\hline Miracinae & 17 & & 24 & 41 & Mir & 3 & 2 & 1 & 6 \\
\hline Neoneurinae & & 2 & & 2 & $\mathrm{Ne}$ & 1 & 1 & & 2 \\
\hline Opiinae & 96 & 104 & 50 & 250 & Op & 52 & 70 & 50 & 172 \\
\hline Rogadinae & 113 & 114 & 87 & 314 & Ro & 59 & 35 & 52 & 146 \\
\hline Total & 2666 & 3625 & 2065 & 8356 & Total & 1489 & 1899 & 1411 & 4799 \\
\hline
\end{tabular}

\subsubsection{Braconid Communities Similarity}

The NMDS representation related to the assemblage of all the single trap samples showed in the upper-left part of the graphic a higher concentration of samples collected during the first weeks of the research period (Figure 1A). Such observations well matched with the results of the permanova analysis which reported strongly significant differences due to the "Time" and "Trap" factors, without significant interaction (Table 2A). The NMDS graphical representation, performed on the trap-joined data, showed a clearer situation about sample similarity. In the upper-left part there is a concentration of all the three vineyard samples, collected during the 
first three dates, but in the lower and right part of the graphic there are three groups which distinctly separated the populations of the three vineyards.

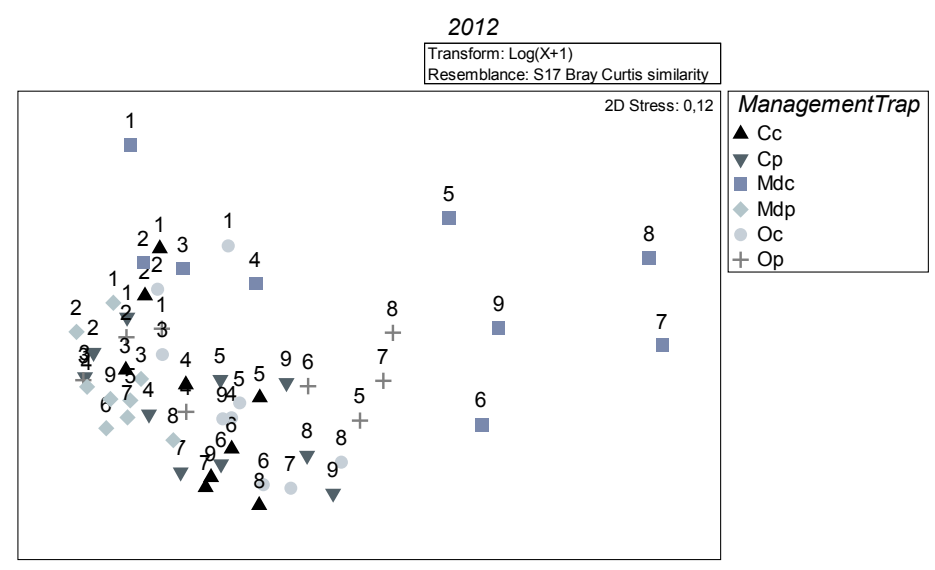

(A)

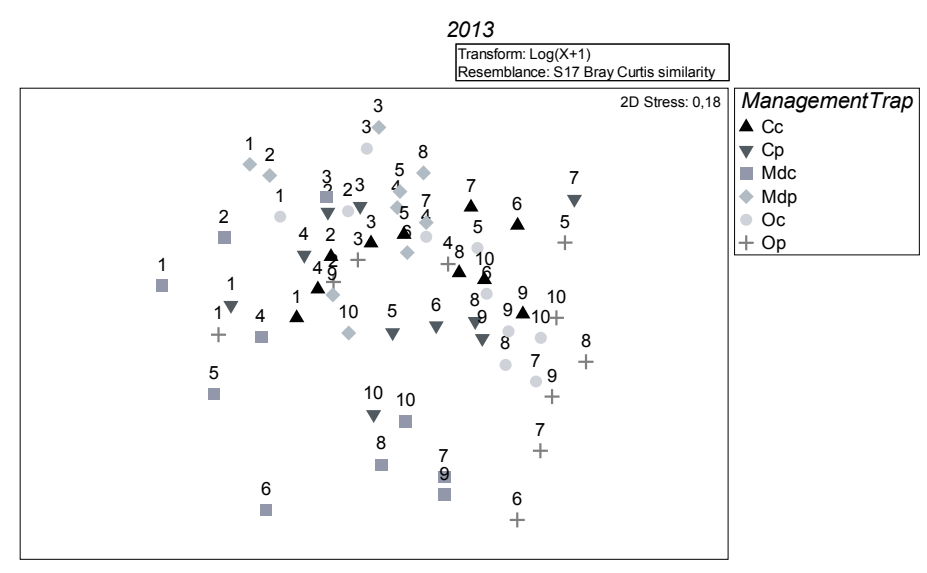

(B)

Figure 1. MDS representation of the similarity of single trap samples (A, 2012; B, 2013). Numbers labelling the symbols represent the progressive dates of collection, the symbols in the caption the combination of the factor vineyard: (C) Conventional, (MD) Mating disruption, (O) Organic and the factor trap position; (c) central, (p) peripheral

Table 2. Results of the mixed-model nested PERMANOVA global test (A2012, B2013)

Table 2A.

\begin{tabular}{lllllll}
\hline $\mathbf{2 0 1 2}$ & & & & & & \\
\hline Source & df & SS & MS & Pseudo F & P & Unique (perm) \\
\hline Vi & 2 & 7630.3 & $3,815.1$ & 0.89 & 0.5952 & 15 \\
Ti & 8 & 22883 & 2860.4 & 5.63 & $\mathbf{0 . 0 0 0 1}$ & 9905 \\
Tr(Vi) & 3 & 12727 & 4242.3 & 8.35 & $\mathbf{0 . 0 0 0 1}$ & 9929 \\
VixTi & 16 & 8053 & 503.31 & 0.99 & 0.5177 & 9844 \\
Res & 24 & 12197 & 508.2 & & & \\
Total & 53 & 63490 & & & & \\
\hline
\end{tabular}


Table 2B.

\begin{tabular}{lllllll}
\hline $\mathbf{2 0 1 3}$ & & & & & & \\
\hline Source & df & SS & MS & Pseudo F & P & Unique (perm) \\
\hline Vi & 2 & 7622.2 & 3811.1 & 1.7 & 0.07 & 15 \\
Ti & 9 & 24639 & 2737.7 & 5.67 & $\mathbf{0 . 0 0 0 1}$ & 9907 \\
Tr(Vi) & 3 & 6724.6 & $2241 . €$ & 4.64 & $\mathbf{0 . 0 0 0 1}$ & 9943 \\
VixTi & 18 & 91060 & 508.89 & 1.054 & 0.37 & 9838 \\
Res & 27 & 13037 & 482.84 & & & \\
Total & 59 & 61183 & & & & \\
\hline
\end{tabular}

Vineyard (Vi), Time (Ti), Trap (Tr), Tr (Vi) indicates that factor Trap is nested in Vi. P values significant are in bold.

Such distribution is well underlined by superimposing also the groups resulting by the cluster analysis at the similarity level of $73 \%$ (Figures $2 \mathrm{~A}$ and $3 \mathrm{~A}$ ). Permanova analysis confirmed the sample distribution of NMDS, showing significant differences due to the vineyard, as well as to the period factors. No significant interaction resulted between the two factors (Table 3A).

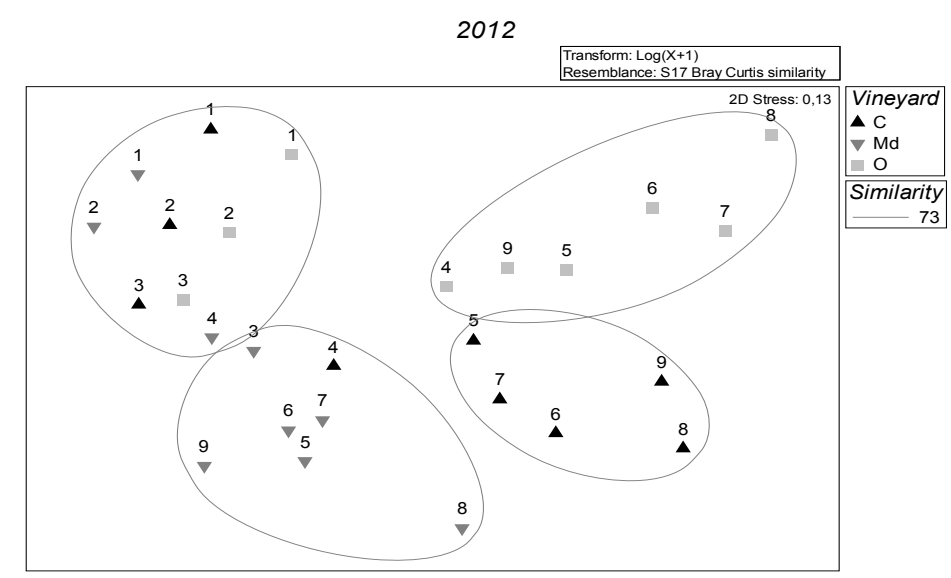

A

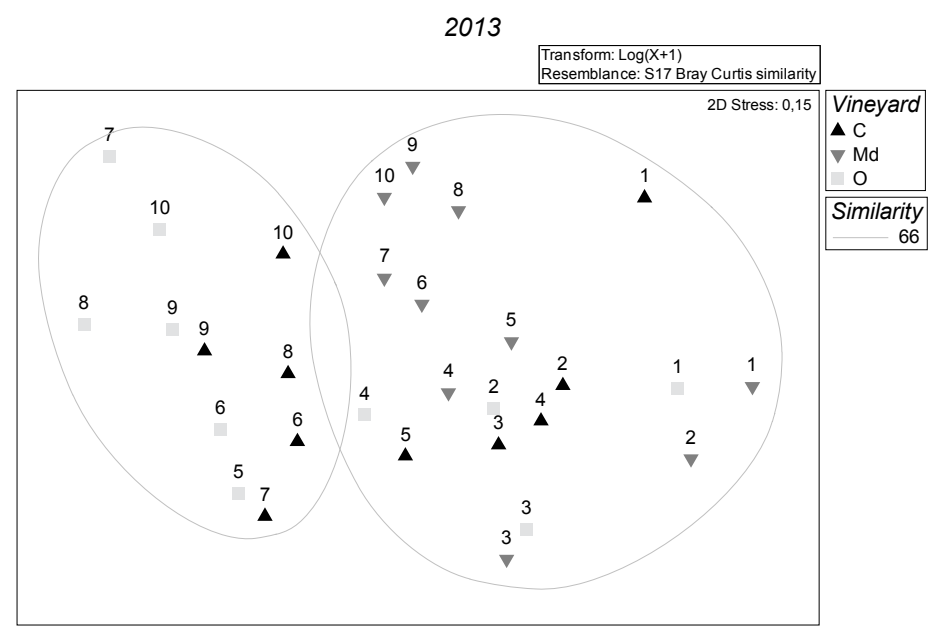

B

Figure 2. MDS representation of the sample similarity by pooling the captures of each couple of site traps (A, 2012; B, 2013). Different symbols represent the differently managed vineyards, (C) Conventional, (MD) Mating disruption, (O) Organic. Numbers represent the progressive dates of collection 


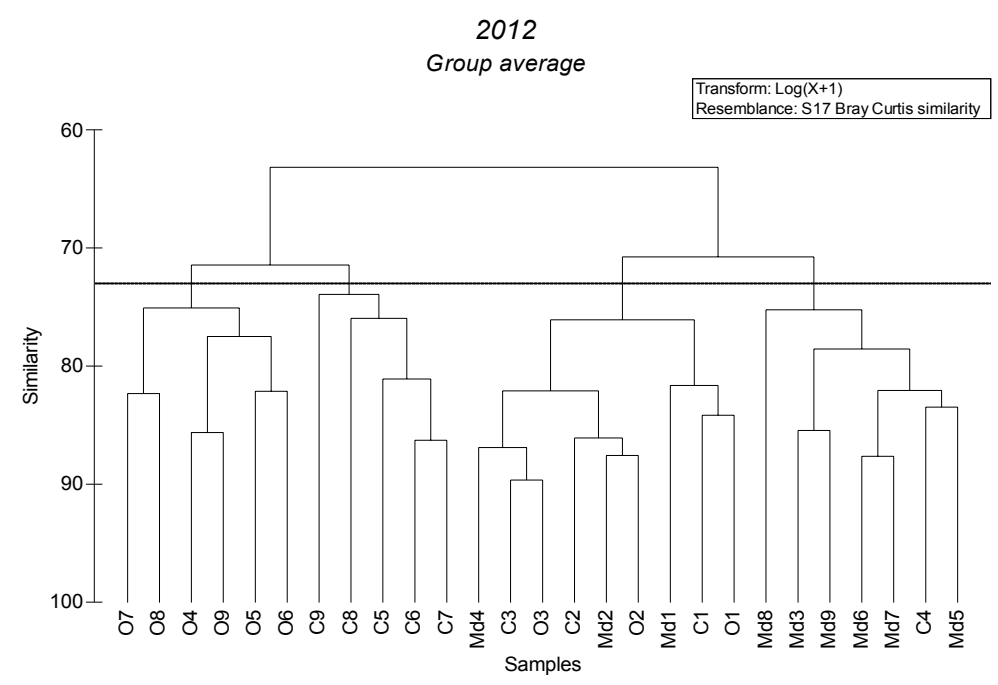

A

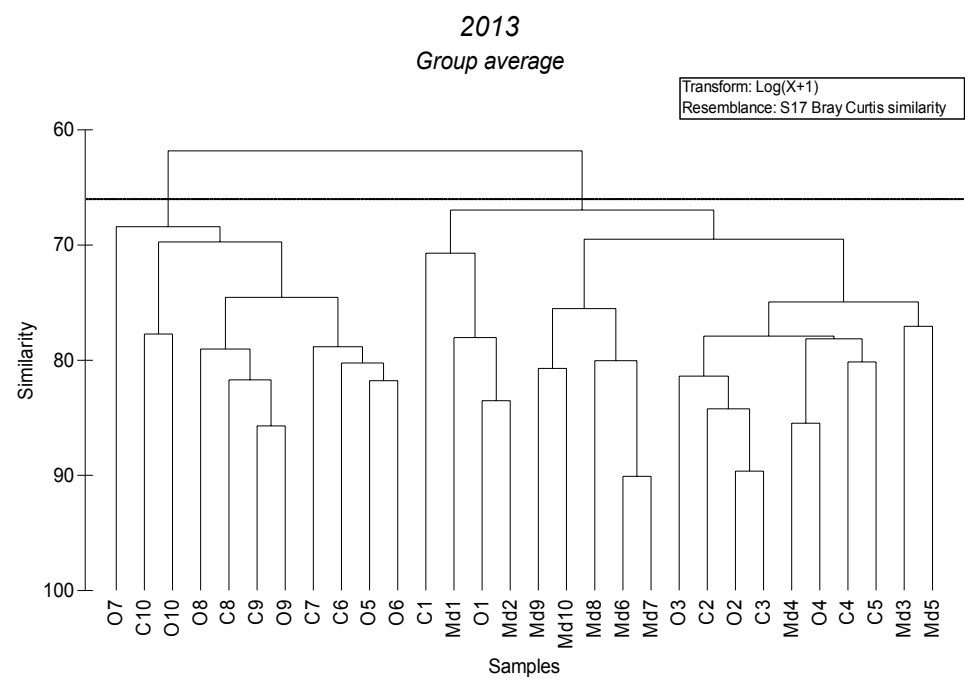

$\mathrm{B}$

Figure 3. Cluster representation of the sample similarity by pooling the captures of each couple of site traps (A, 2012; B, 2013). (C) Conventional, (MD) Mating disruption, (O) Organic. Numbers represent the progressive dates of collection

Table 3. Results of the mixed-model PERMANOVA global test on the captures of each couple of traps pooled together (A2012, B2013)

Table 3A.

\begin{tabular}{llllllc}
\hline $\mathbf{2 0 1 2}$ & & & & & & \\
\hline Source & df & SS & MS & Pseudo F & P (perm) & Unique perms \\
\hline Vineyard & 2 & 3196.1 & 1598 & 6.26 & $\mathbf{0 . 0 0 0 1}$ & 9940 \\
Period & 2 & 4773.9 & 2386.9 & 9.35 & $\mathbf{0 . 0 0 0 1}$ & 9933 \\
VixPe (Interaction) & 4 & 1187.8 & 296.96 & 1.16 & 0.29 & 9915 \\
Res & 18 & 4597.2 & 255.4 & & & \\
Total & 26 & 13755 & & & & \\
\hline
\end{tabular}


Table 3B.

\begin{tabular}{lllllll}
\hline $\mathbf{2 0 1 3}$ & & & & & & \\
\hline Source & df & SS & MS & Pseudo F & P (perm) & Unique perms \\
\hline Vineyard & 2 & 2745.2 & 1693.2 & 4.648 & $\mathbf{0 . 0 0 0 1}$ & 9936 \\
Period & 2 & 6586.8 & 3293.4 & 11.15 & $\mathbf{0 . 0 0 0 1}$ & 9938 \\
VixPe (Interaction) & 4 & 1447.9 & 361.98 & 1.23 & 0.246 & 9917 \\
Res & 21 & 6201.6 & 295.31 & & & \\
Total & 29 & 17164 & & & & \\
\hline
\end{tabular}

$\mathrm{P}$ values significant are in bold.

Consistently the pair-wise tests of Permanova for the term "period" produced significant differences between period 1 versus periods 2 and 3, higher of that emerged by confronting the period 2 versus 3 (Table 4A).

Table 4. Results of the mixed-model PERMANOVA pair-wise test on the captures of each couple of traps pooled together, performed on the term "Vineyard": Conventional (C), Mating disruption (MD), Organic (O) and the term period (A 2012, B 2013)

Table 4A.

\begin{tabular}{|c|c|c|c|c|c|c|c|}
\hline \multicolumn{8}{|c|}{2012} \\
\hline Vineyard & $\mathbf{t}$ & $P($ perm $)$ & Unique perms & Period & $\mathbf{t}$ & $P($ perm $)$ & Unique perms \\
\hline $\mathrm{C}, \mathrm{MD}$ & 2.18 & 0.0012 & 9952 & $1-2$ & 3.16 & 0.0005 & 9953 \\
\hline $\mathrm{C}, \mathrm{O}$ & 2.39 & 0.002 & 9945 & $1-3$ & 3.9 & 0.0002 & 9952 \\
\hline MD, $\mathbf{O}$ & 2.89 & 0.0003 & 9959 & $2-3$ & 1.69 & 0.03 & 9957 \\
\hline
\end{tabular}

Table 4B.

\begin{tabular}{|c|c|c|c|c|c|c|c|}
\hline \multicolumn{8}{|c|}{2013} \\
\hline Vineyard & $\mathbf{t}$ & $P($ perm $)$ & Unique perms & Period & $\mathbf{t}$ & $\mathbf{P}($ perm) & Unique perms \\
\hline $\mathrm{C}, \mathrm{MD}$ & 2.24 & 0.0004 & 9948 & $1-2$ & 2,79 & 0.0007 & 9957 \\
\hline $\mathrm{C}, \mathbf{O}$ & 1.34 & 0.13 & 9959 & $1-3$ & 4,44 & 0.0001 & 9948 \\
\hline MD, $\mathbf{O}$ & 2.68 & 0.0004 & 9942 & $2-3$ & 2,27 & 0.0004 & 9941 \\
\hline
\end{tabular}

Values significant are in bold.

\subsubsection{Subfamilies Similarity Contribution}

The average Bray-Curtis similarity across the vineyard sample groups, ranged from 70.32 (C) and 74.69 (MD). The subfamily Microgastrinae gave the main contribution to the average similarity in all the groups and the ratio of its average contribution, divided by the SD across the within-group similarity, was relatively high. It means that this subfamily is well represented and quite well distributed in all the replicates within each group. In less extent, good contributes to the typification of $\mathrm{C}$ are given also by Braconinae and Cheloninae. Alysiinae and Agathidinae contributed in typifying MD, whereas Cheloninae, Braconinae and Doryctinae contributed at the same level for O. As regards the analysis of the dissimilarity between all pairs of the group samples, Aphidiinae and Alysiinae are the most discriminating subfamilies for all the three pairs of the group samples, but some contributes were given by Euphorinae, Agathidiinae and Cheloninae in the dissimilarity between vineyard $\mathrm{C}$ versus $\mathrm{MD}$, Doryctinae in the dissimilarity of $\mathrm{C}$ vs $\mathrm{O}$ and Agathidiinae and Doryctinae in the dissimilarity of MD vs $O$ (Appendix D). The simper performed on the base of the time factor sample groups (1-9), gave similarity average values that resulted higher for the first weeks if confronted with values registered in the second part of the research period. Again, Microgastrinae were the subfamily that mostly typified the week factor samples, being always at the top of the list except for the first two weeks, which were headed by Aphidiinae. Values of the 
average dissimilarity progressively decrease when the dates of the samples are progressively closer to each other (Appendix E).

\subsubsection{Habitat Variables and Population Correlation}

The abundance of Alisyiinae, Euphorinae and Aphidiinae was significantly related to the presence of herbs. Differently, abundance of Doryctinae resulted positively correlated with trees and bushes abundance and surface covered by grapevine within the transect (Table 5).

Table 5. Results of distance-based linear model analysis, adopting a step-wise selection procedures and an adjusted R2 selection criteria. Only subfamilies that showed significant correlation with habitat variables were reported

\begin{tabular}{|c|c|c|c|c|c|c|c|c|c|}
\hline \multicolumn{5}{|c|}{2012} & \multicolumn{5}{|c|}{2013} \\
\hline \multirow[b]{2}{*}{ Subfamily } & \multicolumn{4}{|c|}{ Habitat variables } & \multirow[b]{2}{*}{ Subfamily } & \multicolumn{4}{|c|}{ Habitat variables } \\
\hline & $\begin{array}{c}\text { Trees } \\
\text { abundance }\end{array}$ & $\begin{array}{c}\text { Bushes } \\
\text { abundance }\end{array}$ & $\begin{array}{l}\text { Herbs } \\
\text { surface }\end{array}$ & $\begin{array}{c}\text { Grapevine } \\
\text { Surface }\end{array}$ & & $\begin{array}{c}\text { Trees } \\
\text { abundance }\end{array}$ & $\begin{array}{c}\text { Bushes } \\
\text { abundance }\end{array}$ & $\begin{array}{l}\text { Herbs } \\
\text { surface }\end{array}$ & $\begin{array}{c}\text { Grapevine } \\
\text { surface }\end{array}$ \\
\hline Alysiinae & & P 0.019 & P 0.001 & P 0.01 & Alysiinae & & P 0.001 & P 0.006 & P 0.021 \\
\hline Aphidiinae & & & P 0.001 & & Aphidiinae & & P 0.025 & Р 0.09 & \\
\hline Doryctinae & P 0.005 & P 0.001 & & P 0.001 & Doryctinae & P 0.037 & P 0.022 & & P 0.022 \\
\hline Euphorinae & & & P 0.003 & & Euphorinae & & & P 0.018 & \\
\hline
\end{tabular}

$\mathrm{P}$ values that resulted significant in both years $(\mathrm{P} \leq 0.05)$ and at least at 0.005 level in one of the years, are in bold.

\subsubsection{Subfamily Differences Among Different Management Systems}

The subfamilies Macrocentrinae, Meteorinae, Miracinae and Neonerinae were too poorly represented to allow a rational statistical approach. Among the other subfamilies, differences with statistical significance were found for Agathidinae, Alysiinae, Cheloninae, Doryctinae, and Homolobinae.

Agathidinae and Alysiinae were significantly more numerous in MD, Cheloninae in C, Homolobinae in A and Doryctinae in O (Table 6A).

Table 6. Results of Kruscal Wallis analysis of variance for ranks. Df $=2, \mathrm{~N}=$ number of cases in the combined samples. Only subfamilies with significative differences across the three vineyards are reported (A 2012, B 2013)

Table 6A.

\begin{tabular}{|c|c|c|c|c|c|c|c|}
\hline \multicolumn{5}{|l|}{2012} & \multicolumn{3}{|c|}{ Ranks mean } \\
\hline Subfamily & Guild & $\mathbf{N}$ & KW value & P-value & MD & $\mathrm{C}$ & $\mathbf{O}$ \\
\hline Agathidiinae & KL & 9 & 11.26 & $<0.01$ & $21.06 \mathrm{a}$ & $11.84 \mathrm{~b}$ & $9.12 b$ \\
\hline Cheloninae & $\mathrm{KL}$ & 9 & 9.45 & $<0.01$ & $8.5 \mathrm{a}$ & $19.95 b$ & $13.56 \mathrm{ab}$ \\
\hline Homolobinae & KL & 9 & 8.56 & $<0.02$ & $19.45 \mathrm{a}$ & $8.5 b$ & $14.06 \mathrm{ab}$ \\
\hline Doryctinae & IC & 9 & 12.71 & $<0.01$ & $10.56 \mathrm{a}$ & $9.78 \mathrm{a}$ & $21.67 b$ \\
\hline Alysiinae & KD & 9 & 8.71 & $<0.02$ & $20.34 \mathrm{a}$ & $11.34 \mathrm{~b}$ & $10.34 \mathrm{~b}$ \\
\hline
\end{tabular}


Table 6B.

\begin{tabular}{|c|c|c|c|c|c|c|c|}
\hline \multicolumn{5}{|l|}{2013} & \multicolumn{3}{|c|}{ Ranks mean } \\
\hline Subfamily & Guild & $\mathbf{N}$ & KW value & $\mathbf{P}$ & MD & $\mathbf{C}$ & $\mathbf{O}$ \\
\hline Agathidiinae & $\mathrm{KL}$ & 9 & 8.96 & $<0.02$ & $21.2 \mathrm{a}$ & $8.5 b$ & $12.28 \mathrm{~b}$ \\
\hline Cheloninae & $\mathrm{KL}$ & 10 & 9.5 & $<0.01$ & $9.95 \mathrm{a}$ & $16.65 \mathrm{ab}$ & $19.97 b$ \\
\hline Doryctinae & IC & 8 & 8.96 & $<0.02$ & $10.5 \mathrm{a}$ & $8.5 \mathrm{a}$ & $18.5 \mathrm{~b}$ \\
\hline Alysiinae & $\mathrm{KD}$ & 10 & 15.4 & $<0.001$ & $24.05 \mathrm{a}$ & $13.5 \mathrm{~b}$ & $8.965 b$ \\
\hline
\end{tabular}

KW value was corrected on the base of the ties scores among groups. Different, not shared letters, indicate significant differences. $\mathrm{KL}=$ Koinobiont of Lepidoptera, $\mathrm{IC}=$ Idiobiont of Coleoptera, $\mathrm{KD}=\mathrm{Koinobiont}$ of Diptera.

\subsection{Year 2013}

\subsubsection{Abiotic Factors}

This year showed a more balanced distribution of the rains with only 30 days of drought from half June to half July (http://www.sir.toscana.it).

\subsubsection{Parasitoid Subfamily Communities}

Malaise traps captured 4,799 adults belonging to the same 17 subfamilies of 2012 . All these subfamilies were recorded in the three vineyards except for Neoneurinae, captured only in MD and C. Again, the most abundant subfamilies were Microgastrinae, Aphidinae and Alysiinae. Almost all the captures showed a drastic reduction, half number of specimens were collected in comparison with the previous year, but Homolobinae, Macrocentrinae and Meteorinae showed an increase and Neonerinae have been captured again with only two specimens representing two singleton. As in 2012, the most abundant captures were recorded in the vineyard MD (1,899 specimens), followed by $\mathrm{C}$ with 1,489 and $\mathrm{O}$ with 1,411 specimens (Table 1$)$.

\subsubsection{Braconid Communities Similarity}

As in 2012, the single trap NMDS analysis grouped the first samplings in the upper-left and the last ones in the lower-right part of the graphic (Figure 1B). Such distribution is supported by Permanova main test, which found significant differences for the factors "Trap" and "Time", without significant interaction (Table 2 B). The NMDS performed on the data of the two traps joined together showed two main grouping at the similarity level of $66 \%$. On the left part of the figure are located all the MD samples and only those of $\mathrm{O}$ and $\mathrm{C}$ collected in the first period of the research; on the right side of the figure there are the samples of $\mathrm{O}$ and $\mathrm{C}$ collected in the second period (Figure 2B).

Permanova analysis confirmed the samples distribution of NMDS, showing significant differences due to the factor 'vineyard' as well as to the factor 'period'. No significant interaction resulted between the two factors (Table 3B). The pair-wise test divided MD vineyard from $\mathrm{C}$ and $\mathrm{O}$ (Table 4B).

\subsubsection{Subfamilies Similarity Contribution}

The average Bray-Curtis similarity across the vineyard sample group, ranged from 71.01(C) and 67.27 (O). The Microgastrinae headed the average similarity in $\mathrm{C}$ and $\mathrm{O}$, but Alysiinae gave the main similarity contribution in MD. Further contributes in typifying $\mathrm{C}$ are given by Alysiinae, Braconinae and Aphidiinae.

Microgastrinae, Aphidiinae and Agathidinae contributed in typifying MD, whereas Braconinae, Cheloninae, and Alysiinae contributed for $\mathrm{O}$.

As regards the analysis of the dissimilarity between all pairs of the group samples, Aphidiinae, Agathidinae, Alysiinae and Euphorinae are the most discriminating subfamilies for the pairs MD, C. Homolobinae, Euphorinae and Aphidiinae contribute in discriminating $\mathrm{C}$ vs $\mathrm{O}$, Alysiinae, Aphidiinae, Euphorinae and Agathidiinae contributed in the dissimilarity of MD vs O (Appendix F).

The simper performed on the base of the 'time' factor sample groups $(1-10)$, again gave similarity average values that resulted higher for the first weeks if confronted with the second part of the year.

Alysiinae represented the most typifying subfamily with regard to the first three weeks while Microgastrinae headed the top of the list for the remaining dates. 
As in 2012, the average dissimilarity values progressively decreased in 2013 when the dates of the samples were progressively closer to each other (Appendix G).

\subsubsection{Habitat Variables and Population Correlation}

The presence of herbs was significantly related to the abundance of Alisyiinae, and Euphorinae, whereas trees and bushes abundance and surface covered by grapevine resulted positively correlated with abundance of Doryctinae (Table 5).

\subsubsection{Subfamily Differences Among Different Vineyards}

Significative differences were found for Agathidinae, Cheloninae, Doryctinae, and Microgastrinae. The number of Agathidinae and Alysiinae was significantly higher in MD, Cheloninae and Doryctinae in O (Table 6B).

\section{Discussion}

A number of studies have pointed out the importance of the habitat management to maintain and/or increase agro-ecosystem biodiversity and to enhance biological control of arthropod pests (Risch, Andow, \& Altieri, 1983; Sheehan, 1986; Howarth 1991; Altieri, 1999; Landis, Wratten, \& Gurr, 2000; Burgio \& Sommaggio, 2007; Chong, D’Alberto, Thomson, \& Hoffman, 2010; Santos, Raimundo, Bento, \& Pereira, 2012). Unfortunately, research on natural enemy diversity conducted at the habitat scale is scarce (Fraser, Dytham, \& Mayhew, 2007) and are mostly focused on the complex of predators or parasitoids of a small number of insect pests (Altieri, Cure, \& Garcia, 1993; Menalled, Marino, Gace, \& Landis, 1999).

In this paper we tried to focus on a particular taxon (Braconidae), independently by the considerations of the pests.

Results of our study are consistent with the hypothesis that the braconid subfamily community represents a suitable indicator to characterize a vineyard. They summarize many of the attributes required for a reliable group of bioindicators (Büchs, 2003), showing good efficiency in discriminating different environments and giving good perspectives for further biodiversity studies.

The positioning of two Malaise traps, respectively in the central and in the marginal part of the experimental plot, allowed a more complete description of braconid populations occurring in the area. This consideration clearly emerges when the figures of each pair of traps are joined together confirming the observations of Fraser. Dytham and Mayhew (2008), which record an higher spatial variability when the collections of the single traps are analyzed separately. The use along many consecutive weeks increases trap suitability to describe the turn-over and the variation of braconid populations, as reported for Ichneumonidae (Fraser, Dytham, \& Mayhew, 2007; 2008). The total number of braconids captured in $2012(8,356)$ was approximately double of that obtained in $2013(4,799)$, but the same subfamilies were represented in both years with about the same proportion among themselves. In our opinion such a situation describes a well-established insect community, well integrated with the surrounding environments. The fluctuation of insect populations through time and space represent a frequent phenomenon that can be influenced by many ecological factors. Though in 2013 almost all the subfamilies showed a strong numerical reduction, Homolobinae, Meteorinae and Macrocentrinae (not much represented in 2012), increased their total number. The same number of Neoneurinae was captured in both years, but with only two specimens. It is not clear if this would be connected to the unsuitability of Malaise traps to intercept adults of this subfamily or if it would depend on the peculiar biology of this subfamily, which is strictly linked to the presence of the ants, their unique hosts (Shaw, 1997).

Our braconid captures appear quite large if compared with other studies carried out in more natural ecosystems, such as a secondary broad-leaved forest ecosystem of Western Arkansas (Lewis \& Whitefield 1999), an oak-sessile forest in Turkey (Papp, 1994) or a mountain old growth forest in Spain (Arnan, Bosch, Comas, Garcia, \& Retana, 2011).

In both years we have registered the lowest number of captures in $\mathrm{O}$, whose size is much smaller but is the most similar to a natural ecosystem. However, this is consistent with the assertion of LaSalle (1993) "... In natural situations, parasitic Hymenoptera are often present in high species number and low population size". The highest number of specimens was always collected in the vineyard MD, characterized by a higher abundance of a broad layer of herbs and where captures were dominated by Aphidiinae, Alisyiinae and Microgastrinae. Consistently, such subfamilies resulted correlated to the herbs abundance (Table 6). Based on abundance and subfamily diversity, the braconid community found in $\mathrm{C}$ does not appear to be particularly affected by the insecticide control continuously performed in the last seven years. This situation probably reflects the richness of diverse natural habitats that the surrounding areas and landscape matrix can offer, where beneficials find refuge and perform spillover during the season, increasing the pest control services across time (Macfayden, Craze, 
Polaszek, Van Achterberg, \& Memmott, 2013). These data warn against assessing the biodiversity level of an agro-ecosystem only on the base of the pest management strategies adopted. Indeed, the surrounding areas, as well as the landscape matrix, can play a major role in determining the establishment of a rich and differentiated insect population in a vineyard.

The adoption of a multivariate analysis approach well describes the temporal and spatial differences among the three vineyards, and confirms the statements of Timms, Bowden, Summerville, and Buddle (2013) about the taxonomic sufficiency concept, related to the terrestrial arthropod biodiversity. In fact, the natural environmental variables can affect the community structure by replacing species whose occurrence across the sites can be due to a random event, confusing the graphical representation. The choice of considering the insects at a higher taxon level (subfamilies versus species) reduces these nuisance effects (Clarke \& Warwick, 2001).

The higher similarity of the braconid populations during the first period of the research in comparison with the second period depends, in our opinion, by the specific behavior of our parasitoids and by the environmental conditions occurring in the three vineyards and in their surrounding areas. It is known that, after the emergence, an adult parasitoid spends its first days of life searching for places hosting potential hosts (the habitat host location phase) (Vinson, 1998). Then, during the season, parasitoids progressively reduce the spatial range of the searching behavior, limiting their movements to the habitats that ensure the most favorable foraging conditions (Alphen \& Jerwis, 1996). We assume that the highest concentration of parasitoids occurs in the vineyards in the first part of the collection period, due to the coexistence of univoltine adult species with the first flight of multivoltine species. During the spring season, braconids could have performed an higher spillover rate through the different vineyards and the surrounding areas, all nested in the same landscape matrix, contributing in this way to reduce the differences among the three sites. In this period all the sites showed a higher similarity due to the contribution of the rains, which allowed a homogeneous development of herbs everywhere. Such observation is supported by the Simper analysis that indicates Alysiinae, Aphidiinae and Microgastrinae as the most frequent subfamilies in the first period in 2012 and in 2013 and that resulted correlated to the herbs abundance in both, or at least, in one year at 0.001 level of significance. As regards the differences of each subfamily among the three vineyards, interesting considerations emerge by focusing on their life histories and guilds. The statistically higher number of Doryctinae captured in $\mathrm{O}$ (Tables 6A and 6B) diverged from the trend of the total captures, that showed the lowest number of braconids in the same vineyard. But most of Doryctinae live as idiobiont ectoparasitoids of wood-boring beetle larvae and only a few live on stem boring larvae of Lepidoptera or sawfly. Presence of wood species and woody areas on the borders of the vineyards, as well as the same grapevine plants, could have represented an useful habitat for the needs of this subfamily members (Loni, Spooner, \& Lucchi, 2012). This observation well matches with the results emerged by the multiple regression analysis, that found a significant correlation between Doryctinae, wood plants and grapevine abundance (Table 6). Similarly, the statistically higher population of Alysiinae in MD vineyard could be associated to its extended ruderal vegetation, which represents the main habitat resource for their host. Alysinae live as koinobiont endoparasitoid of cyclorrhaphous Diptera, whose larvae feed on decaying substrates or on vegetal tissues as leaf or stem-mining phytophagous (Wharton, 1997b). The differences found for these subfamilies distribution clearly rely on the habitat variables, which structurally characterize the vineyards during the period of the observations. If we consider the subfamilies Braconinae, Euphorinae, Helconinae and Opiinae, even well represented in our samples, the highest values of their captures appear randomly distributed among the vineyards (Appendices B and C) and they do not result correlated to any habitat variables. Indeed, they represent various guilds and their distribution does not seem to be linked to any particular feature of the studied areas. Braconinae are mainly idiobiont ectoparasitoids of both Lepidoptera and Coleoptera (Quicke, 1997), Euphorinae are koinobiont endoparasitoid of adults Coleoptera, but also Hymenoptera, Neuroptera, Heteroptera and Psocoptera (Shaw, 1997). Helconinae are endoparasitoid of Coleopera (Sharkey, 1997) and Opiinae are koinobiont endoparasitoid of Diptera Tephritidae and Agromyzidae (Wharton, 1997a). Different considerations could be formulated for Agathidinae, which always resulted statistically more numerous in $\mathrm{MD}$ vs $\mathrm{O}$, whereas the number of Cheloninae always resulted statistically lower in MD compared with $\mathrm{O}$ and $\mathrm{C}$. Both these subfamilies include koinobiont endophagous species of Lepidopteran larvae as well as Homolobinae, Macrocentrinae, Miracinae, Microgastrinae and Rogadinae. All these subfamilies, with exception of Microgastrinae and Rogadinae in 2012, resulted less numerous in MD (Table 1) even if their rank distribution among the sites did not permit to obtain differences statistically significant by Kruskal Wallis analysis (Table 7). No one of these koinobiont of Lepidoptera (KL) subfamilies were correlated to particular habitat variables, but they shared, as well as the guild, a differentiated distribution between the vineyard $\mathrm{MD}$ versus $\mathrm{O}$ and/or $\mathrm{C}$.

Obviously it is not possible to attribute such differences to the presence of the synthetic pheromone of $L$. botrana 
in MD vineyard. However, a rich braconid community seems to enhance the resilience of the agroecosystem by counterbalancing the reduction of KL subfamilies with the increase of another of the same guild.

In conclusion, our results corroborate braconid subfamilies as good discriminants for vineyard agro-ecosystems. In our study, environmental structural components of the vineyard seem to play a dominant role in influencing their population composition in time and space, much more than the different pest management strategies adopted for several years. This appears particularly evident if the vineyard includes and is surrounded by a natural vegetation of bushes, woods and herbs which provide shelters and supply zones, where parasitoids can perform spillover during possible disturbing events. As regards a possible influence of mating disruption technique on some subfamily distribution, our work seems to open more questions than not giving answers. How and if the synthetic pheromone dispensers of L. botrana installed in MD in the 2 years could have exerted an attractive or repulsive influence on some braconid subfamilies is not possible to confirm with our data, neither this was the goal of this paper.

\section{Acknowledgements}

We would to like to thank Dr. Piergiorgio Castellani for hosting our surveys in his farm of Crespina (Pisa) and for partially supporting the research.

\section{References}

Achterberg, C. Van. (1993). Illustrated key to the subfamily of the Braconidae (Hymenoptera: Ichneumonoidea). Zool. Verh. Leiden., 283, 1-189.

Alphen, J. J. M. Van., \& Jerwis, M. A. (1996). Foraging behaviour. In M. Jerwis \& N. Kidd (Eds.), Insect natural enemies (pp. 1-62). London, UK: Chapman \& Hall.

Altieri, M. A., Cure, J. R., \& Garcia, M. A. (1993). The role and enhancement of parasitic Hymenoptera biodiversity in agroecosystems. In J. La Salle \& I. Gauld (Eds.), Hymenoptera and biodiversity (pp. 257-275). Wallingford, UK: CAB International.

Altieri, M. A. (1999). The ecological role of biodiversity in agroecosystems. Agric. Ecosyst. Environ., 74, 19-31. http://dx.doi.org/10.1016/S0167-8809(99)00028-6

Anderson, M. J., Gorley, R. N., \& Clarke, K. R. (2008). Permanova + for Primer: Guide to Software and Statistical Methods. Plymouth, UK: Primer-E.

Anderson, A., McCormack, S., Helden, A., Sheridan, H., Kinsella, A., \& Purvis, G. (2011). The potential of parasitoid Hymenoptera as bioindicators of artropod diversity in agricultural grassland. J. Appl. Ecol., 48(2), 382-390. http://dx.doi.org/10.1111/j.1365-2664.2010.01937.x

Arakaki, N., Yamazawa, H., \& Wakamura, S. (2011). The egg parasitoid Telenomus euproctidis (Hymenoptera: Scelionidae) uses sex pheromone released by immobile female tussock moth Orgya postica (Lepidoptera: Lymantridae). Appl. Entomol. Zool., 46, 195-200. http://dx.doi.org/10.1007/s13355-011-0031-4

Arnan, X., Bosch, J., Comas, L., Gracia, M., \& Retana, J. (2011). Habitat determinants of abundance, structure and composition of flying Hymenoptera communities in mountain old-growth forests. Insect Conserv. Diver., 4, 200-211. http://dx.doi.org/10.1111/j.1752-4598.2010.00123.x

Askew, R. R., \& Shaw, R. M. (1986). Parasitoid community: their size, structure and development. In J. Waage \& D. J. Greathead (Eds.), Insect Parasitoids (pp. 225-264). London, UK: Academic Press.

Bentley, W. J., Varela, L., \& Daare, K. M. (2005). Grapes, insect ecology and control. In D. Pimentel (Ed.), Encyclopedia of pest management (pp. 1-8). New York: Taylor \& Francis.

Büchs, W. (2003). Biodiversity and agri-environmental indicators-general scopes and skills with special reference to the habitat level. Agr. Ecosyst. Environ., 98, 35-78. http://dx.doi.org/10.1016/S0167-8809(03)00070-7

Burgio, G., \& Sommaggio, D. (2007). Syrphids as landscape bioindicators in Italian agroecosystems. Agr. Ecosyst. Environ., 120, 416-422. http://dx.doi.org/10.1016/j.agee.2006.10.021

Chong, C. S., D'Alberto, C. F., Thomson, L. J., \& Hoffmann, A. A. (2010). Influence of native ants on arthropod communities in a vineyard. Agr. Forest Entomol., 12, 223-232.

Clarke, K. R., \& Warwick, R. M. (2001). Change in marine communities: An approach to statistical analysis and interpretation (2nd ed.). Plymouth, UK: Primer-E.

Clarke, K. R., \& Warwick, R. M. (2006). PRIMER v6, User manual/tutorial. Plymouth, UK: Primer-E. 
Ent Van Der, J. L., \& Shaw, R. S. (1998). Species richness of Costa Rican Cenocoeliini (Hymenoptera: Braconidae): a latitudinal and altitudinal search for anomalous diversity. J. Hymenopt. Res., 7(1), 15-24.

Fraser, M. E. S., Dytham, C., \& Mayhew, J. P. (2007). Determinants of parasitoid abundance and diversity in woodland habitats. J. Appl. Ecol., 44, 352-361. http://dx.doi.org/10.1111/j.1365-2664.2006.01266.x

Fraser, M. E. S., Dytham, C., \& Mayhew, J. P. (2008). Patterns in the abundance and distribution of ichneumonid parasitoids within and across habitat patches. Ecol. Entomol., 33, 473-483. http://dx.doi.org/10.1111/j.1365-2311.2008.00992.x

Gonzales, D. H., \& Ruíz, B. D. (2000). Los Braconidos (Hymenoptera: Braconidae) como grupo parametro de biodiversidad en las selvas deciduas del tropico: una discusion acerca de su posible uso. Acta Zoologica Mexicana, 79, 43-56.

Hoback, W. W., Svatos, M. T., Spomer, M. S., \& Higley, G. L. (1999). Trap colour and placement affects estimates of insect family-level abundance and diversity in a Nebraska salt marsh. Ent. Exp. Appl., 91, 393-402. http://dx.doi.org/10.1046/j.1570-7458.1999.00507.x

Howarth, F. G. (1991). Environmental impacts of classical biological control. Ann. Rew. Entomol., 36, 485-509. http://dx.doi.org/10.1146/annurev.en.36.010191.002413

Landis, A. D., Wratten, D. S., \& Gurr, M. G. (2000). Habitat management to conserve natural enemies of artropod pests in agriculture. Ann. Rew. Entomol., 45, 175-201. http://dx.doi.org/10.1146/annurev.ento.45.1.175. PMid:10761575

Langhof, M., Meyhöfer, R., Poehling, H. M., \& Gathmann, A. (2005). Measuring the field dispersal of Aphidius colemani (Hymenoptera: Braconidae). Agr. Ecosyst. Environ., 107, 137-143. http://dx.doi.org/10.1016/j.agee.2004.12.001

LaSalle, J., \& Gauld, I. D. (1991). Parasitic Hymenoptera and biodiversity crisis. Redia., 74(3), 315-334.

LaSalle, J. (1993). Parasitic Hymenoptera, Biological control and biodiversity. In J. LaSalle \& I. Goldon (Eds.), Hymenoptera and biodiversity (pp. 197-215). CAB, Wallingford, Oxon, UK.

Lévesque-Beaudin, V., \& Wheeler, T. A. (2011). Spatial scale and nested patterns of beta-diversity in temperate forest Diptera. Insect Conserv. Diver., 4, 284-296. http://dx.doi.org/10.1111/j.1752-4598.2010.00127.x

Lewis, C. N., \& Whitefield, J. B. (1999). Braconid wasps (Hymenoptera: Braconidae). Diversity in forest plots under different silvicultural methods. Environ. Entomol., 28(6), 986-997.

Loni, A., \& Lucchi, A. (2012). Preliminary study on the suitability of Hymenoptera: Braconidae as bioindicators of the pest management system in the vineyards. IOBC wprs Bulletin, Bullettin OILB srop., 75, 119-122.

Loni, A., Spooner, R. H., \& Lucchi, A. (2012). First record of Zombrus bicolor (Enderlein) (Hymenoptera, Braconidae, Doryctinae) in Western Europe. Zookeys., 219, 87-91. http://dx.doi.org/10.3897/zookeys.219.3439PMid:22977352 PMCid:PMC3433699

Macfayden, S., Craze, P. G., Polaszek, A., Van Achterberg, K., \& Memmott, J. (2013). Parasitoid diversity reduces the variability in pest control services across time on farms. Prod. R. Soc. B. http://dx.doi.org/10.1098/rspb.2010.2673. http://dx.doi.org/10.1098/rspb.2010.2673

Maeto, K., Noerdjito, W. A., Belokobylskij, A. S., \& Fukuyama, K. (2009). Recovery of species diversity and composition of braconids parasitic wasp after reforestation of degraded grasslands in East Kalimantan. $J$. Insect Conserv., 13, 245-257. http://dx.doi.org/10.1007/s10841-008-9164-3

Maleque, A. M. D., Maeto, K., Machino, S., Goto, H., Tanaka, H., Hasegawa, M., \& Miyamoto, A. (2010). A cronosequence of understorey parasitic wasp assemblages in secondary broad-leaved forests in a Japanese "satoyama" landscape. Insect Conserv. Diver., 3, 143-151. http://dx.doi.org/10.1111/j.1752-4598.2010.00087.x

Marini, L., Öckinger, E., Battisti, A., \& Bommarco, R. (2012). High mobility reduces beta-diversity among orthopteran communities - implications for conservation. Insect Conserv. Diver., 5, 37-45. http://dx.doi.org/10.1111/j.1752-4598.2011.00152.x

Menalled, F. D., Marino, P. C., Gage, S. H., \& Landis, A. D. (1999). Does agricultural landscape structure affect parasitism and parasitoid diversity? Ecol. Appl., 9(2), 634-641. http://dx.doi.org/10.1890/1051-0761(1999)009[0634:DALSAP]2.0.CO;2

Papp, J. (1994). The dispersion of Braconid wasps on an oak forest of Hungary (Hymenoptera: Braconidae). 
Folia Entomologica Hungarica, 55, 305-320.

Quicke, J. D. L. (1997). Subfamily Braconinae. In A. E. Wharton, M. P. Marsh \& J. M. Sharkey (Eds.), Manual of new world genera of the family Braconidae (Hymenoptera) (pp. 149-174). The International Society of Hymenopterist, Washington, DC.

Risch, S. J., Andow, D., \& Altieri, M. A. (1983). Agroecosystem diversity and pest control: data, tentative conclusion and new research directions. Environ. Entomol., 12(3), 625-629.

Santos, A. M. C., Jones, O. R., Quicke, D. L. J., \& Hortal, J. (2010). Assessing the reliability of biodiversity databases: identifying evenly inventoried island parasitoid faunas (Hymenoptera: Ichneumonoidea) worldwide. Insect Conserv. Diver., 3, 72-82. http://dx.doi.org/10.1111/j.1752-4598.2010.00079.x

Santos, A. M. C., \& Quicke, D. L. J. (2011). Large-scale diversity patterns of parasitoid insects. Entomol. Sci., 14, 371-382. http://dx.doi.org/10.1111/j.1479-8298.2011.00481.x

Santos, S. A. P., Raimundo, A., Bento, A., \& Pereira, A. J. (2012). Species abundance patterns of coccinellid communities associated with olive, chestnut and almond crops in north-eastern Portugal. Agr. Forest Entomol., 14, 376-382. http://dx.doi.org/10.1111/j.1461-9563.2012.00578.x

Scarratt, S. L., Wratten, S. D., \& Shishehbor, P. (2008). Measuring parasitoid movement from floral resources in a vineyard. Biol. Control, 46, 107-113. http://dx.doi.org/10.1016/j.biocontrol.2008.03.016

Sharkey, J. M. (1997). Key to new world subfamilies of the family Braconidae. In A. E. Wharton, M. P. Marsh, and J. M. Sharkey (Eds.), Manual of new world genera of the family Braconidae (Hymenoptera) (pp. 39-63). Washington, DC:The international society of hymenopterist.

Sharkey, J. M. (1997b). Subfamily Helconinae. In A. E. Wharton, M. P. Marsh, \& J. M. Sharkey (Eds.). Manual of new world genera of the family Braconidae (Hymenoptera) (pp. 260-272). The international society of hymenopterist, Washington, DC.

Shaw, R. S. (1997). Subfamily Euphorinae. In A. E. Wharton, M. P. Marsh \& J. M. Sharkey (Eds.). Manual of new world genera of the family Braconidae (Hymenoptera) (pp. 235-254). Washington, DC: The international society of hymenopterist.

Shaw, R. M., \& Hochberg, E. M. (2001). The neglect of parasitic Hymenoptera in insects conservation strategies: The British fauna as a prime example. J. Insects Conserv., 5, 252-263. http://dx.doi.org/10.1023/A:1013393229923

Shaw, R. M. (2006). Habitat considerations for parasitic wasps (Hymenoptera). J. Insects Conserv., 10, $117-127$. http://dx.doi.org/10.1007/s10841-006-6288-1

Sheenan, W. (1986). Response by specialist and generalist natural enemies to agroecosystem diversification: a selective review. Environ. Entomol., 15(3), 456-461.

Siegel, S., \& Castellan, J. N. (1988). Nonparametric statistic for the behavioural science (2nd ed.). New York: McGraw-Hill, Book Company.

Stenbacka, F., Hjälté, J., Hilszczański, J., Ball, P. J., Gibb, H., Johansson, T., .. Danell, K. (2010). Saproxylic parasitoid (Hymenoptera, Ichneumonoidea) communities in managed boreal forest landscapes. Insect Conserv. Diver., 3, 114-123. http://dx.doi.org/10.1111/j.1752-4598.2010.00082.x

Thomson, J. L., \& Hoffmann, A. A. (2009). Vegetation increases the abundance of natural enemies in vineyards. Biol. Control., 49, 259-269. http://dx.doi.org/10.1016/j.biocontrol.2009.01.009

Timms, L. L., Bowden, J. J., Summerville, K. S., \& Buddle, C. M. (2013). Does species-level resolution matter? Taxonomic sufficiency in terrestrial arthropod biodiversity studies. Insect Conserv. Diver., 6, 453-462. http://dx.doi.org/10.1111/icad.12004

Tompkins, J. M., Wratten, S. D., \& Simpson, M. (2012). Enhancing Ecosystem Services in Australasian Vineyards for Sustainability and Profit. In N. J. Bostanian et al. (Eds.), Arthropod Management in Vineyards: Pests, Approaches, and Future Directions (pp. 139-157). Springer Science + Business Media. http://dx.doi.org/10.1007/978-94-007-4032-7_7

Tscharntke, T., Tylianakis, J. M., Rand, T. A., Didham, R. K., Fahrig, L., Batáry, P., ... Westphal, C. (2012). Landscape moderation of biodiversity patterns and processes - eight hypotheses. Biol. Rev., 87, 661-685. http://dx.doi.org/10.1111/j.1469-185X.2011.00216.xPMid:22272640

Veijalainen, A., Sääksjärvi, I. E., Erwin, T. L., Gomez, I. C., \& Longino, J. T. (2012). Subfamily composition of 
Ichneumonidae (Hymenoptera) from western Amazonia: Insights into diversity of tropical parasitoid wasps. Insect Conserv. Diver. http://dx.doi.org/10.1111/j.1752-4598.2012.00185

Vincent, C., Isaacs, R., \& Bostanian, N. J. (2012). Principles of Arthropod Pest Management in Vineyards. In Bostanian et al. (Eds.), Arthtopod Management in Vineyards: Pests, Approaches, and Future Directions (pp. 1-17). Springer Science + Business Media. http://dx.doi.org/10.1007/978-94-007-4032-7_1

Vinson, S. B. (1998). The general host selection behavior of parasitoid Hymenoptera and a comparison of initial strategies utilized by larvaphagous and oophagous species. Biol. Control., 11, 79-96. http://dx.doi.org/10.1006/bcon.1997.0601

Wanner, H., Gu, H., Hattendorf, B., Günther, D., \& Dorn, S. (2007). Tracking parasitoids with the stable isotope $44 \mathrm{Ca}$ in agroecosystems. Agricul. Ecosys. Environ., 118, 143-148. http://dx.doi.org/10.1016/j.agee.2006.05.005

Wharton, R. A. (1993). Bionomics of Braconidae. Annu. Rev. Entomol., 38, 121-143. http://dx.doi.org/10.1146/annurev.ento.38.1.121

Wharton, R. A. (1997a). Introduction. In A. E. Wharton, M. P. Marsh \& J. M. Sharkey (Eds.), Manual of new world genera of the family Braconidae (Hymenoptera) (pp. 1-15). Washington, DC: The international society of hymenopterist.

Wharton, R. A. (1997b). Subfamily Alisiinae. In A. E. Wharton, M. P. Marsh \& J. M. Sharkey (Eds.), Manual of new world genera of the family Braconidae (Hymenoptera) (pp. 85-101). Washington, DC: The international society of hymenopterist.

Whitefield, J. B., \& Lewis, N. C. (2001). Analytical survey of the Braconid wasp fauna (Hymenoptera: Braconidae) on six Midwestern U.S. tall grass prairies. Ann. Entom. Soc. Am., 94(2), 230-238. http://dx.doi.org/10.1603/0013-8746(2001)094[0230:ASOTBW]2.0.CO;2 


\section{Appendix}

Appendix A. Habitat variables pooled for the circular area around each trap

\begin{tabular}{|c|c|c|c|c|c|}
\hline $\begin{array}{l}\text { Vineyrad } \\
\text { samples }\end{array}$ & Vineyard surface $\left(\mathrm{m}^{2}\right)$ & Trees number & Bushes number & $\begin{array}{l}\text { Herbs surface }\left(\mathrm{m}^{2}\right) \\
2012\end{array}$ & $\begin{array}{c}\text { Herbs surface }\left(\mathrm{m}^{2}\right) \\
2013\end{array}$ \\
\hline $\mathrm{C} 1$ & 12500 & 14 & 28 & 5543 & 9572 \\
\hline MD1 & 14500 & 46 & 24 & 9220 & 11304 \\
\hline $\mathrm{O} 1$ & 6500 & 60 & 45 & 5120 & 11461 \\
\hline $\mathrm{C} 2$ & 12500 & 14 & 28 & 4492 & 8635 \\
\hline MD2 & 14500 & 46 & 24 & 8480 & 10990 \\
\hline $\mathrm{O} 2$ & 6500 & 60 & 45 & 4132 & 10205 \\
\hline $\mathrm{C} 3$ & 12500 & 14 & 28 & 3510 & 4710 \\
\hline MD3 & 14500 & 46 & 24 & 7020 & 8635 \\
\hline $\mathrm{O} 3$ & 6500 & 60 & 45 & 2970 & 10205 \\
\hline $\mathrm{C} 4$ & 12500 & 14 & 28 & 2520 & 3140 \\
\hline MD4 & 14500 & 46 & 24 & 6480 & 7065 \\
\hline $\mathrm{O} 4$ & 6500 & 60 & 45 & 2550 & 6280 \\
\hline C5 & 12500 & 14 & 28 & 2000 & 2669 \\
\hline MD5 & 14500 & 46 & 24 & 6020 & 6594 \\
\hline O5 & 6500 & 60 & 45 & 1490 & 5495 \\
\hline $\mathrm{C} 6$ & 12500 & 14 & 28 & 1490 & 2355 \\
\hline MD6 & 14500 & 46 & 24 & 6000 & 6280 \\
\hline O6 & 6500 & 60 & 45 & 1040 & 4710 \\
\hline C7 & 12500 & 14 & 28 & 1040 & 3140 \\
\hline MD7 & 14500 & 46 & 24 & 5490 & 7065 \\
\hline O7 & 6500 & 60 & 45 & 820 & 5495 \\
\hline $\mathrm{C} 8$ & 12500 & 14 & 28 & 1000 & 3925 \\
\hline MD8 & 14500 & 46 & 24 & 6010 & 7536 \\
\hline O8 & 6500 & 60 & 45 & 990 & 5809 \\
\hline C9 & 12500 & 14 & 28 & 1100 & 4710 \\
\hline MD9 & 14500 & 46 & 24 & 6550 & 7850 \\
\hline O9 & 6500 & 60 & 45 & 1220 & 6280 \\
\hline $\mathrm{C} 10$ & 12500 & 14 & 28 & - & 8635 \\
\hline MD10 & 14500 & 46 & 24 & - & 10362 \\
\hline O10 & 6500 & 60 & 45 & - & 9420 \\
\hline
\end{tabular}

C (Conventional), MD (Mating disruption), O (Organic). Numbers represent progressive dates of samples collection. Variables "Vineyard surface", "Trees number" and "Bushes number" are not changed through the years. 
Appendix B. Captures of Braconidae subfamilies, subdivided for progressive sample dates (1-9), and vineyard C (Conventional), Md (Mating disruption), O (Organic)

\begin{tabular}{|c|c|c|c|c|c|c|c|c|c|c|c|c|c|c|c|c|c|c|c|c|c|c|c|c|c|c|c|c|}
\hline \multicolumn{29}{|c|}{2012} \\
\hline Date & 1 & & & 2 & & & 3 & & & 4 & & & 5 & & & 6 & & & 7 & & & 8 & & & 9 & & & \\
\hline Site & $\mathrm{C}$ & MD & 0 & $\mathrm{C}$ & MD & 0 & $\mathrm{C}$ & MD & 0 & $\mathrm{C}$ & MD & 0 & $\mathrm{C}$ & MD & 0 & $\mathrm{C}$ & MD & 0 & C & MD & 0 & $\mathrm{C}$ & MD & 0 & $\mathrm{C}$ & MD & 0 & Total \\
\hline \multicolumn{29}{|c|}{ Subfamily } \\
\hline Ag & & 3 & & & 5 & 4 & 4 & 14 & 7 & 21 & 24 & 1 & 2 & 27 & 2 & 12 & 79 & & 12 & 44 & 2 & 5 & 7 & & 1 & 9 & 5 & 290 \\
\hline Al & 34 & 79 & 40 & 86 & 109 & 36 & 69 & 95 & 127 & 14 & 184 & 7 & 2 & 23 & 2 & 3 & 62 & 3 & 5 & 52 & & 3 & 15 & 2 & 5 & 77 & 9 & 1143 \\
\hline Aph & 161 & 303 & 114 & 228 & 591 & 141 & 45 & 29 & 93 & 8 & 19 & 4 & 1 & 1 & 1 & & 8 & & 1 & 4 & & & & & & 18 & 3 & 1773 \\
\hline $\mathrm{Br}$ & 11 & 5 & 9 & 21 & 24 & 16 & 36 & 21 & 39 & 28 & 44 & 13 & 17 & 9 & 6 & 23 & 9 & 6 & 27 & 5 & 7 & 15 & 3 & 4 & 31 & 3 & 12 & 444 \\
\hline Ch & 4 & 1 & 4 & 35 & 4 & 6 & 112 & 11 & 38 & 65 & 25 & 59 & 30 & 6 & 12 & 35 & 12 & 17 & 60 & 4 & 7 & 25 & 5 & 6 & 14 & 9 & 13 & 619 \\
\hline Do & & 3 & 2 & 5 & 13 & 6 & 2 & & 15 & & 4 & 11 & 1 & & 4 & & & 11 & 1 & 1 & 7 & & & 14 & 1 & & 8 & 109 \\
\hline Eu & 16 & 57 & 32 & 53 & 153 & 48 & 63 & 28 & 50 & 22 & 58 & 6 & 9 & 17 & 3 & 4 & 17 & 4 & 1 & 5 & 4 & 1 & 2 & 4 & & 1 & 4 & 662 \\
\hline He & 24 & 9 & 4 & 41 & 46 & 25 & 23 & 2 & 8 & 3 & 8 & & 5 & 3 & 3 & 1 & & 3 & 5 & 1 & & 1 & & & & 4 & & 219 \\
\hline Hom & 16 & 7 & 7 & 3 & 1 & 2 & 14 & 1 & 5 & 10 & 2 & 9 & 3 & & 3 & 15 & 7 & 10 & 13 & 7 & 11 & 1 & 2 & 3 & 18 & & 7 & 177 \\
\hline Hor & 2 & 2 & & 2 & 3 & 1 & 12 & 1 & 5 & 4 & 1 & 2 & 1 & 2 & 3 & & 3 & 1 & 1 & 2 & & 2 & 4 & & 1 & 1 & 1 & 57 \\
\hline Mac & 2 & 1 & & 2 & & & 2 & & & & & & 1 & & & 1 & & & 1 & 1 & & & & & & 1 & & 12 \\
\hline Met & & 1 & & & & & 2 & & 1 & & & & & & & & & & & & & & & & & & & 4 \\
\hline Mig & 20 & 14 & 25 & 103 & 101 & 53 & 226 & 76 & 206 & 118 & 182 & 146 & 19 & 89 & 54 & 39 & 139 & 70 & 110 & 126 & 62 & 30 & 60 & 19 & 53 & 55 & 45 & 2240 \\
\hline Mir & & & 1 & & & & & & & & & & & & & 2 & & 10 & 4 & & 4 & 11 & & 9 & & & & 41 \\
\hline $\mathrm{Ne}$ & & & & & & & & & & & & & & & & & 1 & & & 1 & & & & & & & & 2 \\
\hline Op & 3 & 7 & 2 & 46 & 9 & 18 & 29 & 12 & 21 & 6 & 37 & 6 & 3 & 16 & & 3 & 2 & & 2 & 5 & 1 & 1 & 4 & 1 & 3 & 12 & 1 & 250 \\
\hline Ro & 2 & 3 & 6 & 7 & 1 & 4 & 46 & 8 & 45 & 17 & 19 & 9 & 13 & 14 & 6 & 14 & 34 & 6 & 9 & 17 & 4 & 3 & 13 & 3 & 2 & 5 & 4 & 314 \\
\hline Total & 295 & 495 & 246 & 632 & 1060 & 360 & 685 & 298 & 660 & 316 & 607 & 273 & 107 & 207 & 99 & 152 & 373 & 141 & 252 & 275 & 109 & 98 & 115 & 65 & 129 & 195 & 112 & 8356 \\
\hline
\end{tabular}


Appendix C. Captures of Braconidae subfamilies, subdivided for progressive sample dates (1-10), and vineyard $\mathrm{C}$ (Conventional), MD (Mating disruption), O (Organic)

\begin{tabular}{|c|c|c|c|c|c|c|c|c|c|c|c|c|c|c|c|c|c|c|c|c|c|c|c|c|c|c|c|c|c|c|c|}
\hline \multicolumn{32}{|c|}{2013} \\
\hline Date & 1 & & & 2 & & & 3 & & & 4 & & & 5 & & & 6 & & & 7 & & & 8 & & & 9 & & & 10 & & & \\
\hline Site & C & MD & 0 & C & MD & 0 & $\mathrm{C}$ & MD & 0 & $\mathrm{C}$ & MD & 0 & $\mathrm{C}$ & MD & 0 & C & MD & 0 & $\mathrm{C}$ & MD & 0 & C & MD & 0 & C & MD & 0 & $\mathrm{C}$ & MD & 0 & Total \\
\hline \multicolumn{32}{|c|}{ Subfamily } \\
\hline Ag & & & & & 3 & 2 & 1 & 34 & & & 4 & 4 & & 5 & 2 & 1 & 7 & & & 7 & 2 & 3 & 8 & 1 & 1 & 2 & 1 & 4 & 9 & 17 & 118 \\
\hline Al & 24 & 44 & 22 & 39 & 76 & 21 & 62 & 129 & 32 & 21 & 84 & 6 & 11 & 47 & 2 & 4 & 41 & 2 & 2 & 38 & 1 & 13 & 49 & 3 & 6 & 30 & 4 & 7 & 23 & 6 & 849 \\
\hline Aph & 7 & 43 & 17 & 17 & 96 & 26 & 22 & 161 & 61 & 11 & 59 & 18 & 11 & 24 & 5 & 3 & 3 & 2 & 4 & 1 & & 3 & 12 & & 1 & 3 & & 9 & 3 & & 622 \\
\hline $\mathrm{Br}$ & 2 & 1 & 2 & 7 & 2 & 7 & 19 & 10 & 13 & 3 & 13 & 16 & 12 & 7 & 11 & 21 & 7 & 10 & 21 & 4 & 6 & 22 & 1 & 9 & 10 & 1 & 9 & 9 & 2 & 16 & 273 \\
\hline Ch & & & 1 & 1 & & 4 & 6 & 3 & 7 & 11 & 4 & 28 & 17 & 2 & 8 & 7 & 1 & 6 & 3 & 1 & 3 & 20 & 2 & 17 & 14 & 4 & 31 & 1 & 2 & 10 & 214 \\
\hline Do & & & & 1 & 1 & 1 & & 1 & 6 & 1 & 1 & 3 & & & 3 & & & 1 & & 1 & 2 & & & & 1 & & 1 & 1 & 1 & 2 & 28 \\
\hline Eu & 6 & 37 & 33 & 10 & 34 & 52 & 33 & 58 & 56 & 10 & 10 & 8 & 7 & & & 1 & 10 & & 2 & 3 & 1 & 1 & & & 1 & 4 & 1 & 3 & 2 & 1 & 384 \\
\hline $\mathrm{He}$ & 3 & 1 & 7 & 5 & 4 & 2 & 4 & 2 & 12 & 3 & 1 & 1 & 8 & 3 & 3 & 5 & 1 & 3 & 1 & 1 & & 2 & 4 & & 2 & 1 & 1 & & & & 80 \\
\hline Hom & 4 & & 1 & 3 & 1 & 3 & 3 & & & & 3 & 3 & 3 & & & 1 & 3 & 5 & 1 & 4 & 12 & 7 & 5 & 15 & 27 & 10 & 29 & 66 & 12 & 70 & 291 \\
\hline Hor & & & & & & & & & 1 & 1 & 1 & 2 & 1 & & 1 & & 2 & & 2 & 2 & & 1 & 3 & & 1 & & & 1 & & & 19 \\
\hline Mac & 3 & 1 & 2 & 1 & & 1 & 2 & & 1 & & & & 3 & & 1 & & & 1 & 3 & & & 1 & & & & & 1 & & 1 & & 22 \\
\hline Met & & 2 & & 2 & & & & 1 & & 1 & & 1 & & 1 & & & & & & & & & & & & & & & & 1 & 9 \\
\hline Mig & 17 & 13 & 15 & 31 & 21 & 25 & 36 & 79 & 41 & 29 & 49 & 58 & 29 & 52 & 73 & 47 & 58 & 51 & 71 & 51 & 61 & 128 & 48 & 58 & 168 & 34 & 71 & 65 & 28 & 57 & 1564 \\
\hline Mir & 1 & 1 & & 1 & & & & & 1 & & & & & & & & & & & & & & & & & & & 1 & & 1 & 6 \\
\hline $\mathrm{Ne}$ & & & & & & & & & & & & & & & & & & & & & & 1 & 1 & & & & & & & & 2 \\
\hline Op & & 5 & 4 & 15 & 9 & 11 & 18 & 29 & 17 & 4 & 6 & 8 & 4 & 10 & 2 & 4 & 2 & 1 & 1 & 6 & & 2 & 1 & & 1 & & 3 & 3 & 2 & 4 & 172 \\
\hline Ro & 1 & & & 2 & & 4 & 3 & 8 & 8 & 1 & 2 & 8 & 8 & 4 & 12 & 8 & 5 & 5 & 5 & 7 & 1 & 7 & 6 & 7 & 8 & 1 & 3 & 16 & 2 & 4 & 146 \\
\hline Total & 68 & 148 & 104 & 135 & 247 & 159 & 209 & 515 & 256 & 96 & 237 & 164 & 114 & 155 & 123 & 102 & 140 & 87 & 116 & 126 & 89 & 211 & 140 & 110 & 241 & 90 & 155 & 186 & 87 & 189 & 4799 \\
\hline
\end{tabular}


Appendix D.

Year 2012

SIMPER - Similarity Percentages

Subfamilies contributions

\section{Parameters}

Resemblance: Bray Curtis similarity

Cut off for low contributions: $90,00 \%$

\section{Factor Groups}

Sample Vineyard

C1 C

$\mathrm{C} 2 \mathrm{C}$

$\mathrm{C} 3 \mathrm{C}$

$\mathrm{C} 4 \mathrm{C}$

C5 $\mathrm{C}$

C6 C

C7 C

C8 C

C9 C

MD1 MD

MD2 MD

MD3 MD

MD4 MD

MD5 MD

MD6 MD

MD7 MD

MD8 MD

MD9 MD

O1 O

O2 O

O3 O

O4 O

O5 O

O6 O

O7 O

O8 O

O9 O 


\section{Group C}

Average similarity: 70,32

$\begin{array}{lrrrrl}\text { Species } & \text { Av.Abund } & \text { Av.Sim } & \text { Sim/SD } & \text { Contrib\% } & \text { Cum.\% } \\ \text { Mig } & 4,08 & 12,22 & 5,48 & 17,37 & 17,37 \\ \mathrm{Ch} & 3,47 & 10,10 & 3,43 & 14,37 & 31,74 \\ \mathrm{Br} & 3,13 & 10,09 & 5,08 & 14,35 & 46,09 \\ \mathrm{Hom} & 2,20 & 5,92 & 2,08 & 8,42 & 54,51 \\ \mathrm{Al} & 2,49 & 5,74 & 3,29 & 8,17 & 62,68 \\ \mathrm{Ro} & 2,23 & 5,67 & 2,95 & 8,06 & 70,74 \\ \mathrm{Op} & 1,84 & 4,23 & 3,41 & 6,01 & 76,75 \\ \mathrm{Eu} & 2,16 & 3,89 & 1,24 & 5,53 & 82,28 \\ \mathrm{He} & 1,83 & 3,30 & 1,30 & 4,69 & 86,97 \\ \mathrm{Ag} & 1,49 & 2,87 & 0,97 & 4,08 & 91,04\end{array}$

\section{Group MD}

Average similarity: 74,69

$\begin{array}{lrrrrl}\text { Species } & \text { Av.Abund } & \text { Av.Sim } & \text { Sim/SD } & \text { Contrib\% } & \text { Cum.\% } \\ \text { Mig } & 4,37 & 13,05 & 4,72 & 17,48 & 17,48 \\ \mathrm{Al} & 4,14 & 12,02 & 7,75 & 16,09 & 33,56 \\ \mathrm{Ag} & 2,78 & 7,20 & 3,11 & 9,64 & 43,20 \\ \mathrm{Eu} & 2,88 & 6,29 & 2,05 & 8,42 & 51,62 \\ \mathrm{Ro} & 2,32 & 6,02 & 2,13 & 8,06 & 59,68 \\ \mathrm{Op} & 2,28 & 6,01 & 3,51 & 8,05 & 67,73 \\ \mathrm{Br} & 2,34 & 5,90 & 4,89 & 7,91 & 75,64 \\ \mathrm{Ch} & 2,03 & 5,30 & 2,66 & 7,09 & 82,73 \\ \text { Aph } & 2,88 & 5,00 & 1,25 & 6,70 & 89,43 \\ \text { Hor } & 1,08 & 2,94 & 3,12 & 3,93 & 93,36\end{array}$

Group $O$

Average similarity: 70,96

$\begin{array}{lrrrrl}\text { Species } & \text { Av.Abund } & \text { Av.Sim } & \text { Sim/SD } & \text { Contrib\% } & \text { Cum.\% } \\ \text { Mig } & 4,09 & 14,15 & 5,30 & 19,94 & 19,94 \\ \text { Ch } & 2,60 & 8,21 & 3,99 & 11,56 & 31,50 \\ \text { Br } & 2,40 & 7,83 & 6,79 & 11,03 & 42,53 \\ \text { Do } & 2,15 & 7,15 & 3,08 & 10,08 & 52,61 \\ \text { Eu } & 2,34 & 6,64 & 4,45 & 9,36 & 61,97 \\ \text { Ro } & 2,02 & 6,43 & 5,69 & 9,06 & 71,02 \\ \text { Hom } & 1,89 & 6,25 & 3,02 & 8,81 & 79,83 \\ \text { Al } & 2,24 & 4,69 & 1,50 & 6,61 & 86,44 \\ \text { Aph } & 1,99 & 2,45 & 0,63 & 3,45 & 89,89 \\ \text { Op } & 1,24 & 1,98 & 1,00 & 2,79 & 92,68\end{array}$




\section{Groups $C \& M D$}

Average dissimilarity $=31,47$

$$
\text { Group C Group MD }
$$

$\begin{array}{lrrrrrl}\text { Species } & \text { Av.Abund } & \text { Av.Abund } & \text { Av.Diss } & \text { Diss/SD } & \text { Contrib\% } & \text { Cum.\% } \\ \text { Aph } & 1,99 & 2,88 & 4,16 & 1,37 & 13,22 & 13,22 \\ \mathrm{Al} & 2,49 & 4,14 & 3,25 & 1,56 & 10,31 & 23,54 \\ \mathrm{Eu} & 2,16 & 2,88 & 2,88 & 1,36 & 9,16 & 32,70 \\ \mathrm{Ag} & 1,49 & 2,78 & 2,62 & 1,42 & 8,34 & 41,04 \\ \mathrm{Ch} & 3,47 & 2,03 & 2,58 & 1,85 & 8,19 & 49,23 \\ \mathrm{He} & 1,83 & 1,46 & 2,29 & 1,40 & 7,28 & 56,51 \\ \mathrm{Hom} & 2,20 & 1,09 & 2,28 & 1,48 & 7,25 & 63,76 \\ \mathrm{Op} & 1,84 & 2,28 & 1,84 & 1,60 & 5,85 & 69,61 \\ \mathrm{Br} & 3,13 & 2,34 & 1,77 & 1,47 & 5,61 & 75,22 \\ \mathrm{Ro} & 2,23 & 2,32 & 1,63 & 1,37 & 5,18 & 80,40 \\ \text { Mig } & 4,08 & 4,37 & 1,53 & 1,50 & 4,86 & 85,26 \\ \text { Do } & 0,55 & 0,70 & 1,30 & 1,15 & 4,13 & 89,38 \\ \text { Mir } & 0,58 & 0,00 & 1,07 & 0,63 & 3,39 & 92,77\end{array}$

Groups $C \& O$

Average dissimilarity $=32,28$

$\begin{array}{lrrrrrl}\text { Group C } & \text { Group O } & & & & \\ \text { Species } & \text { Av.Abund } & \text { Av.Abund } & \text { Av.Diss } & \text { Diss/SD } & \text { Contrib\% } & \text { Cum.\% } \\ \text { Aph } & 1,99 & 1,99 & 3,94 & 1,19 & 12,20 & 12,20 \\ \text { Do } & 0,55 & 2,15 & 3,06 & 1,95 & 9,48 & 21,69 \\ \mathrm{Al} & 2,49 & 2,24 & 2,70 & 1,42 & 8,37 & 30,06 \\ \mathrm{Eu} & 2,16 & 2,34 & 2,62 & 1,57 & 8,13 & 38,19 \\ \mathrm{He} & 1,83 & 1,09 & 2,59 & 1,41 & 8,03 & 46,22 \\ \text { Op } & 1,84 & 1,24 & 2,24 & 1,53 & 6,94 & 53,16 \\ \mathrm{Ch} & 3,47 & 2,60 & 2,21 & 1,71 & 6,84 & 60,00 \\ \mathrm{Ag} & 1,49 & 0,93 & 2,12 & 1,33 & 6,58 & 66,58 \\ \text { Mir } & 0,58 & 0,78 & 1,84 & 0,96 & 5,71 & 72,29 \\ \mathrm{Br} & 3,13 & 2,40 & 1,65 & 1,57 & 5,12 & 77,42 \\ \mathrm{Ro} & 2,23 & 2,02 & 1,62 & 1,67 & 5,00 & 82,42 \\ \text { Mig } & 4,08 & 4,09 & 1,55 & 1,55 & 4,81 & 87,23 \\ \text { Hom } & 2,20 & 1,89 & 1,53 & 1,42 & 4,73 & 91,96\end{array}$


Groups $M D \& O$

Average dissimilarity $=33,68$

$\begin{array}{lrrrrrl}\text { Group MD } & \text { Group O } & & & & \\ \text { Aph } & \text { Av.Abund } & \text { Av.Abund } & \text { Av.Diss } & \text { Diss/SD } & \text { Contrib\% } & \text { Cum.\% } \\ \mathrm{Al} & 2,88 & 1,99 & 4,31 & 1,42 & 12,81 & 12,81 \\ \mathrm{Ag} & 4,14 & 2,24 & 3,96 & 1,54 & 11,77 & 24,57 \\ \mathrm{Do} & 2,78 & 0,93 & 3,45 & 1,57 & 10,23 & 34,80 \\ \mathrm{Eu} & 0,70 & 2,15 & 2,93 & 1,70 & 8,69 & 43,50 \\ \mathrm{Op} & 2,88 & 2,34 & 2,62 & 1,55 & 7,77 & 51,27 \\ \mathrm{He} & 2,28 & 1,24 & 2,61 & 1,61 & 7,75 & 59,02 \\ \mathrm{Hom} & 1,46 & 1,09 & 2,24 & 1,30 & 6,65 & 65,66 \\ \mathrm{Ro} & 1,09 & 1,89 & 1,83 & 1,30 & 5,42 & 71,08 \\ \mathrm{Ch} & 2,32 & 2,02 & 1,66 & 1,70 & 4,94 & 76,02 \\ \mathrm{Mir} & 2,03 & 2,60 & 1,58 & 1,29 & 4,70 & 80,72 \\ \mathrm{Mig} & 0,00 & 0,78 & 1,53 & 0,77 & 4,53 & 85,25 \\ \mathrm{Br} & 4,37 & 4,09 & 1,46 & 1,42 & 4,35 & 89,60 \\ & 2,34 & 2,40 & 1,42 & 1,53 & 4,21 & 93,81\end{array}$


Appendix E.

Year 2012

SIMPER - Similarity Percentages

Subfamilies contributions

\section{Parameters}

Resemblance: Bray Curtis similarity

Cut off for low contributions: $90,00 \%$

\section{Factor Groups}

Sample Time

C1 1

MD1 1

O1 1

C2 2

MD2 2

O2 2

C3 3

MD3 3

O3 3

$\mathrm{C} 4 \quad 4$

MD4 4

O4 4

C5 5

MD5 5

O5 5

C6 6

MD6 6

O6 6

C7 7

MD7 7

O7 7

C8 8

MD8 8

O8 8

C9 9

MD9 9

O9 9 


\section{Group 1}

Average similarity: 82,45

$\begin{array}{lrrrrl}\text { Species } & \text { Av.Abund } & \text { Av.Sim } & \text { Sim/SD } & \text { Contrib\% } & \text { Cum.\% } \\ \text { Aph } & 5,18 & 16,30 & 35,98 & 19,77 & 19,77 \\ \text { Al } & 3,88 & 12,11 & 22,88 & 14,69 & 34,46 \\ \text { Eu } & 3,46 & 10,25 & 8,12 & 12,43 & 46,89 \\ \text { Mig } & 3,00 & 9,49 & 9,08 & 11,50 & 58,40 \\ \text { Hom } & 2,33 & 6,98 & 24,17 & 8,47 & 66,86 \\ \text { Br } & 2,19 & 6,61 & 5,20 & 8,02 & 74,88 \\ \text { He } & 2,38 & 6,15 & 5,42 & 7,46 & 82,34 \\ \text { Ro } & 1,48 & 4,01 & 7,35 & 4,86 & 87,21 \\ \text { Op } & 1,52 & 4,00 & 9,22 & 4,85 & 92,06\end{array}$

Group 2

Average similarity: 86,55

$\begin{array}{lrrrrl}\text { Species } & \text { Av.Abund } & \text { Av.Sim } & \text { Sim/SD } & \text { Contrib\% } & \text { Cum.\% } \\ \text { Aph } & 5,59 & 13,51 & 60,67 & 15,61 & 15,61 \\ \text { Mig } & 4,42 & 11,08 & 21,05 & 12,81 & 28,42 \\ \text { Eu } & 4,31 & 10,37 & 37,77 & 11,99 & 40,40 \\ \text { Al } & 4,26 & 10,27 & 11,67 & 11,87 & 52,27 \\ \mathrm{He} & 3,62 & 9,02 & 24,18 & 10,42 & 62,69 \\ \mathrm{Br} & 3,05 & 7,71 & 70,71 & 8,91 & 71,60 \\ \text { Op } & 3,03 & 6,66 & 6,12 & 7,70 & 79,29 \\ \text { Do } & 2,13 & 4,88 & 12,29 & 5,64 & 84,93 \\ \text { Ch } & 2,38 & 4,56 & 7,69 & 5,27 & 90,20\end{array}$

Group 3

Average similarity: 82,41

$\begin{array}{lrrrrl}\text { Species } & \text { Av.Abund } & \text { Av.Sim } & \text { Sim/SD } & \text { Contrib\% } & \text { Cum.\% } \\ \text { Mig } & 5,03 & 11,47 & 39,73 & 13,92 & 13,92 \\ \text { Al } & 4,55 & 10,79 & 7,83 & 13,09 & 27,01 \\ \text { Eu } & 3,82 & 8,74 & 56,18 & 10,61 & 37,62 \\ \text { Aph } & 3,92 & 8,73 & 29,72 & 10,59 & 48,21 \\ \text { Br } & 3,46 & 8,03 & 56,60 & 9,74 & 57,95 \\ \text { Ch } & 3,63 & 7,01 & 7,65 & 8,51 & 66,46 \\ \text { Op } & 3,02 & 6,73 & 55,99 & 8,17 & 74,63 \\ \text { Ro } & 3,29 & 6,63 & 4,26 & 8,05 & 82,68 \\ \text { Ag } & 2,13 & 4,40 & 4,35 & 5,33 & 88,01 \\ \mathrm{He} & 2,16 & 3,52 & 3,10 & 4,28 & 92,29\end{array}$




\section{Group 4}

Average similarity: 79,39

$\begin{array}{lrrrrl}\text { Species } & \text { Av.Abund } & \text { Av.Sim } & \text { Sim/SD } & \text { Contrib\% } & \text { Cum.\% } \\ \text { Mig } & 4,99 & 14,35 & 11,35 & 18,07 & 18,07 \\ \text { Ch } & 3,85 & 10,54 & 4,47 & 13,28 & 31,35 \\ \text { Br } & 3,27 & 8,47 & 12,09 & 10,67 & 42,02 \\ \text { Ro } & 2,73 & 7,35 & 13,32 & 9,25 & 51,27 \\ \text { Eu } & 3,05 & 6,83 & 4,62 & 8,61 & 59,88 \\ \text { Al } & 3,34 & 6,72 & 10,76 & 8,47 & 68,34 \\ \text { Op } & 2,51 & 5,76 & 11,36 & 7,25 & 75,59 \\ \text { Aph } & 2,27 & 5,29 & 8,46 & 6,67 & 82,26 \\ \text { Hom } & 1,93 & 4,55 & 1,81 & 5,73 & 87,99 \\ \text { Ag } & 2,33 & 4,22 & 1,17 & 5,31 & 93,31\end{array}$

Group 5

Average similarity: 74,68

$\begin{array}{lrrrrl}\text { Species } & \text { Av.Abund } & \text { Av.Sim } & \text { Sim/SD } & \text { Contrib\% } & \text { Cum.\% } \\ \text { Mig } & 3,83 & 14,09 & 5,44 & 18,86 & 18,86 \\ \mathrm{Ch} & 2,65 & 9,16 & 4,33 & 12,26 & 31,13 \\ \mathrm{Ro} & 2,43 & 9,14 & 7,99 & 12,24 & 43,36 \\ \mathrm{Br} & 2,38 & 8,70 & 19,58 & 11,64 & 55,01 \\ \mathrm{Eu} & 2,19 & 7,07 & 4,01 & 9,46 & 64,47 \\ \mathrm{He} & 1,52 & 5,86 & 14,92 & 7,85 & 72,32 \\ \mathrm{Ag} & 1,84 & 4,64 & 14,92 & 6,22 & 78,54 \\ \mathrm{Al} & 1,79 & 4,64 & 14,92 & 6,22 & 84,76 \\ \mathrm{Hor} & 1,06 & 3,50 & 3,49 & 4,69 & 89,44 \\ \text { Aph } & 0,69 & 2,93 & 14,92 & 3,92 & 93,37\end{array}$

Group 6

Average similarity: 67,05

$\begin{array}{lrrrrl}\text { Species } & \text { Av.Abund } & \text { Av.Sim } & \text { Sim/SD } & \text { Contrib\% } & \text { Cum.\% } \\ \text { Mig } & 4,30 & 14,42 & 10,31 & 21,51 & 21,51 \\ \text { Ch } & 3,01 & 9,99 & 6,17 & 14,91 & 36,41 \\ \text { Hom } & 2,42 & 8,18 & 5,67 & 12,20 & 48,61 \\ \text { Ro } & 2,74 & 8,13 & 6,71 & 12,12 & 60,73 \\ \mathrm{Br} & 2,48 & 7,66 & 13,36 & 11,42 & 72,15 \\ \mathrm{Eu} & 2,04 & 5,99 & 11,16 & 8,94 & 81,09 \\ \mathrm{Al} & 2,31 & 5,16 & 11,16 & 7,70 & 88,78 \\ \mathrm{Ag} & 2,32 & 2,97 & 0,58 & 4,43 & 93,21\end{array}$


Group 7

Average similarity: 68,83

$\begin{array}{lrrrrl}\text { Species } & \text { Av.Abund } & \text { Av.Sim } & \text { Sim/SD } & \text { Contrib\% } & \text { Cum.\% } \\ \text { Mig } & 4,57 & 16,50 & 28,16 & 23,97 & 23,97 \\ \text { Hom } & 2,40 & 8,52 & 5,36 & 12,37 & 36,35 \\ \text { Br } & 2,40 & 7,25 & 5,85 & 10,54 & 46,89 \\ \text { Ro } & 2,27 & 6,94 & 9,97 & 10,08 & 56,97 \\ \text { Ch } & 2,60 & 6,80 & 4,34 & 9,89 & 66,86 \\ \text { Ag } & 2,49 & 5,85 & 2,44 & 8,50 & 75,36 \\ \text { Eu } & 1,36 & 3,89 & 1,71 & 5,65 & 81,01 \\ \text { Op } & 1,19 & 3,11 & 6,13 & 4,52 & 85,52 \\ \text { Do } & 1,16 & 2,65 & 9,45 & 3,86 & 89,38 \\ \text { Mir } & 1,07 & 2,19 & 0,58 & 3,19 & 92,57\end{array}$

Group 8

Average similarity: 67,35

$\begin{array}{lrrrrl}\text { Species } & \text { Av.Abund } & \text { Av.Sim } & \text { Sim/SD } & \text { Contrib\% } & \text { Cum.\% } \\ \text { Mig } & 3,51 & 16,15 & 23,91 & 23,97 & 23,97 \\ \text { Ch } & 2,33 & 9,50 & 13,75 & 14,10 & 38,07 \\ \text { Br } & 1,92 & 7,53 & 9,09 & 11,18 & 49,25 \\ \text { Ro } & 1,80 & 7,14 & 26,87 & 10,60 & 59,85 \\ \text { Al } & 1,75 & 6,13 & 10,07 & 9,10 & 68,95 \\ \text { Eu } & 1,13 & 4,28 & 3,26 & 6,36 & 75,31 \\ \text { Hom } & 1,06 & 4,28 & 3,26 & 6,36 & 81,67 \\ \text { Mir } & 1,60 & 4,03 & 0,58 & 5,98 & 87,65 \\ \text { Op } & 1,00 & 3,57 & 26,87 & 5,30 & 92,95\end{array}$

Group 9

Average similarity: 68,75

$\begin{array}{lrrrrl}\text { Species } & \text { Av.Abund } & \text { Av.Sim } & \text { Sim/SD } & \text { Contrib\% } & \text { Cum.\% } \\ \text { Mig } & 3,95 & 17,12 & 13,94 & 24,91 & 24,91 \\ \text { Ch } & 2,55 & 10,68 & 7,23 & 15,53 & 40,44 \\ \text { Al } & 2,82 & 8,60 & 11,40 & 12,51 & 52,95 \\ \text { Br } & 2,47 & 7,95 & 2,28 & 11,56 & 64,51 \\ \text { Ro } & 1,50 & 5,54 & 6,00 & 8,06 & 72,57 \\ \text { Ag } & 1,60 & 4,56 & 1,89 & 6,63 & 79,20 \\ \text { Op } & 1,55 & 4,09 & 2,24 & 5,95 & 85,15 \\ \text { Hom } & 1,67 & 3,23 & 0,58 & 4,70 & 89,85 \\ \text { Hor } & 0,69 & 3,06 & 15,43 & 4,45 & 94,30\end{array}$


Groups $1 \& 2$

Average dissimilarity $=20,51$

$$
\text { Group } 1 \text { Group } 2
$$

$\begin{array}{lrrrrrl}\text { Species } & \text { Av.Abund } & \text { Av.Abund } & \text { Av.Diss } & \text { Diss/SD } & \text { Contrib\% } & \text { Cum.\% } \\ \text { Op } & 1,52 & 3,03 & 2,24 & 1,90 & 10,94 & 10,94 \\ \text { Mig } & 3,00 & 4,42 & 2,07 & 4,13 & 10,09 & 21,04 \\ \text { Do } & 0,83 & 2,13 & 1,93 & 1,74 & 9,39 & 30,43 \\ \text { Hom } & 2,33 & 1,06 & 1,89 & 2,60 & 9,20 & 39,63 \\ \text { He } & 2,38 & 3,62 & 1,83 & 1,62 & 8,91 & 48,54 \\ \text { Ch } & 1,30 & 2,38 & 1,55 & 1,08 & 7,55 & 56,09 \\ \text { Ag } & 0,46 & 1,13 & 1,47 & 1,21 & 7,17 & 63,27 \\ \text { Eu } & 3,46 & 4,31 & 1,33 & 1,30 & 6,47 & 69,74 \\ \text { Br } & 2,19 & 3,05 & 1,25 & 2,64 & 6,08 & 75,82 \\ \text { Aph } & 5,18 & 5,59 & 0,99 & 1,29 & 4,81 & 80,63 \\ \text { Ro } & 1,48 & 1,46 & 0,85 & 1,61 & 4,16 & 84,79 \\ \text { Al } & 3,88 & 4,26 & 0,84 & 1,32 & 4,09 & 88,87 \\ \text { Mac } & 0,60 & 0,37 & 0,84 & 1,15 & 4,07 & 92,95\end{array}$

Groups 1 \& 3

Average dissimilarity $=26,14$

$\begin{array}{lrrrrrl}\text { Species } & \text { Group 1 } & \text { Group 3 } & & & & \\ \text { Ch } & \text { Avund } & \text { Av.Abund } & \text { Av.Diss } & \text { Diss/SD } & \text { Contrib\% } & \text { Cum.\% } \\ \text { Mig } & 1,30 & 3,63 & 3,19 & 2,57 & 12,19 & 12,19 \\ \mathrm{Ag} & 3,00 & 5,03 & 2,83 & 5,16 & 10,82 & 23,01 \\ \mathrm{Ro} & 0,46 & 2,13 & 2,48 & 1,73 & 9,49 & 32,51 \\ \text { Op } & 1,48 & 3,29 & 2,48 & 2,24 & 9,49 & 42,00 \\ \mathrm{Aph} & 1,52 & 3,02 & 2,11 & 2,80 & 8,09 & 50,09 \\ \mathrm{Br} & 5,18 & 3,92 & 1,84 & 1,76 & 7,03 & 57,11 \\ \text { Hor } & 2,19 & 3,46 & 1,77 & 3,79 & 6,79 & 63,90 \\ \text { Do } & 0,73 & 1,68 & 1,56 & 1,64 & 5,98 & 69,88 \\ \text { Hom } & 0,83 & 1,29 & 1,53 & 1,23 & 5,85 & 75,72 \\ \text { He } & 2,33 & 1,73 & 1,34 & 1,18 & 5,13 & 80,85 \\ \text { Al } & 2,38 & 2,16 & 1,32 & 1,23 & 5,05 & 85,90 \\ \text { Mac } & 3,88 & 4,55 & 1,02 & 1,66 & 3,89 & 89,79 \\ & 0,60 & 0,37 & 0,81 & 1,14 & 3,10 & 92,89\end{array}$


Groups 2 \& 3

Average dissimilarity $=18,49$

$$
\text { Group } 2 \text { Group } 3
$$

$\begin{array}{lrrrrrl}\text { Species } & \text { Av.Abund } & \text { Av.Abund } & \text { Av.Diss } & \text { Diss/SD } & \text { Contrib\% } & \text { Cum.\% } \\ \text { Ro } & 1,46 & 3,29 & 2,26 & 1,91 & 12,23 & 12,23 \\ \text { Aph } & 5,59 & 3,92 & 2,16 & 1,92 & 11,71 & 23,94 \\ \text { He } & 3,62 & 2,16 & 1,96 & 1,40 & 10,57 & 34,51 \\ \text { Ch } & 2,38 & 3,63 & 1,86 & 1,58 & 10,06 & 44,58 \\ \text { Do } & 2,13 & 1,29 & 1,69 & 1,46 & 9,16 & 53,74 \\ \text { Ag } & 1,13 & 2,13 & 1,36 & 1,10 & 7,35 & 61,10 \\ \text { Hom } & 1,06 & 1,73 & 1,13 & 1,51 & 6,09 & 67,18 \\ \text { Hor } & 1,06 & 1,68 & 1,07 & 1,53 & 5,79 & 72,97 \\ \text { Mig } & 4,42 & 5,03 & 0,93 & 1,84 & 5,01 & 77,99 \\ \text { Op } & 3,03 & 3,02 & 0,79 & 1,59 & 4,30 & 82,28 \\ \text { Eu } & 4,31 & 3,82 & 0,78 & 1,04 & 4,24 & 86,52 \\ \text { Met } & 0,00 & 0,60 & 0,72 & 1,25 & 3,87 & 90,39\end{array}$

Groups $1 \& 4$

Average dissimilarity $=31,27$

Group $1 \quad$ Group 4

$\begin{array}{lrrrrrr}\text { Species } & \text { Av.Abund } & \text { Av.Abund } & \text { Av.Diss } & \text { Diss/SD } & \text { Contrib\% } & \text { Cum.\% } \\ \text { Aph } & 5,18 & 2,27 & 4,65 & 3,31 & 14,87 & 14,87 \\ \text { Ch } & 1,30 & 3,85 & 4,03 & 3,63 & 12,90 & 27,77 \\ \text { Mig } & 3,00 & 4,99 & 3,12 & 8,07 & 9,97 & 37,74 \\ \mathrm{Ag} & 0,46 & 2,33 & 3,11 & 1,81 & 9,96 & 47,70 \\ \mathrm{Al} & 3,88 & 3,34 & 2,29 & 2,78 & 7,31 & 55,01 \\ \mathrm{He} & 2,38 & 1,19 & 2,16 & 1,21 & 6,90 & 61,91 \\ \mathrm{Ro} & 1,48 & 2,73 & 1,93 & 2,79 & 6,18 & 68,09 \\ \mathrm{Do} & 0,83 & 1,36 & 1,76 & 1,35 & 5,64 & 73,74 \\ \mathrm{Br} & 2,19 & 3,27 & 1,63 & 2,00 & 5,22 & 78,96 \\ \mathrm{Op} & 1,52 & 2,51 & 1,59 & 1,28 & 5,09 & 84,05 \\ \mathrm{Eu} & 3,46 & 3,05 & 1,44 & 1,28 & 4,60 & 88,65 \\ \mathrm{Hom} & 2,33 & 1,93 & 0,96 & 1,38 & 3,09 & 91,73\end{array}$

Groups $2 \& 4$

Average dissimilarity $=25,17$

Group 2 Group 4

$\begin{array}{lrrrrrr}\text { Species } & \text { Av.Abund } & \text { Av.Abund } & \text { Av.Diss } & \text { Diss/SD } & \text { Contrib\% } & \text { Cum.\% } \\ \text { Aph } & 5,59 & 2,27 & 4,69 & 3,33 & 18,63 & 18,63 \\ \mathrm{He} & 3,62 & 1,19 & 3,46 & 2,13 & 13,76 & 32,38 \\ \mathrm{Ag} & 1,13 & 2,33 & 2,25 & 2,04 & 8,93 & 41,32 \\ \mathrm{Al} & 4,26 & 3,34 & 2,23 & 2,03 & 8,85 & 50,17\end{array}$




$\begin{array}{lllllll}\text { Ch } & 2,38 & 3,85 & 2,20 & 1,65 & 8,74 & 58,91 \\ \text { Eu } & 4,31 & 3,05 & 1,91 & 1,27 & 7,57 & 66,48 \\ \text { Ro } & 1,46 & 2,73 & 1,75 & 1,92 & 6,95 & 73,44 \\ \text { Do } & 2,13 & 1,36 & 1,44 & 1,17 & 5,74 & 79,18 \\ \text { Op } & 3,03 & 2,51 & 1,37 & 1,52 & 5,44 & 84,62 \\ \text { Hom } & 1,06 & 1,93 & 1,35 & 1,53 & 5,37 & 89,98 \\ \text { Mig } & 4,42 & 4,99 & 0,81 & 1,49 & 3,22 & 93,20\end{array}$

Groups $3 \& 4$

Average dissimilarity $=19,53$

$$
\text { Group } 3 \text { Group } 4
$$

Species Av.Abund Av.Abund

Al

$$
4,55
$$

3,34

Av.Diss

Diss/SD

$$
\text { Contrib\% Cum.\% }
$$

2,32

1,78

$11,90 \quad 11,90$

Aph

3,92

2,27

2,26

2,04

$11,55 \quad 23,45$

Do

1,29

1,36

1,73

1,23

$8,87 \quad 32,31$

$\mathrm{He}$

2,16

1,72

1,31

$8,83 \quad 41,14$

Ag

2,13

2,33

1,58

1,90

$8,07 \quad 49,22$

$\mathrm{Eu}$

3,82

3,05

1,33

1,21

$6,83 \quad 56,05$

$\mathrm{Ch}$

3,63

3,85

1,26

1,45

$6,48 \quad 62,52$

Op

3,02

2,51

1,25

2,25

$6,39 \quad 68,91$

Hom

1,73

1,93

1,22

1,33

$6,26 \quad 75,17$

Ro

3,29

2,73

1,21

2,07

$6,21 \quad 81,38$

Hor

1,68

1,13

1,10

1,52

$5,63 \quad 87,01$

Met

0,60

0,00

0,75

1,25

$3,85 \quad 90,86$

Groups $1 \& 5$

Average dissimilarity $=34,74$

$$
\text { Group } 1 \quad \text { Group } 5
$$

$\begin{array}{lrrrrrr}\text { Species } & \text { Av.Abund } & \text { Av.Abund } & \text { Av.Diss } & \text { Diss/SD } & \text { Contrib\% } & \text { Cum.\% } \\ \text { Aph } & 5,18 & 0,69 & 8,39 & 13,26 & 24,15 & 24,15 \\ \text { Al } & 3,88 & 1,79 & 3,98 & 1,86 & 11,45 & 35,60 \\ \text { Ag } & 0,46 & 1,84 & 2,78 & 1,37 & 8,02 & 43,61 \\ \text { Hom } & 2,33 & 0,92 & 2,59 & 1,90 & 7,46 & 51,07 \\ \text { Ch } & 1,30 & 2,65 & 2,51 & 1,75 & 7,23 & 58,30 \\ \text { Eu } & 3,46 & 2,19 & 2,44 & 1,51 & 7,03 & 65,33 \\ \text { Op } & 1,52 & 1,41 & 1,98 & 1,53 & 5,70 & 71,02 \\ \text { Ro } & 1,48 & 2,43 & 1,75 & 1,89 & 5,03 & 76,05 \\ \text { He } & 2,38 & 1,52 & 1,67 & 1,31 & 4,81 & 80,86 \\ \text { Mig } & 3,00 & 3,83 & 1,66 & 1,57 & 4,78 & 85,64 \\ \text { Do } & 0,83 & 0,77 & 1,38 & 1,37 & 3,96 & 89,60 \\ \text { Hor } & 0,73 & 1,06 & 0,98 & 1,04 & 2,83 & 92,43\end{array}$


Groups $2 \& 5$

Average dissimilarity $=33,34$

$$
\text { Group } 2 \text { Group } 5
$$

$\begin{array}{lrrrrrl}\text { Species } & \text { Av.Abund } & \text { Av.Abund } & \text { Av.Diss } & \text { Diss/SD } & \text { Contrib\% } & \text { Cum.\% } \\ \text { Aph } & 5,59 & 0,69 & 7,96 & 8,57 & 23,87 & 23,87 \\ \mathrm{Al} & 4,26 & 1,79 & 4,05 & 2,10 & 12,14 & 36,01 \\ \mathrm{Eu} & 4,31 & 2,19 & 3,47 & 2,33 & 10,41 & 46,42 \\ \mathrm{He} & 3,62 & 1,52 & 3,40 & 6,89 & 10,19 & 56,61 \\ \mathrm{Op} & 3,03 & 1,41 & 2,90 & 1,37 & 8,69 & 65,30 \\ \mathrm{Do} & 2,13 & 0,77 & 2,16 & 1,78 & 6,49 & 71,78 \\ \mathrm{Ag} & 1,13 & 1,84 & 1,97 & 1,51 & 5,91 & 77,69 \\ \mathrm{Ro} & 1,46 & 2,43 & 1,61 & 1,55 & 4,83 & 82,52 \\ \mathrm{CH} & 2,38 & 2,65 & 1,45 & 1,37 & 4,35 & 86,87 \\ \mathrm{Mig} & 4,42 & 3,83 & 1,14 & 1,17 & 3,41 & 90,28\end{array}$

Groups 3 \& 5

Average dissimilarity $=30,96$

$$
\text { Group } 3 \text { Group } 5
$$

$\begin{array}{lrrrrrl}\text { Species } & \text { Av.Abund } & \text { Av.Abund } & \text { Av.Diss } & \text { Diss/SD } & \text { Contrib\% } & \text { Cum.\% } \\ \text { Aph } & 3,92 & 0,69 & 5,03 & 8,80 & 16,23 & 16,23 \\ \text { Al } & 4,55 & 1,79 & 4,41 & 2,31 & 14,24 & 30,47 \\ \text { Op } & 3,02 & 1,41 & 2,66 & 1,38 & 8,58 & 39,05 \\ \text { Eu } & 3,82 & 2,19 & 2,54 & 2,14 & 8,21 & 47,26 \\ \text { Mig } & 5,03 & 3,83 & 1,87 & 1,65 & 6,04 & 53,30 \\ \text { Ch } & 3,63 & 2,65 & 1,79 & 1,46 & 5,78 & 59,08 \\ \text { Do } & 1,29 & 0,77 & 1,77 & 1,35 & 5,73 & 64,81 \\ \text { Ag } & 2,13 & 1,84 & 1,74 & 1,97 & 5,62 & 70,43 \\ \text { Hom } & 1,73 & 0,92 & 1,67 & 1,71 & 5,41 & 75,84 \\ \text { Br } & 3,46 & 2,38 & 1,67 & 2,21 & 5,40 & 81,23 \\ \text { Ro } & 3,29 & 2,43 & 1,61 & 1,91 & 5,21 & 86,44 \\ \text { He } & 2,16 & 1,52 & 1,38 & 1,69 & 4,44 & 90,88\end{array}$

Groups 4 \& 5

Average dissimilarity $=25,85$

$$
\text { Group } 4 \text { Group } 5
$$

$\begin{array}{lrrrrrr}\text { Species } & \text { Av.Abund } & \text { Av.Abund } & \text { Av.Diss } & \text { Diss/SD } & \text { Contrib\% } & \text { Cum.\% } \\ \text { Al } & 3,34 & 1,79 & 3,20 & 1,54 & 12,36 & 12,36 \\ \text { Aph } & 2,27 & 0,69 & 2,67 & 3,29 & 10,33 & 22,70 \\ \text { Op } & 2,51 & 1,41 & 2,61 & 1,49 & 10,08 & 32,78 \\ \text { Ag } & 2,33 & 1,84 & 2,33 & 1,33 & 9,00 & 41,78 \\ \text { Ch } & 3,85 & 2,65 & 2,19 & 1,70 & 8,47 & 50,25 \\ \text { Mig } & 4,99 & 3,83 & 2,03 & 1,69 & 7,84 & 58,09\end{array}$




$\begin{array}{lllllll}\text { Hom } & 1,93 & 0,92 & 2,00 & 1,53 & 7,73 & 65,82 \\ \mathrm{Do} & 1,36 & 0,77 & 1,97 & 1,30 & 7,64 & 73,46 \\ \mathrm{Eu} & 3,05 & 2,19 & 1,96 & 1,51 & 7,58 & 81,04 \\ \mathrm{Br} & 3,27 & 2,38 & 1,61 & 1,78 & 6,23 & 87,27 \\ \mathrm{He} & 1,19 & 1,52 & 1,41 & 1,13 & 5,46 & 92,73\end{array}$

Groups $1 \& 6$

Average dissimilarity $=37,55$

Group $1 \quad$ Group 6

$\begin{array}{lrrrrrl}\text { Species } & \text { Av.Abund } & \text { Av.Abund } & \text { Av.Diss } & \text { Diss/SD } & \text { Contrib\% } & \text { Cum.\% } \\ \text { Aph } & 5,18 & 0,73 & 7,97 & 3,29 & 21,21 & 21,21 \\ \text { Ag } & 0,46 & 2,32 & 3,68 & 1,35 & 9,80 & 31,01 \\ \text { Al } & 3,88 & 2,31 & 3,29 & 1,63 & 8,76 & 39,77 \\ \text { Ch } & 1,30 & 3,01 & 3,03 & 2,65 & 8,06 & 47,83 \\ \text { He } & 2,38 & 0,69 & 2,91 & 1,93 & 7,74 & 55,57 \\ \text { Eu } & 3,46 & 2,04 & 2,59 & 1,75 & 6,91 & 62,48 \\ \text { Mig } & 3,00 & 4,30 & 2,23 & 2,51 & 5,94 & 68,42 \\ \text { Ro } & 1,48 & 2,74 & 2,14 & 1,72 & 5,71 & 74,14 \\ \text { Mir } & 0,23 & 1,17 & 2,00 & 1,16 & 5,33 & 79,46 \\ \text { Do } & 0,83 & 0,83 & 1,98 & 1,40 & 5,28 & 84,74 \\ \text { Op } & 1,52 & 0,83 & 1,36 & 1,06 & 3,62 & 88,36 \\ \text { Hor } & 0,73 & 0,69 & 1,11 & 1,36 & 2,95 & 91,32\end{array}$

Groups $2 \& 6$

Average dissimilarity $=38,97$

Group 2 Group 6

$\begin{array}{lrrrrrl}\text { Species } & \text { Av.Abund } & \text { Av.Abund } & \text { Av.Diss } & \text { Diss/SD } & \text { Contrib\% } & \text { Cum.\% } \\ \text { Aph } & 5,59 & 0,73 & 7,59 & 3,40 & 19,49 & 19,49 \\ \mathrm{He} & 3,62 & 0,69 & 4,47 & 6,18 & 11,46 & 30,95 \\ \mathrm{Eu} & 4,31 & 2,04 & 3,56 & 2,53 & 9,12 & 40,07 \\ \mathrm{Op} & 3,03 & 0,83 & 3,43 & 2,28 & 8,81 & 48,88 \\ \mathrm{Al} & 4,26 & 2,31 & 3,29 & 1,62 & 8,44 & 57,32 \\ \mathrm{Ag} & 1,13 & 2,32 & 2,91 & 1,61 & 7,48 & 64,80 \\ \text { Do } & 2,13 & 0,83 & 2,38 & 1,79 & 6,12 & 70,92 \\ \text { Hom } & 1,06 & 2,42 & 2,12 & 2,93 & 5,45 & 76,36 \\ \text { Ro } & 1,46 & 2,74 & 1,97 & 1,57 & 5,05 & 81,42 \\ \text { Mir } & 0,00 & 1,17 & 1,89 & 1,11 & 4,84 & 86,26 \\ \text { Ch } & 2,38 & 3,01 & 1,59 & 1,69 & 4,07 & 90,33\end{array}$


Groups 3 \& 6

Average dissimilarity $=32,97$

$$
\text { Group } 3 \text { Group } 6
$$

$\begin{array}{lrrrrrl}\text { Species } & \text { Av.Abund } & \text { Av.Abund } & \text { Av.Diss } & \text { Diss/SD } & \text { Contrib\% } & \text { Cum.\% } \\ \text { Aph } & 3,92 & 0,73 & 4,81 & 2,49 & 14,60 & 14,60 \\ \text { Al } & 4,55 & 2,31 & 3,48 & 1,53 & 10,56 & 25,15 \\ \text { Op } & 3,02 & 0,83 & 3,25 & 2,91 & 9,87 & 35,03 \\ \text { Eu } & 3,82 & 2,04 & 2,67 & 2,42 & 8,09 & 43,12 \\ \text { Ag } & 2,13 & 2,32 & 2,42 & 1,64 & 7,34 & 50,46 \\ \text { He } & 2,16 & 0,69 & 2,14 & 1,77 & 6,49 & 56,94 \\ \text { Do } & 1,29 & 0,83 & 1,94 & 1,12 & 5,89 & 62,84 \\ \text { Mir } & 0,00 & 1,17 & 1,82 & 1,09 & 5,53 & 68,37 \\ \text { Hor } & 1,68 & 0,69 & 1,64 & 1,46 & 4,98 & 73,35 \\ \text { Br } & 3,46 & 2,48 & 1,47 & 1,75 & 4,47 & 77,82 \\ \text { Hom } & 1,73 & 2,42 & 1,44 & 1,13 & 4,38 & 82,20 \\ \text { Ro } & 3,29 & 2,74 & 1,44 & 1,48 & 4,36 & 86,56 \\ \text { Ch } & 3,63 & 3,01 & 1,38 & 1,44 & 4,20 & 90,76\end{array}$

Groups 4 \& 6

Average dissimilarity $=27,15$

$\begin{array}{lrrrrrl}\text { Group 4 } & \text { Group 6 } & & & & \\ \text { Species } & \text { Av.Abund } & \text { Av.Abund } & \text { Av.Diss } & \text { Diss/SD } & \text { Contrib\% } & \text { Cum.\% } \\ \mathrm{Ag} & 2,33 & 2,32 & 2,99 & 1,44 & 11,00 & 11,00 \\ \mathrm{Al} & 3,34 & 2,31 & 2,91 & 1,58 & 10,71 & 21,72 \\ \mathrm{Aph} & 2,27 & 0,73 & 2,79 & 1,64 & 10,26 & 31,98 \\ \mathrm{Op} & 2,51 & 0,83 & 2,73 & 1,66 & 10,05 & 42,03 \\ \text { Do } & 1,36 & 0,83 & 2,13 & 1,11 & 7,85 & 49,88 \\ \text { Mir } & 0,00 & 1,17 & 2,02 & 1,10 & 7,46 & 57,33 \\ \text { Eu } & 3,05 & 2,04 & 1,98 & 1,48 & 7,28 & 64,61 \\ \mathrm{He} & 1,19 & 0,69 & 1,54 & 1,42 & 5,68 & 70,29 \\ \mathrm{Ch} & 3,85 & 3,01 & 1,51 & 1,75 & 5,57 & 75,86 \\ \mathrm{Br} & 3,27 & 2,48 & 1,48 & 1,68 & 5,45 & 81,31 \\ \text { Mig } & 4,99 & 4,30 & 1,23 & 1,40 & 4,55 & 85,85 \\ \text { Hor } & 1,13 & 0,69 & 1,11 & 1,27 & 4,09 & 89,95 \\ \text { Ro } & 2,73 & 2,74 & 1,04 & 1,70 & 3,83 & 93,78\end{array}$


Groups $5 \& 6$

Average dissimilarity $=28,09$

$$
\text { Group } 5 \text { Group } 6
$$

$\begin{array}{lrrrrrr}\text { Species } & \text { Av.Abund } & \text { Av.Abund } & \text { Av.Diss } & \text { Diss/SD } & \text { Contrib\% } & \text { Cum.\% } \\ \text { Ag } & 1,84 & 2,32 & 3,66 & 1,82 & 13,04 & 13,04 \\ \text { Hom } & 0,92 & 2,42 & 2,94 & 2,08 & 10,46 & 23,49 \\ \text { Al } & 1,79 & 2,31 & 2,48 & 1,17 & 8,82 & 32,32 \\ \text { Mir } & 0,00 & 1,17 & 2,45 & 1,10 & 8,72 & 41,04 \\ \text { Do } & 0,77 & 0,83 & 2,22 & 1,29 & 7,89 & 48,92 \\ \text { Op } & 1,41 & 0,83 & 2,21 & 1,22 & 7,87 & 56,79 \\ \text { Aph } & 0,69 & 0,73 & 1,86 & 2,94 & 6,63 & 63,42 \\ \text { He } & 1,52 & 0,69 & 1,57 & 1,38 & 5,58 & 69,00 \\ \text { Mig } & 3,83 & 4,30 & 1,49 & 1,44 & 5,29 & 74,29 \\ \text { Eu } & 2,19 & 2,04 & 1,42 & 1,40 & 5,05 & 79,34 \\ \text { Ch } & 2,65 & 3,01 & 1,34 & 1,36 & 4,76 & 84,10 \\ \text { Ro } & 2,43 & 2,74 & 1,21 & 1,21 & 4,31 & 88,41 \\ \text { Hor } & 1,06 & 0,69 & 1,18 & 1,19 & 4,21 & 92,62\end{array}$

Groups $1 \& 7$

Average dissimilarity $=37,48$

$\begin{array}{lrrrrrl} & \text { Group 1 } & \text { Group 7 } & & & & \\ \text { Species } & \text { Av.Abund } & \text { Av.Abund } & \text { Av.Diss } & \text { Diss/SD } & \text { Contrib\% } & \text { Cum.\% } \\ \text { Aph } & 5,18 & 0,77 & 8,01 & 3,91 & 21,36 & 21,36 \\ \mathrm{Al} & 3,88 & 1,92 & 3,99 & 1,25 & 10,66 & 32,01 \\ \mathrm{Eu} & 3,46 & 1,36 & 3,73 & 3,12 & 9,95 & 41,96 \\ \mathrm{Ag} & 0,46 & 2,49 & 3,64 & 1,77 & 9,72 & 51,68 \\ \mathrm{He} & 2,38 & 0,83 & 2,94 & 1,49 & 7,83 & 59,51 \\ \mathrm{Mig} & 3,00 & 4,57 & 2,74 & 5,75 & 7,32 & 66,83 \\ \mathrm{Ch} & 1,30 & 2,60 & 2,25 & 1,10 & 6,00 & 72,84 \\ \text { Mir } & 0,23 & 1,07 & 1,83 & 1,48 & 4,89 & 77,72 \\ \text { Do } & 0,83 & 1,16 & 1,52 & 1,38 & 4,05 & 81,77 \\ \mathrm{Ro} & 1,48 & 2,27 & 1,49 & 1,70 & 3,97 & 85,74 \\ \mathrm{Br} & 2,19 & 2,40 & 1,07 & 1,42 & 2,86 & 88,60 \\ \text { Op } & 1,52 & 1,19 & 1,04 & 1,32 & 2,78 & 91,38\end{array}$


Groups 2 \& 7

Average dissimilarity $=38,36$

$$
\text { Group } 2 \text { Group } 7
$$

$\begin{array}{lrrrrrl}\text { Species } & \text { Av.Abund } & \text { Av.Abund } & \text { Av.Diss } & \text { Diss/SD } & \text { Contrib\% } & \text { Cum.\% } \\ \text { Aph } & 5,59 & 0,77 & 7,62 & 4,02 & 19,86 & 19,86 \\ \mathrm{Eu} & 4,31 & 1,36 & 4,59 & 4,24 & 11,95 & 31,82 \\ \mathrm{He} & 3,62 & 0,83 & 4,43 & 2,80 & 11,55 & 43,37 \\ \mathrm{Al} & 4,26 & 1,92 & 3,94 & 1,35 & 10,28 & 53,65 \\ \mathrm{Op} & 3,03 & 1,19 & 2,92 & 2,09 & 7,61 & 61,26 \\ \mathrm{Ag} & 1,13 & 2,49 & 2,45 & 1,62 & 6,38 & 67,64 \\ \mathrm{Hom} & 1,06 & 2,40 & 2,12 & 3,18 & 5,52 & 73,16 \\ \mathrm{Mir} & 0,00 & 1,07 & 1,74 & 1,32 & 4,53 & 77,69 \\ \mathrm{Ch} & 2,38 & 2,60 & 1,63 & 1,13 & 4,26 & 81,95 \\ \mathrm{Do} & 2,13 & 1,16 & 1,60 & 1,74 & 4,17 & 86,12 \\ \mathrm{Ro} & 1,46 & 2,27 & 1,38 & 1,37 & 3,60 & 89,72 \\ \mathrm{Br} & 3,05 & 2,40 & 1,32 & 1,86 & 3,44 & 93,16\end{array}$

Groups 3 \& 7

Average dissimilarity $=34,33$

$$
\text { Group } 3 \text { Group } 7
$$

$\begin{array}{lrrrrrr}\text { Species } & \text { Av.Abund } & \text { Av.Abund } & \text { Av.Diss } & \text { Diss/SD } & \text { Contrib\% } & \text { Cum.\% } \\ \text { Aph } & 3,92 & 0,77 & 4,80 & 3,14 & 13,99 & 13,99 \\ \text { Al } & 4,55 & 1,92 & 4,17 & 1,36 & 12,15 & 26,13 \\ \text { Eu } & 3,82 & 1,36 & 3,65 & 5,10 & 10,64 & 36,77 \\ \text { Op } & 3,02 & 1,19 & 2,76 & 2,84 & 8,03 & 44,81 \\ \text { He } & 2,16 & 0,83 & 2,21 & 1,57 & 6,43 & 51,24 \\ \text { Ch } & 3,63 & 2,60 & 2,18 & 1,63 & 6,36 & 57,60 \\ \text { Ro } & 3,29 & 2,27 & 1,77 & 1,62 & 5,17 & 62,76 \\ \text { Do } & 1,29 & 1,16 & 1,74 & 1,42 & 5,06 & 67,82 \\ \text { Hor } & 1,68 & 0,60 & 1,72 & 1,45 & 5,02 & 72,85 \\ \text { Br } & 3,46 & 2,40 & 1,68 & 1,74 & 4,90 & 77,74 \\ \text { Mir } & 0,00 & 1,07 & 1,68 & 1,30 & 4,88 & 82,63 \\ \text { Ag } & 2,13 & 2,49 & 1,62 & 1,61 & 4,73 & 87,36 \\ \text { Hom } & 1,73 & 2,40 & 1,43 & 1,13 & 4,17 & 91,53\end{array}$

Groups 4 \& 7

Average dissimilarity $=27,72$

$\begin{array}{lrrrrrl} & \text { Group 4 } & \text { Group 7 } & & & & \\ \text { Species } & \text { Av.Abund } & \text { Av.Abund } & \text { Av.Diss } & \text { Diss/SD } & \text { Contrib\% } & \text { Cum.\% } \\ \text { Al } & 3,34 & 1,92 & 3,57 & 1,41 & 12,88 & 12,88 \\ \text { Eu } & 3,05 & 1,36 & 2,70 & 1,75 & 9,73 & 22,61 \\ \text { Aph } & 2,27 & 0,77 & 2,53 & 1,58 & 9,11 & 31,72\end{array}$




$\begin{array}{lllllll}\text { Ch } & 3,85 & 2,60 & 2,47 & 1,42 & 8,91 & 40,63 \\ \mathrm{Ag} & 2,33 & 2,49 & 2,28 & 1,33 & 8,21 & 48,85 \\ \mathrm{Op} & 2,51 & 1,19 & 2,17 & 1,41 & 7,83 & 56,68 \\ \text { Mir } & 0,00 & 1,07 & 1,86 & 1,30 & 6,72 & 63,40 \\ \mathrm{Do} & 1,36 & 1,16 & 1,84 & 1,56 & 6,63 & 70,04 \\ \mathrm{Br} & 3,27 & 2,40 & 1,69 & 1,67 & 6,11 & 76,15 \\ \mathrm{He} & 1,19 & 0,83 & 1,67 & 1,32 & 6,04 & 82,18 \\ \text { Hor } & 1,13 & 0,60 & 1,11 & 1,10 & 4,02 & 86,20 \\ \text { Ro } & 2,73 & 2,27 & 1,03 & 1,13 & 3,72 & 89,92 \\ \text { Hom } & 1,93 & 2,40 & 0,93 & 1,10 & 3,34 & 93,27\end{array}$

Groups $5 \& 7$

Average dissimilarity $=28,28$

$$
\text { Group } 5 \text { Group } 7
$$

$\begin{array}{lrrrrrl}\text { Species } & \text { Av.Abund } & \text { Av.Abund } & \text { Av.Diss } & \text { Diss/SD } & \text { Contrib\% } & \text { Cum.\% } \\ \text { Al } & 1,79 & 1,92 & 3,30 & 1,57 & 11,67 & 11,67 \\ \text { Hom } & 0,92 & 2,40 & 2,95 & 2,13 & 10,42 & 22,08 \\ \text { Ag } & 1,84 & 2,49 & 2,57 & 1,20 & 9,07 & 31,16 \\ \text { Mir } & 0,00 & 1,07 & 2,26 & 1,31 & 7,98 & 39,14 \\ \text { Op } & 1,41 & 1,19 & 2,21 & 1,67 & 7,82 & 46,96 \\ \text { Ch } & 2,65 & 2,60 & 2,08 & 1,58 & 7,35 & 54,31 \\ \text { Eu } & 2,19 & 1,36 & 1,88 & 1,66 & 6,65 & 60,96 \\ \text { He } & 1,52 & 0,83 & 1,86 & 1,33 & 6,58 & 67,55 \\ \text { Do } & 0,77 & 1,16 & 1,66 & 1,16 & 5,88 & 73,42 \\ \text { Mig } & 3,83 & 4,57 & 1,61 & 1,32 & 5,68 & 79,10 \\ \text { Br } & 2,38 & 2,40 & 1,26 & 1,42 & 4,47 & 83,57 \\ \text { Hor } & 1,06 & 0,60 & 1,21 & 1,06 & 4,27 & 87,84 \\ \text { Ro } & 2,43 & 2,27 & 1,15 & 1,39 & 4,05 & 91,89\end{array}$

Groups 6 \& 7

Average dissimilarity $=25,68$

$\begin{array}{lrrrrrl} & \text { Group 6 } & \text { Group 7 } & & & & \\ \text { Species } & \text { Av.Abund } & \text { Av.Abund } & \text { Av.Diss } & \text { Diss/SD } & \text { Contrib\% } & \text { Cum.\% } \\ \text { Ag } & 2,32 & 2,49 & 3,36 & 1,42 & 13,10 & 13,10 \\ \text { Al } & 2,31 & 1,92 & 3,27 & 1,32 & 12,74 & 25,83 \\ \text { Do } & 0,83 & 1,16 & 2,34 & 1,59 & 9,13 & 34,97 \\ \text { Ch } & 3,01 & 2,60 & 2,16 & 2,31 & 8,42 & 43,39 \\ \text { Mir } & 1,17 & 1,07 & 1,95 & 1,48 & 7,61 & 51,00 \\ \text { Aph } & 0,73 & 0,77 & 1,79 & 1,24 & 6,98 & 57,98 \\ \text { Ro } & 2,74 & 2,27 & 1,51 & 1,37 & 5,89 & 63,87 \\ \text { He } & 0,69 & 0,83 & 1,43 & 1,25 & 5,57 & 69,43 \\ \text { Eu } & 2,04 & 1,36 & 1,32 & 1,07 & 5,14 & 74,58\end{array}$




$\begin{array}{lllllll}\text { Op } & 0,83 & 1,19 & 1,31 & 1,31 & 5,08 & 79,66 \\ \mathrm{Br} & 2,48 & 2,40 & 1,26 & 1,21 & 4,92 & 84,58 \\ \text { Hor } & 0,69 & 0,60 & 1,10 & 1,22 & 4,28 & 88,86 \\ \text { Mig } & 4,30 & 4,57 & 1,03 & 1,48 & 4,00 & 92,87\end{array}$

Groups $1 \& 8$

Average dissimilarity $=44,38$

$\begin{array}{lrrrrrl} & \text { Group 1 } & \text { Group } 8 & & & & \\ \text { Species } & \text { Av.Abund } & \text { Av.Abund } & \text { Av.Diss } & \text { Diss/SD } & \text { Contrib\% } & \text { Cum.\% } \\ \text { Aph } & 5,18 & 0,00 & 10,51 & 21,19 & 23,69 & 23,69 \\ \text { Eu } & 3,46 & 1,13 & 4,70 & 3,94 & 10,59 & 34,27 \\ \mathrm{He} & 2,38 & 0,23 & 4,36 & 2,71 & 9,82 & 44,10 \\ \mathrm{Al} & 3,88 & 1,75 & 4,33 & 2,47 & 9,76 & 53,86 \\ \mathrm{Mir} & 0,23 & 1,60 & 3,10 & 1,50 & 6,98 & 60,84 \\ \text { Hom } & 2,33 & 1,06 & 2,58 & 2,66 & 5,81 & 66,65 \\ \text { Do } & 0,83 & 0,90 & 2,42 & 1,39 & 5,45 & 72,10 \\ \text { Ag } & 0,46 & 1,29 & 2,30 & 1,29 & 5,19 & 77,29 \\ \text { Ch } & 1,30 & 2,33 & 2,04 & 1,27 & 4,60 & 81,90 \\ \text { Op } & 1,52 & 1,00 & 1,38 & 1,71 & 3,10 & 85,00 \\ \text { Hor } & 0,73 & 0,90 & 1,35 & 1,09 & 3,05 & 88,05 \\ \text { Br } & 2,19 & 1,92 & 1,34 & 1,98 & 3,02 & 91,07\end{array}$

Groups $2 \& 8$

Average dissimilarity $=44,83$

$\begin{array}{lrrrrrl}\text { Species } & \text { Group 2 } & \text { Group } 8 & & & & \\ \text { Aph } & \text { Av.Abund } & \text { Av.Abund } & \text { Av.Diss } & \text { Diss/SD } & \text { Contrib\% } & \text { Cum.\% } \\ \mathrm{He} & 5,59 & 0,00 & 9,75 & 10,61 & 21,76 & 21,76 \\ \mathrm{Eu} & 3,62 & 0,23 & 5,91 & 8,09 & 13,18 & 34,94 \\ \mathrm{Al} & 4,31 & 1,13 & 5,52 & 5,22 & 12,32 & 47,26 \\ \mathrm{Op} & 4,26 & 1,75 & 4,37 & 2,76 & 9,74 & 57,00 \\ \mathrm{Mir} & 3,03 & 1,00 & 3,55 & 2,56 & 7,92 & 64,92 \\ \mathrm{Do} & 0,00 & 1,60 & 2,81 & 1,33 & 6,27 & 71,19 \\ \mathrm{Br} & 2,13 & 0,90 & 2,79 & 1,91 & 6,22 & 77,41 \\ \mathrm{Mig} & 3,05 & 1,92 & 1,97 & 1,70 & 4,39 & 81,80 \\ \mathrm{Ag} & 4,42 & 3,51 & 1,62 & 1,75 & 3,62 & 85,42 \\ \mathrm{Ch} & 1,13 & 1,29 & 1,59 & 1,05 & 3,55 & 88,97 \\ & 2,38 & 2,33 & 1,41 & 1,10 & 3,14 & 92,12\end{array}$


Groups $3 \& 8$

Average dissimilarity $=43,50$

$$
\text { Group } 3 \text { Group } 8
$$

$\begin{array}{lrrrrrl}\text { Species } & \text { Av.Abund } & \text { Av.Abund } & \text { Av.Diss } & \text { Diss/SD } & \text { Contrib\% } & \text { Cum.\% } \\ \text { Aph } & 3,92 & 0,00 & 6,55 & 10,74 & 15,06 & 15,06 \\ \mathrm{Al} & 4,55 & 1,75 & 4,75 & 2,99 & 10,92 & 25,98 \\ \mathrm{Eu} & 3,82 & 1,13 & 4,45 & 7,44 & 10,23 & 36,21 \\ \mathrm{Op} & 3,02 & 1,00 & 3,35 & 3,97 & 7,69 & 43,90 \\ \mathrm{He} & 2,16 & 0,23 & 3,09 & 2,31 & 7,11 & 51,01 \\ \mathrm{Mir} & 0,00 & 1,60 & 2,71 & 1,30 & 6,22 & 57,24 \\ \mathrm{Br} & 3,46 & 1,92 & 2,56 & 2,27 & 5,87 & 63,11 \\ \mathrm{Ro} & 3,29 & 1,80 & 2,55 & 2,08 & 5,87 & 68,98 \\ \mathrm{Mig} & 5,03 & 3,51 & 2,48 & 2,32 & 5,69 & 74,67 \\ \mathrm{Ch} & 3,63 & 2,33 & 2,35 & 1,73 & 5,40 & 80,08 \\ \mathrm{Do} & 1,29 & 0,90 & 2,22 & 1,07 & 5,11 & 85,19 \\ \text { Hor } & 1,68 & 0,90 & 1,76 & 1,55 & 4,04 & 89,23 \\ \text { Ag } & 2,13 & 1,29 & 1,76 & 0,98 & 4,04 & 93,27\end{array}$

\section{Groups $4 \& 8$}

Average dissimilarity $=37,29$

$\begin{array}{lrrrrrl} & \text { Group 4 } & \text { Group } 8 & & & & \\ \text { Species } & \text { Av.Abund } & \text { Av.Abund } & \text { Av.Diss } & \text { Diss/SD } & \text { Contrib\% } & \text { Cum.\% } \\ \text { Aph } & 2,27 & 0,00 & 4,19 & 5,76 & 11,23 & 11,23 \\ \text { Eu } & 3,05 & 1,13 & 3,46 & 2,19 & 9,28 & 20,51 \\ \text { Al } & 3,34 & 1,75 & 3,14 & 1,34 & 8,41 & 28,92 \\ \text { Mir } & 0,00 & 1,60 & 3,03 & 1,32 & 8,14 & 37,06 \\ \text { Ag } & 2,33 & 1,29 & 2,97 & 1,80 & 7,97 & 45,03 \\ \text { Ch } & 3,85 & 2,33 & 2,93 & 1,73 & 7,87 & 52,90 \\ \text { Mig } & 4,99 & 3,51 & 2,80 & 2,71 & 7,50 & 60,39 \\ \text { Op } & 2,51 & 1,00 & 2,75 & 1,76 & 7,37 & 67,76 \\ \text { Do } & 1,36 & 0,90 & 2,58 & 1,18 & 6,93 & 74,68 \\ \text { Br } & 3,27 & 1,92 & 2,54 & 1,93 & 6,80 & 81,49 \\ \text { He } & 1,19 & 0,23 & 1,99 & 1,41 & 5,34 & 86,83 \\ \text { Ro } & 2,73 & 1,80 & 1,87 & 1,82 & 5,00 & 91,83\end{array}$

Groups $5 \& 8$

Average dissimilarity $=31,40$

$\begin{array}{lrrrrrl} & \text { Group 5 } & \text { Group 8 } & & & & \\ \text { Species } & \text { Av.Abund } & \text { Av.Abund } & \text { Av.Diss } & \text { Diss/SD } & \text { Contrib\% } & \text { Cum.\% } \\ \text { Mir } & 0,00 & 1,60 & 3,74 & 1,33 & 11,92 & 11,92 \\ \mathrm{He} & 1,52 & 0,23 & 3,01 & 3,06 & 9,60 & 21,51 \\ \mathrm{Ag} & 1,84 & 1,29 & 2,98 & 1,69 & 9,49 & 31,00\end{array}$




$\begin{array}{lllllll}\text { Do } & 0,77 & 0,90 & 2,76 & 1,30 & 8,78 & 39,79 \\ \text { Op } & 1,41 & 1,00 & 2,57 & 1,71 & 8,18 & 47,97 \\ \mathrm{Eu} & 2,19 & 1,13 & 2,48 & 1,75 & 7,91 & 55,88 \\ \mathrm{Al} & 1,79 & 1,75 & 2,07 & 1,05 & 6,58 & 62,46 \\ \mathrm{Ro} & 2,43 & 1,80 & 1,81 & 1,53 & 5,76 & 68,22 \\ \mathrm{Ch} & 2,65 & 2,33 & 1,78 & 1,29 & 5,67 & 73,90 \\ \mathrm{Br} & 2,38 & 1,92 & 1,73 & 1,69 & 5,50 & 79,39 \\ \mathrm{Aph} & 0,69 & 0,00 & 1,61 & 14,04 & 5,14 & 84,53 \\ \text { Mig } & 3,83 & 3,51 & 1,59 & 1,36 & 5,05 & 89,58 \\ \text { Hor } & 1,06 & 0,90 & 1,45 & 1,30 & 4,63 & 94,22\end{array}$

\section{Groups 6 \& 8}

Average dissimilarity $=31,22$

$$
\text { Group } 6 \text { Group } 8
$$

Species Av.Abund Av.Abund Av.Diss

Ag

Hom

Do

Mir

Al

Ro

$\mathrm{Ch}$

Mig

$\mathrm{Eu}$

$\mathrm{Br}$

Hor

Op

Aph

$$
2,32
$$$$
2,42
$$

0,83

1,17

2,31

2,74

3,01

4,30

2,04

2,48

0,69

0,83

0,73
1,29

1,06

0,90

1,60

1,75

1,80

2,33

3,51

1,13

1,92

0,90

1,00

0,00

3,96

2,96

2,62

2,61

2,39

2,28

2,01

1,86

1,84

1,83

1,60

1,46

1,42
Diss/SD

1,47

2,97

0,88

1,24

1,07

1,63

1,67

1,54

1,29

1,56

1,33

1,54

0,67
Contrib\% Cum.\%

$12,69 \quad 12,69$

$9,49 \quad 22,18$

$8,41 \quad 30,59$

$8,36 \quad 38,95$

$7,67 \quad 46,61$

$7,31 \quad 53,93$

$6,45 \quad 60,38$

$5,96 \quad 66,34$

$5,89 \quad 72,23$

$5,86 \quad 78,10$

$5,12 \quad 83,22$

$4,67 \quad 87,89$

$4,54 \quad 92,44$

Groups $7 \& 8$

Average dissimilarity $=31,72$

$\begin{array}{lrrrrrl} & \text { Group 7 } & \text { Group 8 } & & & & \\ \text { Species } & \text { Av.Abund } & \text { Av.Abund } & \text { Av.Diss } & \text { Diss/SD } & \text { Contrib\% } & \text { Cum.\% } \\ \text { Al } & 1,92 & 1,75 & 3,47 & 1,63 & 10,93 & 10,93 \\ \text { Ag } & 2,49 & 1,29 & 3,39 & 1,55 & 10,69 & 21,62 \\ \text { Hom } & 2,40 & 1,06 & 2,97 & 3,18 & 9,37 & 30,99 \\ \text { Do } & 1,16 & 0,90 & 2,91 & 1,64 & 9,17 & 40,16 \\ \text { Mir } & 1,07 & 1,60 & 2,70 & 1,62 & 8,52 & 48,68 \\ \text { Mig } & 4,57 & 3,51 & 2,27 & 1,84 & 7,17 & 55,85 \\ \text { Ch } & 2,60 & 2,33 & 2,15 & 1,22 & 6,78 & 62,63 \\ \text { Br } & 2,40 & 1,92 & 1,84 & 1,52 & 5,81 & 68,44 \\ \text { Ro } & 2,27 & 1,80 & 1,65 & 1,51 & 5,20 & 73,64\end{array}$




$\begin{array}{lllllll}\text { Hor } & 0,60 & 0,90 & 1,58 & 1,20 & 4,99 & 78,63 \\ \text { He } & 0,83 & 0,23 & 1,58 & 1,08 & 4,97 & 83,60 \\ \text { Aph } & 0,77 & 0,00 & 1,56 & 1,10 & 4,91 & 88,51 \\ \text { Eu } & 1,36 & 1,13 & 1,14 & 1,28 & 3,60 & 92,11\end{array}$

\section{Groups 1 \& 9}

Average dissimilarity $=35,49$

$\begin{array}{lrrrrrl} & \text { Group 1 } & \text { Group } 9 & & & & \\ \text { Species } & \text { Av.Abund } & \text { Av.Abund } & \text { Av.Diss } & \text { Diss/SD } & \text { Contrib\% } & \text { Cum.\% } \\ \text { Aph } & 5,18 & 1,44 & 7,22 & 2,53 & 20,34 & 20,34 \\ \text { Eu } & 3,46 & 0,77 & 5,16 & 2,90 & 14,55 & 34,89 \\ \mathrm{He} & 2,38 & 0,54 & 3,55 & 1,68 & 10,01 & 44,90 \\ \mathrm{Al} & 3,88 & 2,82 & 2,70 & 1,71 & 7,60 & 52,49 \\ \mathrm{Ag} & 0,46 & 1,60 & 2,44 & 1,75 & 6,89 & 59,38 \\ \mathrm{Ch} & 1,30 & 2,55 & 2,36 & 2,65 & 6,66 & 66,04 \\ \mathrm{Hom} & 2,33 & 1,67 & 1,98 & 1,06 & 5,59 & 71,63 \\ \mathrm{Mig} & 3,00 & 3,95 & 1,79 & 4,15 & 5,03 & 76,66 \\ \text { Do } & 0,83 & 0,96 & 1,76 & 1,52 & 4,96 & 81,63 \\ \mathrm{Br} & 2,19 & 2,47 & 1,58 & 1,59 & 4,44 & 86,07 \\ \text { Op } & 1,52 & 1,55 & 1,37 & 1,47 & 3,85 & 89,92 \\ \text { Mac } & 0,60 & 0,23 & 1,00 & 1,14 & 2,80 & 92,73\end{array}$

Groups $2 \& 9$

Average dissimilarity $=34,78$

$$
\text { Group } 2 \text { Group } 9
$$

Species Av.Abund Av.Abund

Aph

5,59

1,44

Av.Diss

Diss/SD

Contrib\%

Cum.\%

Eu

4,31

6,92

2,69

$19,90 \quad 19,90$

$\mathrm{He}$

0,77

5,87

3,69

$16,89 \quad 36,79$

Al

3,62

0,54

5,12

$14,72 \quad 51,51$

Op

4,26

2,82

3,41

$7,76 \quad 59,27$

Hom

3,03

2,70

1,56

$7,36 \quad 66,63$

Do

1,06

1,55

2,56

1,63

$6,37 \quad 73,00$

Ag

2,13

1,67

2,21

2,32

$6,19 \quad 79,19$

$\mathrm{Ch}$

1,13

2,15

1,61

$4,26 \quad 83,45$

$\mathrm{Br}$

2,38

1,60

1,30

4,07

87,52

1,41

3,38

$3,97 \quad 91,49$ 
Groups 3 \& 9

Average dissimilarity $=32,68$

$$
\text { Group } 3 \text { Group } 9
$$

$\begin{array}{lrrrrrl}\text { Species } & \text { Av.Abund } & \text { Av.Abund } & \text { Av.Diss } & \text { Diss/SD } & \text { Contrib\% } & \text { Cum.\% } \\ \text { Eu } & 3,82 & 0,77 & 4,84 & 3,77 & 14,82 & 14,82 \\ \text { Aph } & 3,92 & 1,44 & 3,98 & 1,74 & 12,18 & 27,00 \\ \text { Al } & 4,55 & 2,82 & 2,88 & 1,44 & 8,81 & 35,81 \\ \text { Ro } & 3,29 & 1,50 & 2,74 & 2,22 & 8,39 & 44,20 \\ \text { He } & 2,16 & 0,54 & 2,68 & 1,87 & 8,21 & 52,42 \\ \text { Op } & 3,02 & 1,55 & 2,31 & 1,69 & 7,08 & 59,49 \\ \text { Hom } & 1,73 & 1,67 & 2,00 & 1,39 & 6,13 & 65,62 \\ \text { Do } & 1,29 & 0,96 & 1,91 & 1,29 & 5,85 & 71,47 \\ \text { Ch } & 3,63 & 2,55 & 1,71 & 1,40 & 5,24 & 76,72 \\ \text { Br } & 3,46 & 2,47 & 1,65 & 1,36 & 5,05 & 81,76 \\ \text { Mig } & 5,03 & 3,95 & 1,65 & 2,35 & 5,04 & 86,80 \\ \text { Hor } & 1,68 & 0,69 & 1,45 & 1,23 & 4,43 & 91,23\end{array}$

Groups 4 \& 9

Average dissimilarity $=28,45$

$$
\text { Group } 4 \text { Group } 9
$$

$\begin{array}{lrrrrrl}\text { Species } & \text { Av.Abund } & \text { Av.Abund } & \text { Av.Diss } & \text { Diss/SD } & \text { Contrib\% } & \text { Cum.\% } \\ \mathrm{Eu} & 3,05 & 0,77 & 3,97 & 2,09 & 13,95 & 13,95 \\ \mathrm{Al} & 3,34 & 2,82 & 2,47 & 1,25 & 8,67 & 22,62 \\ \mathrm{Ag} & 2,33 & 1,60 & 2,35 & 1,65 & 8,26 & 30,88 \\ \mathrm{Ch} & 3,85 & 2,55 & 2,35 & 2,46 & 8,26 & 39,14 \\ \mathrm{Aph} & 2,27 & 1,44 & 2,31 & 1,38 & 8,11 & 47,25 \\ \mathrm{Ro} & 2,73 & 1,50 & 2,17 & 2,75 & 7,62 & 54,88 \\ \mathrm{Op} & 2,51 & 1,55 & 2,12 & 1,63 & 7,47 & 62,35 \\ \mathrm{Do} & 1,36 & 0,96 & 2,12 & 1,29 & 7,44 & 69,78 \\ \mathrm{Hom} & 1,93 & 1,67 & 2,01 & 1,38 & 7,05 & 76,84 \\ \mathrm{Mig} & 4,99 & 3,95 & 1,85 & 5,59 & 6,49 & 83,33 \\ \mathrm{He} & 1,19 & 0,54 & 1,83 & 1,21 & 6,44 & 89,77 \\ \mathrm{Br} & 3,27 & 2,47 & 1,71 & 1,33 & 6,01 & 95,78\end{array}$

Groups 5 \& 9

Average dissimilarity $=28,70$

Group 5 Group 9

$\begin{array}{lrrrrrl}\text { Species } & \text { Av.Abund } & \text { Av.Abund } & \text { Av.Diss } & \text { Diss/SD } & \text { Contrib\% } & \text { Cum.\% } \\ \text { Al } & 1,79 & 2,82 & 3,26 & 1,55 & 11,36 & 11,36 \\ \text { Eu } & 2,19 & 0,77 & 3,17 & 1,69 & 11,05 & 22,41 \\ \text { Hom } & 0,92 & 1,67 & 2,99 & 1,62 & 10,41 & 32,82 \\ \text { Aph } & 0,69 & 1,44 & 2,56 & 1,67 & 8,93 & 41,75\end{array}$




$\begin{array}{lllllll}\text { Op } & 1,41 & 1,55 & 2,49 & 1,38 & 8,67 & 50,42 \\ \mathrm{He} & 1,52 & 0,54 & 2,40 & 1,56 & 8,36 & 58,78 \\ \mathrm{Ag} & 1,84 & 1,60 & 2,31 & 1,58 & 8,05 & 66,84 \\ \mathrm{Ro} & 2,43 & 1,50 & 2,01 & 1,88 & 7,01 & 73,85 \\ \mathrm{Do} & 0,77 & 0,96 & 1,96 & 1,29 & 6,82 & 80,66 \\ \mathrm{Br} & 2,38 & 2,47 & 1,81 & 1,65 & 6,31 & 86,97 \\ \mathrm{Ch} & 2,65 & 2,55 & 1,16 & 1,58 & 4,05 & 91,02\end{array}$

\section{Groups $6 \& 9$}

Average dissimilarity $=30,43$

$$
\text { Group } 6 \text { Group } 9
$$

Species Av.Abund Av.Abund

Ag

$2,32 \quad 1,60$

Av.Diss

Diss/SD

$\begin{array}{cl}\text { Contrib\% } & \text { Cum.\% } \\ 11,63 & 11,63\end{array}$

$\mathrm{Al}$

$$
2,31
$$

2,82

3,54

1,75

Aph

$$
0,73
$$

1,44

2,87

1,32

$9,44 \quad 21,07$

$\mathrm{Eu}$

2,04

0,77

2,74

1,20

$9,00 \quad 30,08$

Mir

1,17

2,53

1,36

$8,30 \quad 38,38$

Ro

2,74

0,00

2,50

1,10

$8,22 \quad 46,60$

Do

$$
0,83
$$

1,50

2,44

1,71

$8,02 \quad 54,62$

Hom

2,42

0,96

2,36

1,15

7,75

62,38

Op

0,83

1,67

2,16

1,08

7,09

69,47

$\mathrm{Br}$

2,48

1,55

1,95

1,21

$6,41 \quad 75,88$

$\mathrm{He}$

2,47

1,75

1,54

$5,76 \quad 81,64$

$\mathrm{Ch}$

0,69

0,54

1,58

1,27

$5,19 \quad 86,83$

1,05

1,19

3,4

90,28

Groups $7 \& 9$

Average dissimilarity $=28,93$

$$
\text { Group } 7 \text { Group } 9
$$

Species Av.Abund Av.Abun

Al

$$
1,92
$$

$$
2,82
$$

Av.Diss

Diss/SD

Contrib\%

Cum.\%

Ag

2,49

1,60

3,73

1,24

$12,88 \quad 12,88$

Aph

0,77

1,44

2,65

1,48

$9,17 \quad 22,06$

Mir

1,07

0,00

2,52

1,24

$8,72 \quad 30,78$

Hom

2,40

1,67

2,31

1,31

$7,97 \quad 38,75$

$\mathrm{Ch}$

2,60

2,55

2,19

1,10

$7,55 \quad 46,30$

$\mathrm{Br}$

2,40

2,47

1,97

2,18

$6,82 \quad 53,13$

Do

1,16

1,90

1,50

$6,56 \quad 59,68$

$\mathrm{He}$

0,83

0,96

1,85

1,10

$6,39 \quad 66,08$

$\mathrm{Eu}$

1,36

0,54

1,70

1,13

$5,89 \quad 71,96$

$\mathrm{Eu}$

2,27

0,77

1,70

1,15

$5,86 \quad 77,83$

Ro

1,19

1,50

1,60

1,42

$5,54 \quad 83,37$

Op

4,57

1,55

1,58

1,25

$5,47 \quad 88,84$

Mig

3,95

1,21

2,01

$4,18 \quad 93,02$ 
Groups 8 \& 9

Average dissimilarity $=32,43$

$\begin{array}{lrrrrrl} & \text { Group 8 } & \text { Group 9 } & & & & \\ \text { Species } & \text { Av.Abund } & \text { Av.Abund } & \text { Av.Diss } & \text { Diss/SD } & \text { Contrib\% } & \text { Cum.\% } \\ \text { Mir } & 1,60 & 0,00 & 3,83 & 1,33 & 11,81 & 11,81 \\ \text { Aph } & 0,00 & 1,44 & 3,27 & 1,15 & 10,09 & 21,90 \\ \text { Al } & 1,75 & 2,82 & 3,22 & 1,39 & 9,93 & 31,83 \\ \text { Hom } & 1,06 & 1,67 & 3,19 & 2,28 & 9,84 & 41,67 \\ \text { Do } & 0,90 & 0,96 & 2,94 & 1,19 & 9,07 & 50,74 \\ \text { Br } & 1,92 & 2,47 & 2,34 & 1,23 & 7,20 & 57,95 \\ \mathrm{Ag} & 1,29 & 1,60 & 2,23 & 1,19 & 6,88 & 64,83 \\ \text { Op } & 1,00 & 1,55 & 1,87 & 1,18 & 5,75 & 70,58 \\ \text { Eu } & 1,13 & 0,77 & 1,68 & 1,22 & 5,18 & 75,76 \\ \text { Ch } & 2,33 & 2,55 & 1,65 & 3,33 & 5,08 & 80,84 \\ \text { Hor } & 0,90 & 0,69 & 1,60 & 2,98 & 4,94 & 85,77 \\ \text { He } & 0,23 & 0,54 & 1,40 & 0,92 & 4,31 & 90,09\end{array}$


Appendix F.

Year 2013

SIMPER - Similarity Percentages

Subfamilies contributions

\section{Parameters}

Resemblance: Bray Curtis similarity

Cut off for low contributions: $90,00 \%$

\section{Factor Groups}

Sample Vineyard

C1 C

$\mathrm{C} 2 \quad \mathrm{C}$

$\mathrm{C} 3 \mathrm{C}$

$\mathrm{C} 4 \mathrm{C}$

C5 $\mathrm{C}$

C6 $\mathrm{C}$

$\mathrm{C} 7 \mathrm{C}$

C8 C

C9 $\quad \mathrm{C}$

$\mathrm{C} 10 \quad \mathrm{C}$

MD1 MD

MD2 MD

MD3 MD

MD4 MD

MD5 MD

MD6 MD

MD7 MD

MD8 MD

MD9 MD

MD10 MD

O1 O

$\mathrm{O} 2 \mathrm{O}$

$\mathrm{O} 3 \mathrm{O}$

O4 O

O5 O

O6 O

O7 O

O8 O

O9 O

O10 O 


\section{Group C}

Average similarity: 71,01

$\begin{array}{lrrrrl}\text { Species } & \text { Av.Abund } & \text { Av.Sim } & \text { Sim/SD } & \text { Contrib\% } & \text { Cum.\% } \\ \text { Mig } & 3,91 & 15,31 & 7,37 & 21,56 & 21,56 \\ \text { Al } & 2,60 & 8,80 & 3,06 & 12,40 & 33,96 \\ \text { Br } & 2,41 & 8,64 & 3,14 & 12,17 & 46,13 \\ \text { Aph } & 2,05 & 6,94 & 2,69 & 9,78 & 55,91 \\ \text { Ro } & 1,72 & 5,61 & 2,27 & 7,90 & 63,80 \\ \text { Eu } & 1,69 & 4,98 & 2,00 & 7,01 & 70,82 \\ \text { Ch } & 1,76 & 4,88 & 1,31 & 6,87 & 77,69 \\ \text { He } & 1,31 & 4,16 & 1,68 & 5,86 & 83,55 \\ \text { Hom } & 1,70 & 4,14 & 1,41 & 5,83 & 89,38 \\ \text { Op } & 1,44 & 3,85 & 1,51 & 5,42 & 94,79\end{array}$

\section{Group MD}

Average similarity: 70,76

$\begin{array}{lrrrrl}\text { Species } & \text { Av.Abund } & \text { Av.Sim } & \text { Sim/SD } & \text { Contrib\% } & \text { Cum.\% } \\ \text { Al } & 3,93 & 15,77 & 9,90 & 22,28 & 22,28 \\ \text { Mig } & 3,68 & 14,70 & 6,42 & 20,77 & 43,05 \\ \text { Aph } & 2,82 & 8,00 & 1,89 & 11,30 & 54,35 \\ \text { Ag } & 1,81 & 5,57 & 1,76 & 7,87 & 62,22 \\ \text { Eu } & 2,02 & 4,84 & 1,09 & 6,84 & 69,06 \\ \text { Op } & 1,67 & 4,58 & 1,52 & 6,47 & 75,54 \\ \text { Br } & 1,51 & 4,51 & 2,48 & 6,38 & 81,91 \\ \text { Ro } & 1,25 & 3,25 & 1,12 & 4,59 & 86,51 \\ \text { Hom } & 1,18 & 2,81 & 0,81 & 3,97 & 90,47\end{array}$

Group $O$

Average similarity: 65,27

$\begin{array}{lrrrrl}\text { Species } & \text { Av.Abund } & \text { Av.Sim } & \text { Sim/SD } & \text { Contrib\% } & \text { Cum.\% } \\ \text { Mig } & 3,92 & 16,62 & 4,11 & 25,46 & 25,46 \\ \mathrm{Br} & 2,35 & 9,10 & 3,84 & 13,94 & 39,40 \\ \mathrm{Ch} & 2,19 & 7,50 & 2,56 & 11,48 & 50,88 \\ \mathrm{Al} & 1,97 & 6,03 & 2,73 & 9,24 & 60,12 \\ \mathrm{Ro} & 1,65 & 5,22 & 1,59 & 8,00 & 68,12 \\ \mathrm{Hom} & 1,92 & 4,75 & 0,95 & 7,28 & 75,40 \\ \text { Op } & 1,40 & 3,28 & 1,15 & 5,03 & 80,43 \\ \mathrm{Aph} & 1,61 & 2,74 & 0,65 & 4,20 & 84,62 \\ \text { Eu } & 1,58 & 2,50 & 0,64 & 3,83 & 88,45 \\ \text { Do } & 0,90 & 2,32 & 1,15 & 3,55 & 92,00\end{array}$


Groups $C \& M D$

Average dissimilarity $=32,48$

Group C Group MD

$\begin{array}{lrrrrrr}\text { Species } & \text { Av.Abund } & \text { Av.Abund } & \text { Av.Diss } & \text { Diss/SD } & \text { Contrib\% } & \text { Cum.\% } \\ \text { Aph } & 2,05 & 2,82 & 3,17 & 1,53 & 9,77 & 9,77 \\ \mathrm{Ag} & 0,51 & 1,81 & 3,07 & 1,72 & 9,46 & 19,23 \\ \mathrm{Al} & 2,60 & 3,93 & 3,07 & 1,55 & 9,45 & 28,68 \\ \mathrm{Eu} & 1,69 & 2,02 & 2,97 & 1,51 & 9,14 & 37,83 \\ \mathrm{Hom} & 1,70 & 1,18 & 2,73 & 1,25 & 8,42 & 46,24 \\ \mathrm{Ch} & 1,76 & 1,11 & 2,56 & 1,44 & 7,89 & 54,14 \\ \mathrm{Br} & 2,41 & 1,51 & 2,51 & 1,44 & 7,73 & 61,87 \\ \mathrm{Op} & 1,44 & 1,67 & 2,27 & 1,42 & 6,99 & 68,86 \\ \mathrm{Ro} & 1,72 & 1,25 & 1,99 & 1,28 & 6,13 & 74,99 \\ \mathrm{He} & 1,31 & 0,92 & 1,54 & 1,38 & 4,73 & 79,72 \\ \mathrm{Mig} & 3,91 & 3,68 & 1,52 & 1,30 & 4,68 & 84,40 \\ \text { Mac } & 0,66 & 0,14 & 1,41 & 1,12 & 4,33 & 88,74 \\ \text { Hor } & 0,46 & 0,43 & 1,16 & 1,21 & 3,58 & 92,32\end{array}$

Groups $C \& O$

Average dissimilarity $=32,02$

$\begin{array}{lrrrrrl}\text { Species } & \text { Group C } & \text { Group O } & & & & \\ \text { Av.Abund } & \text { Av.Abund } & \text { Av.Diss } & \text { Diss/SD } & \text { Contrib\% } & \text { Cum.\% } \\ \text { Eu } & 1,70 & 1,92 & 3,45 & 1,33 & 10,78 & 10,78 \\ \mathrm{Aph} & 1,69 & 1,58 & 3,41 & 1,55 & 10,64 & 21,42 \\ \mathrm{Al} & 2,05 & 1,61 & 3,37 & 1,69 & 10,51 & 31,93 \\ \mathrm{Ch} & 2,60 & 1,97 & 2,70 & 1,34 & 8,44 & 40,37 \\ \mathrm{Op} & 1,76 & 2,19 & 2,48 & 1,30 & 7,75 & 48,12 \\ \mathrm{He} & 1,44 & 1,40 & 2,27 & 1,31 & 7,10 & 55,21 \\ \mathrm{Ro} & 1,31 & 0,99 & 1,99 & 1,39 & 6,21 & 61,42 \\ \mathrm{Ag} & 1,72 & 1,65 & 1,86 & 1,23 & 5,81 & 67,23 \\ \mathrm{Br} & 0,51 & 0,92 & 1,81 & 1,17 & 5,65 & 72,88 \\ \mathrm{Do} & 2,41 & 2,35 & 1,61 & 1,25 & 5,01 & 77,89 \\ \mathrm{Mig} & 0,28 & 0,90 & 1,59 & 1,37 & 4,95 & 82,85 \\ \mathrm{Mac} & 3,91 & 3,92 & 1,57 & 1,40 & 4,90 & 87,75 \\ & 0,66 & 0,46 & 1,35 & 1,22 & 4,20 & 91,95\end{array}$

Groups $M D \& O$

Average dissimilarity $=36,71$

Group MD Group O

Species Av.Abund Av.Abund

$\begin{array}{lllllll}\text { Al } & 3,93 & 1,97 & 4,49 & 1,74 & 12,22 & 12,22 \\ \text { Aph } & 2,82 & 1,61 & 4,47 & 1,47 & 12,17 & 24,39\end{array}$




$\begin{array}{lrrrrrr}\text { Eu } & 2,02 & 1,58 & 3,92 & 1,42 & 10,67 & 35,07 \\ \mathrm{Hom} & 1,18 & 1,92 & 3,29 & 1,29 & 8,97 & 44,03 \\ \mathrm{Ch} & 1,11 & 2,19 & 2,90 & 1,43 & 7,89 & 51,92 \\ \mathrm{Ag} & 1,81 & 0,92 & 2,75 & 1,64 & 7,49 & 59,41 \\ \mathrm{Op} & 1,67 & 1,40 & 2,41 & 1,35 & 6,58 & 65,99 \\ \mathrm{Br} & 1,51 & 2,35 & 2,28 & 1,47 & 6,21 & 72,20 \\ \mathrm{Ro} & 1,25 & 1,65 & 2,08 & 1,28 & 5,66 & 77,86 \\ \mathrm{He} & 0,92 & 0,99 & 1,75 & 1,35 & 4,77 & 82,63 \\ \mathrm{Do} & 0,39 & 0,90 & 1,51 & 1,32 & 4,10 & 86,73 \\ \mathrm{Mig} & 3,68 & 3,92 & 1,34 & 1,22 & 3,66 & 90,39\end{array}$


Appendix G.

Year 2013

SIMPER - Similarity Percentages

Subfamilies contributions

\section{Parameters}

Resemblance: Bray Curtis similarity

Cut off for low contributions: $90,00 \%$

\section{Factor Groups}

Sample Time

C1 1

MD1 1

O1 1

$\mathrm{C} 2 \quad 2$

MD2 2

O2 2

C3 3

MD3 3

O3 3

$\mathrm{C} 4 \quad 4$

MD4 4

O4 4

C5 5

MD5 5

O5 5

C6 6

MD6 6

O6 6

C7 7

MD7 7

O7 $\quad 7$

C8 8

MD8 8

O8 8

C9 $\quad 9$

MD9 9

O9 9

C10 10

MD10 10

O10 10 
Group 1

Average similarity: 73,86

$\begin{array}{lrrrrl}\text { Species } & \text { Av.Abund } & \text { Av.Sim } & \text { Sim/SD } & \text { Contrib\% } & \text { Cum.\% } \\ \text { Al } & 3,40 & 16,55 & 17,63 & 22,41 & 22,41 \\ \text { Mig } & 2,77 & 13,93 & 12,30 & 18,86 & 41,27 \\ \text { Eu } & 3,04 & 12,66 & 3,21 & 17,15 & 58,42 \\ \text { Aph } & 2,92 & 12,10 & 6,89 & 16,39 & 74,81 \\ \mathrm{He} & 1,39 & 4,86 & 2,07 & 6,57 & 81,38 \\ \mathrm{Br} & 0,96 & 4,33 & 3,00 & 5,87 & 87,25 \\ \mathrm{Mac} & 1,06 & 4,33 & 3,00 & 5,87 & 93,11\end{array}$

Group 2

Average similarity: 80,09

$\begin{array}{lrrrrl}\text { Species } & \text { Av.Abund } & \text { Av.Sim } & \text { Sim/SD } & \text { Contrib\% } & \text { Cum.\% } \\ \text { Al } & 3,75 & 13,69 & 8,50 & 17,10 & 17,10 \\ \text { Mig } & 3,27 & 12,73 & 52,22 & 15,90 & 33,00 \\ \text { Aph } & 3,59 & 12,26 & 9,63 & 15,31 & 48,31 \\ \text { Eu } & 3,31 & 11,30 & 3,83 & 14,11 & 62,42 \\ \text { Op } & 2,52 & 9,56 & 112,81 & 11,93 & 74,36 \\ \text { Br } & 1,75 & 5,70 & 2,91 & 7,12 & 81,48 \\ \mathrm{He} & 1,50 & 5,16 & 3,73 & 6,45 & 87,92 \\ \text { Hom } & 1,16 & 3,69 & 2,64 & 4,61 & 92,53\end{array}$

Group 3

Average similarity: 80,65

Species Av.Abund

Av.Sim Sim/SD Contrib\% Cum.\%

$\begin{array}{lrrrrr}\text { Al } & 4,17 & 11,77 & 8,79 & 14,59 & 14,59 \\ \text { Eu } & 3,89 & 11,71 & 23,50 & 14,53 & 29,12 \\ \text { Mig } & 3,91 & 11,57 & 30,77 & 14,35 & 43,47 \\ \text { Aph } & 4,12 & 10,93 & 8,39 & 13,56 & 57,03 \\ \text { Op } & 3,08 & 9,22 & 19,77 & 11,43 & 68,46 \\ \text { Br } & 2,76 & 8,15 & 6,41 & 10,10 & 78,56 \\ \text { Ch } & 1,94 & 5,83 & 47,03 & 7,23 & 85,80 \\ \text { Ro } & 1,93 & 5,21 & 4,27 & 6,46 & 92,26\end{array}$

Group 4

Average similarity: 79,94

$\begin{array}{lrrrrl}\text { Species } & \text { Av.Abund } & \text { Av.Sim } & \text { Sim/SD } & \text { Contrib\% } & \text { Cum.\% } \\ \text { Mig } & 3,80 & 13,69 & 125,60 & 17,12 & 17,12 \\ \text { Aph } & 3,17 & 10,10 & 70,60 & 12,64 & 29,76 \\ \text { Al } & 3,16 & 9,04 & 2,93 & 11,31 & 41,07 \\ \text { Ch } & 2,69 & 8,98 & 16,34 & 11,23 & 52,30\end{array}$




$\begin{array}{lrrrrr}\mathrm{Eu} & 2,33 & 8,73 & 8,33 & 10,92 & 63,23 \\ \mathrm{Br} & 2,39 & 6,79 & 3,27 & 8,50 & 71,72 \\ \mathrm{Op} & 1,92 & 6,59 & 39,68 & 8,24 & 79,96 \\ \mathrm{Do} & 1,06 & 3,14 & 5,29 & 3,93 & 83,89 \\ \mathrm{Ro} & 1,36 & 3,14 & 5,29 & 3,93 & 87,82 \\ \mathrm{He} & 0,92 & 2,67 & 11,98 & 3,34 & 91,15\end{array}$

\section{Group 5}

Average similarity: 70,76

$\begin{array}{lrrrrl}\text { Species } & \text { Av.Abund } & \text { Av.Sim } & \text { Sim/SD } & \text { Contrib\% } & \text { Cum.\% } \\ \text { Mig } & 3,95 & 15,81 & 6,95 & 22,34 & 22,34 \\ \text { Br } & 2,38 & 9,71 & 9,86 & 13,72 & 36,07 \\ \text { Aph } & 2,50 & 8,84 & 6,14 & 12,49 & 48,56 \\ \text { Ro } & 2,12 & 7,91 & 5,63 & 11,18 & 59,74 \\ \text { Al } & 2,48 & 6,77 & 2,11 & 9,57 & 69,30 \\ \text { Ch } & 2,06 & 6,40 & 2,39 & 9,05 & 78,35 \\ \text { He } & 1,66 & 6,09 & 19,54 & 8,60 & 86,95 \\ \text { Op } & 1,70 & 5,54 & 5,09 & 7,83 & 94,78\end{array}$

\section{Group 6}

Average similarity: 73,39

$\begin{array}{lrrrrl}\text { Species } & \text { Av.Abund } & \text { Av.Sim } & \text { Sim/SD } & \text { Contrib\% } & \text { Cum.\% } \\ \text { Mig } & 3,97 & 19,61 & 15,96 & 26,72 & 26,72 \\ \text { Br } & 2,52 & 11,03 & 6,83 & 15,03 & 41,76 \\ \text { Ro } & 1,93 & 9,02 & 15,81 & 12,28 & 54,04 \\ \text { Al } & 2,15 & 6,33 & 5,59 & 8,63 & 62,67 \\ \text { Aph } & 1,29 & 5,98 & 10,98 & 8,15 & 70,82 \\ \text { Ch } & 1,57 & 5,73 & 1,40 & 7,81 & 78,63 \\ \text { He } & 1,29 & 4,73 & 2,01 & 6,44 & 85,07 \\ \text { Hom } & 1,29 & 4,64 & 2,34 & 6,32 & 91,39\end{array}$

Group 7

Average similarity: 64,92

$\begin{array}{lrrrrl}\text { Species } & \text { Av.Abund } & \text { Av.Sim } & \text { Sim/SD } & \text { Contrib\% } & \text { Cum.\% } \\ \text { Mig } & 4,14 & 22,03 & 7,25 & 33,93 & 33,93 \\ \mathrm{Br} & 2,22 & 9,44 & 4,70 & 14,54 & 48,47 \\ \text { Ro } & 1,52 & 5,56 & 2,03 & 8,56 & 57,03 \\ \text { Hom } & 1,62 & 5,45 & 1,86 & 8,39 & 65,42 \\ \mathrm{Ch} & 1,16 & 5,16 & 1,88 & 7,95 & 73,37 \\ \mathrm{Al} & 1,82 & 4,43 & 5,46 & 6,83 & 80,20 \\ \mathrm{Eu} & 1,06 & 4,43 & 5,46 & 6,83 & 87,03 \\ \mathrm{Ag} & 1,06 & 2,00 & 0,58 & 3,08 & 90,12\end{array}$


Group 8

Average similarity: 69,34

$\begin{array}{lrrrrl}\text { Species } & \text { Av.Abund } & \text { Av.Sim } & \text { Sim/SD } & \text { Contrib\% } & \text { Cum.\% } \\ \text { Mig } & 4,30 & 18,62 & 8,84 & 26,86 & 26,86 \\ \text { Ro } & 2,11 & 9,32 & 8,78 & 13,45 & 40,30 \\ \text { Hom } & 2,21 & 8,85 & 7,07 & 12,76 & 53,06 \\ \text { Al } & 2,65 & 8,23 & 3,43 & 11,87 & 64,93 \\ \text { Ch } & 2,34 & 7,98 & 1,59 & 11,51 & 76,44 \\ \mathrm{Br} & 2,04 & 5,80 & 1,30 & 8,36 & 84,80 \\ \mathrm{Ag} & 1,43 & 4,21 & 3,10 & 6,07 & 90,87\end{array}$

Group 9

Average similarity: 73,56

$\begin{array}{lrrrrl}\text { Species } & \text { Av.Abund } & \text { Av.Sim } & \text { Sim/SD } & \text { Contrib\% } & \text { Cum.\% } \\ \text { Mig } & 4,35 & 18,33 & 19,06 & 24,91 & 24,91 \\ \text { Hom } & 3,24 & 13,09 & 6,87 & 17,80 & 42,72 \\ \text { Ch } & 2,71 & 10,51 & 7,82 & 14,29 & 57,00 \\ \text { Al } & 2,33 & 8,31 & 6,81 & 11,30 & 68,30 \\ \text { Br } & 1,80 & 5,73 & 1,46 & 7,79 & 76,09 \\ \text { Ro } & 1,43 & 4,37 & 2,80 & 5,94 & 82,03 \\ \text { Ag } & 0,83 & 3,34 & 14,68 & 4,54 & 86,57 \\ \text { Eu } & 1,00 & 3,34 & 14,68 & 4,54 & 91,11\end{array}$

Group 10

Average similarity: 73,82

$\begin{array}{lrrrrl}\text { Species } & \text { Av.Abund } & \text { Av.Sim } & \text { Sim/SD } & \text { Contrib\% } & \text { Cum.\% } \\ \text { Mig } & 3,93 & 15,23 & 18,25 & 20,64 & 20,64 \\ \text { Hom } & 3,88 & 13,08 & 4,11 & 17,73 & 38,36 \\ \text { Al } & 2,40 & 8,39 & 9,53 & 11,37 & 49,73 \\ \text { Ag } & 2,27 & 7,77 & 4,01 & 10,53 & 60,26 \\ \text { Br } & 2,08 & 6,17 & 2,63 & 8,36 & 68,62 \\ \text { Ro } & 1,85 & 5,28 & 6,56 & 7,15 & 75,77 \\ \text { Op } & 1,36 & 4,99 & 15,91 & 6,77 & 82,54 \\ \text { Eu } & 1,06 & 3,52 & 2,93 & 4,77 & 87,31 \\ \text { Ch } & 1,40 & 3,50 & 3,20 & 4,74 & 92,05\end{array}$

Groups $1 \& 2$

Average dissimilarity $=24,40$

Group $1 \quad$ Group 2

$\begin{array}{lrrrrrl}\text { Species } & \text { Av.Abund } & \text { Av.Abund } & \text { Av.Diss } & \text { Diss/SD } & \text { Contrib\% } & \text { Cum.\% } \\ \text { Op } & 1,13 & 2,52 & 3,22 & 1,49 & 13,18 & 13,18 \\ \text { Aph } & 2,92 & 3,59 & 2,31 & 1,20 & 9,46 & 22,64\end{array}$




$\begin{array}{llllrrr}\text { Eu } & 3,04 & 3,31 & 1,88 & 1,11 & 7,69 & 30,33 \\ \text { Ro } & 0,23 & 0,90 & 1,83 & 1,42 & 7,49 & 37,82 \\ \mathrm{Br} & 0,96 & 1,75 & 1,74 & 1,52 & 7,11 & 44,93 \\ \mathrm{Do} & 0,00 & 0,69 & 1,58 & 15,18 & 6,47 & 51,41 \\ \mathrm{Hom} & 0,77 & 1,16 & 1,54 & 1,46 & 6,31 & 57,72 \\ \mathrm{Ch} & 0,23 & 0,77 & 1,53 & 1,11 & 6,29 & 64,01 \\ \mathrm{Mac} & 1,06 & 0,46 & 1,42 & 1,22 & 5,82 & 69,83 \\ \mathrm{Met} & 0,37 & 0,46 & 1,31 & 0,91 & 5,35 & 75,18 \\ \mathrm{Ag} & 0,46 & 0,37 & 1,30 & 0,91 & 5,31 & 80,49 \\ \mathrm{He} & 1,39 & 1,50 & 1,26 & 1,76 & 5,18 & 85,67 \\ \mathrm{Al} & 3,40 & 3,75 & 1,19 & 1,12 & 4,88 & 90,55\end{array}$

Groups $1 \& 3$

Average dissimilarity $=33,09$

$\begin{array}{lrrrrrl} & \text { Group 1 } & \text { Group 3 } & & & & \\ \text { Species } & \text { Av.Abund } & \text { Av.Abund } & \text { Av.Diss } & \text { Diss/SD } & \text { Contrib\% } & \text { Cum.\% } \\ \text { Op } & 1,13 & 3,08 & 3,87 & 2,05 & 11,70 & 11,70 \\ \text { Br } & 0,96 & 2,76 & 3,56 & 4,62 & 10,75 & 22,45 \\ \text { Ch } & 0,23 & 1,94 & 3,36 & 4,68 & 10,15 & 32,60 \\ \text { Ro } & 0,23 & 1,93 & 3,29 & 3,69 & 9,93 & 42,53 \\ \text { Ag } & 0,46 & 1,42 & 2,70 & 1,05 & 8,17 & 50,70 \\ \text { Aph } & 2,92 & 4,12 & 2,62 & 1,48 & 7,92 & 58,62 \\ \text { Mig } & 2,77 & 3,91 & 2,22 & 3,68 & 6,70 & 65,32 \\ \text { Eu } & 3,04 & 3,89 & 1,76 & 1,02 & 5,31 & 70,62 \\ \text { Do } & 0,00 & 0,88 & 1,70 & 1,01 & 5,13 & 75,75 \\ \text { Al } & 3,40 & 4,17 & 1,63 & 1,52 & 4,94 & 80,69 \\ \text { Hom } & 0,77 & 0,46 & 1,53 & 1,20 & 4,62 & 85,31 \\ \text { He } & 1,39 & 1,76 & 1,48 & 1,46 & 4,46 & 89,77 \\ \text { Mac } & 1,06 & 0,60 & 1,07 & 1,20 & 3,23 & 93,00\end{array}$

Groups 2 \& 3

Average dissimilarity $=20,86$

$$
\text { Group } 2 \text { Group } 3
$$

$\begin{array}{lrrrrrl}\text { Species } & \text { Av.Abund } & \text { Av.Abund } & \text { Av.Diss } & \text { Diss/SD } & \text { Contrib\% } & \text { Cum.\% } \\ \mathrm{Ag} & 0,37 & 1,42 & 2,39 & 0,99 & 11,45 & 11,45 \\ \mathrm{Ch} & 0,77 & 1,94 & 2,12 & 1,59 & 10,14 & 21,59 \\ \mathrm{Ro} & 0,90 & 1,93 & 1,93 & 1,40 & 9,25 & 30,84 \\ \mathrm{Br} & 1,75 & 2,76 & 1,85 & 1,65 & 8,85 & 39,68 \\ \mathrm{Aph} & 3,59 & 4,12 & 1,72 & 1,41 & 8,25 & 47,93 \\ \mathrm{Hom} & 1,16 & 0,46 & 1,47 & 1,53 & 7,05 & 54,98 \\ \mathrm{Al} & 3,75 & 4,17 & 1,21 & 1,48 & 5,80 & 60,78 \\ \mathrm{Eu} & 3,31 & 3,89 & 1,20 & 1,08 & 5,76 & 66,55\end{array}$




$\begin{array}{lllllll}\text { Do } & 0,69 & 0,88 & 1,17 & 1,22 & 5,63 & 72,17 \\ \text { Mig } & 3,27 & 3,91 & 1,12 & 1,69 & 5,37 & 77,54 \\ \text { He } & 1,50 & 1,76 & 0,99 & 1,20 & 4,76 & 82,31 \\ \text { Op } & 2,52 & 3,08 & 0,99 & 1,79 & 4,75 & 87,05 \\ \text { Met } & 0,46 & 0,23 & 0,94 & 0,92 & 4,52 & 91,57\end{array}$

Groups $1 \& 4$

Average dissimilarity $=34,82$

Group $1 \quad$ Group 4

$\begin{array}{lrrrrrl}\text { Species } & \text { Av.Abund } & \text { Av.Abund } & \text { Av.Diss } & \text { Diss/SD } & \text { Contrib\% } & \text { Cum.\% } \\ \text { Ch } & 0,23 & 2,69 & 5,41 & 4,49 & 15,53 & 15,53 \\ \mathrm{Br} & 0,96 & 2,39 & 3,01 & 1,90 & 8,64 & 24,17 \\ \mathrm{Ro} & 0,23 & 1,36 & 2,39 & 1,50 & 6,87 & 31,04 \\ \mathrm{Mac} & 1,06 & 0,00 & 2,38 & 2,96 & 6,83 & 37,87 \\ \mathrm{Do} & 0,00 & 1,06 & 2,30 & 4,57 & 6,61 & 44,48 \\ \mathrm{Mig} & 2,77 & 3,80 & 2,23 & 4,12 & 6,42 & 50,89 \\ \mathrm{Eu} & 3,04 & 2,33 & 2,10 & 2,27 & 6,03 & 56,92 \\ \mathrm{Ag} & 0,46 & 1,07 & 1,99 & 1,18 & 5,70 & 62,62 \\ \mathrm{Al} & 3,40 & 3,16 & 1,98 & 1,68 & 5,69 & 68,32 \\ \mathrm{Op} & 1,13 & 1,92 & 1,86 & 0,95 & 5,35 & 73,67 \\ \mathrm{Aph} & 2,92 & 3,17 & 1,82 & 1,35 & 5,23 & 78,89 \\ \mathrm{Hor} & 0,00 & 0,83 & 1,82 & 4,92 & 5,22 & 84,12 \\ \text { Hom } & 0,77 & 0,92 & 1,71 & 1,25 & 4,90 & 89,01 \\ \text { He } & 1,39 & 0,92 & 1,35 & 1,18 & 3,87 & 92,88\end{array}$

Groups 2 \& 4

Average dissimilarity $=24,48$

$\begin{array}{lrrrrrl} & \text { Group 2 } & \text { Group 4 } & & & & \\ \text { Species } & \text { Av.Abund } & \text { Av.Abund } & \text { Av.Diss } & \text { Diss/SD } & \text { Contrib\% } & \text { Cum.\% } \\ \text { Ch } & 0,77 & 2,69 & 3,81 & 2,18 & 15,57 & 15,57 \\ \mathrm{Al} & 3,75 & 3,16 & 2,05 & 1,42 & 8,39 & 23,95 \\ \mathrm{Eu} & 3,31 & 2,33 & 1,93 & 1,39 & 7,90 & 31,85 \\ \mathrm{Br} & 1,75 & 2,39 & 1,84 & 1,73 & 7,52 & 39,37 \\ \mathrm{Ag} & 0,37 & 1,07 & 1,83 & 1,35 & 7,46 & 46,83 \\ \mathrm{Aph} & 3,59 & 3,17 & 1,78 & 1,20 & 7,27 & 54,10 \\ \mathrm{Ro} & 0,90 & 1,36 & 1,72 & 1,36 & 7,03 & 61,14 \\ \mathrm{Hor} & 0,00 & 0,83 & 1,63 & 4,83 & 6,64 & 67,78 \\ \mathrm{He} & 1,50 & 0,92 & 1,24 & 1,89 & 5,05 & 72,83 \\ \text { Met } & 0,46 & 0,46 & 1,22 & 1,53 & 5,00 & 77,82 \\ \text { Op } & 2,52 & 1,92 & 1,22 & 1,69 & 4,97 & 82,80 \\ \text { Hom } & 1,16 & 0,92 & 1,14 & 0,93 & 4,66 & 87,45 \\ \text { Mig } & 3,27 & 3,80 & 1,05 & 1,72 & 4,28 & 91,74\end{array}$


Groups 3 \& 4

Average dissimilarity $=23,51$

$$
\text { Group } 3 \text { Group } 4
$$

$\begin{array}{lrrrrrl}\text { Species } & \text { Av.Abund } & \text { Av.Abund } & \text { Av.Diss } & \text { Diss/SD } & \text { Contrib\% } & \text { Cum.\% } \\ \mathrm{Eu} & 3,89 & 2,33 & 2,69 & 6,61 & 11,45 & 11,45 \\ \mathrm{Ag} & 1,42 & 1,07 & 2,50 & 1,41 & 10,63 & 22,08 \\ \mathrm{Al} & 4,17 & 3,16 & 2,21 & 1,51 & 9,38 & 31,46 \\ \mathrm{Op} & 3,08 & 1,92 & 2,04 & 2,96 & 8,67 & 40,13 \\ \mathrm{Aph} & 4,12 & 3,17 & 2,01 & 1,35 & 8,55 & 48,69 \\ \mathrm{He} & 1,76 & 0,92 & 1,54 & 1,44 & 6,56 & 55,24 \\ \mathrm{Ro} & 1,93 & 1,36 & 1,44 & 1,44 & 6,14 & 61,38 \\ \mathrm{Do} & 0,88 & 1,06 & 1,35 & 1,69 & 5,76 & 67,14 \\ \mathrm{Hom} & 0,46 & 0,92 & 1,31 & 1,04 & 5,56 & 72,71 \\ \mathrm{Ch} & 1,94 & 2,69 & 1,28 & 1,49 & 5,46 & 78,16 \\ \mathrm{Br} & 2,76 & 2,39 & 1,24 & 1,08 & 5,29 & 83,45 \\ \text { Mac } & 0,60 & 0,00 & 1,08 & 1,21 & 4,58 & 88,02 \\ \text { Hor } & 0,23 & 0,83 & 1,03 & 1,51 & 4,39 & 92,42\end{array}$

Groups $1 \& 5$

Average dissimilarity $=39,18$

$\begin{array}{lrrrrrl} & \text { Group 1 } & \text { Group 5 } & & & & \\ \text { Species } & \text { Av.Abund } & \text { Av.Abund } & \text { Av.Diss } & \text { Diss/SD } & \text { Contrib\% } & \text { Cum.\% } \\ \text { Eu } & 3,04 & 0,69 & 5,67 & 1,87 & 14,48 & 14,48 \\ \text { Ro } & 0,23 & 2,12 & 4,48 & 3,55 & 11,44 & 25,92 \\ \text { Ch } & 0,23 & 2,06 & 4,32 & 2,23 & 11,03 & 36,95 \\ \text { Br } & 0,96 & 2,38 & 3,34 & 5,39 & 8,53 & 45,48 \\ \text { Al } & 3,40 & 2,48 & 2,97 & 1,36 & 7,57 & 53,05 \\ \text { Mig } & 2,77 & 3,95 & 2,85 & 2,31 & 7,27 & 60,32 \\ \text { Op } & 1,13 & 1,70 & 2,15 & 1,14 & 5,50 & 65,82 \\ \text { Ag } & 0,46 & 0,96 & 2,12 & 1,20 & 5,40 & 71,22 \\ \text { Aph } & 2,92 & 2,50 & 1,98 & 1,44 & 5,05 & 76,27 \\ \text { Hom } & 0,77 & 0,46 & 1,86 & 1,15 & 4,75 & 81,02 \\ \text { Mac } & 1,06 & 0,69 & 1,41 & 1,21 & 3,61 & 84,63 \\ \text { Mir } & 0,60 & 0,00 & 1,41 & 1,27 & 3,60 & 88,24 \\ \text { He } & 1,39 & 1,66 & 1,33 & 1,26 & 3,40 & 91,64\end{array}$

Groups 2 \& 5

Average dissimilarity $=31,16$

Group 2 Group 5

$\begin{array}{lrrrrrr}\text { Species } & \text { Av.Abund } & \text { Av.Abund } & \text { Av.Diss } & \text { Diss/SD } & \text { Contrib\% } & \text { Cum.\% } \\ \text { Eu } & 3,31 & 0,69 & 5,60 & 2,00 & 17,98 & 17,98 \\ \text { Al } & 3,75 & 2,48 & 3,12 & 1,29 & 10,01 & 27,98\end{array}$




$\begin{array}{lllllll}\text { Ch } & 0,77 & 2,06 & 2,98 & 1,60 & 9,57 & 37,55 \\ \text { Ro } & 0,90 & 2,12 & 2,64 & 1,39 & 8,48 & 46,03 \\ \text { Aph } & 3,59 & 2,50 & 2,52 & 1,24 & 8,09 & 54,12 \\ \text { Hom } & 1,16 & 0,46 & 1,81 & 1,50 & 5,81 & 59,93 \\ \text { Ag } & 0,37 & 0,96 & 1,81 & 1,15 & 5,80 & 65,73 \\ \text { Op } & 2,52 & 1,70 & 1,77 & 1,45 & 5,68 & 71,40 \\ \text { Mig } & 3,27 & 3,95 & 1,50 & 1,41 & 4,83 & 76,23 \\ \text { Do } & 0,69 & 0,46 & 1,46 & 16,30 & 4,69 & 80,92 \\ \text { Br } & 1,75 & 2,38 & 1,35 & 1,11 & 4,34 & 85,26 \\ \text { Met } & 0,46 & 0,23 & 1,13 & 0,94 & 3,61 & 88,87 \\ \text { Mac } & 0,46 & 0,69 & 1,12 & 1,15 & 3,60 & 92,48\end{array}$

Groups $3 \& 5$

Average dissimilarity $=27,68$

$\begin{array}{lrrrrrl}\text { Species } & \text { Group 3 } & \text { Group 5 } & & & & \\ \text { Eu } & \text { Av.Abund } & \text { Av.Abund } & \text { Av.Diss } & \text { Diss/SD } & \text { Contrib\% } & \text { Cum.\% } \\ \text { Al } & 3,89 & 0,69 & 5,93 & 2,83 & 21,42 & 21,42 \\ \text { Aph } & 4,17 & 2,48 & 3,26 & 1,43 & 11,77 & 33,19 \\ \text { Ag } & 4,12 & 2,50 & 2,96 & 1,66 & 10,70 & 43,88 \\ \text { Op } & 1,42 & 0,96 & 2,57 & 1,39 & 9,30 & 53,18 \\ \text { Do } & 3,08 & 1,70 & 2,53 & 2,22 & 9,13 & 62,31 \\ \text { Ch } & 0,88 & 0,46 & 1,61 & 1,19 & 5,82 & 68,13 \\ \text { Hom } & 1,94 & 2,06 & 1,25 & 2,03 & 4,51 & 72,64 \\ \text { He } & 0,46 & 0,46 & 1,14 & 0,84 & 4,13 & 76,77 \\ \text { Mac } & 1,76 & 1,66 & 1,10 & 1,43 & 3,97 & 80,75 \\ \text { Ro } & 0,60 & 0,69 & 1,07 & 1,28 & 3,85 & 84,60 \\ \text { Mig } & 1,93 & 2,12 & 0,87 & 1,15 & 3,14 & 87,74 \\ & 3,91 & 3,95 & 0,87 & 1,50 & 3,14 & 90,87\end{array}$

Groups 4 \& 5

Average dissimilarity $=24,67$

$\begin{array}{lrrrrrr} & \text { Group 4 } & \text { Group 5 } & & & & \\ \text { Species } & \text { Av.Abund } & \text { Av.Abund } & \text { Av.Diss } & \text { Diss/SD } & \text { Contrib\% } & \text { Cum.\% } \\ \text { Eu } & 2,33 & 0,69 & 3,46 & 1,52 & 14,01 & 14,01 \\ \text { Al } & 3,16 & 2,48 & 2,88 & 1,45 & 11,66 & 25,67 \\ \text { Ro } & 1,36 & 2,12 & 2,00 & 1,43 & 8,09 & 33,76 \\ \text { Aph } & 3,17 & 2,50 & 1,83 & 1,31 & 7,40 & 41,16 \\ \text { Ch } & 2,69 & 2,06 & 1,76 & 1,28 & 7,15 & 48,31 \\ \text { Ag } & 1,07 & 0,96 & 1,72 & 1,16 & 6,99 & 55,30 \\ \text { Do } & 1,06 & 0,46 & 1,65 & 1,87 & 6,68 & 61,98 \\ \text { Hom } & 0,92 & 0,46 & 1,56 & 1,05 & 6,32 & 68,30 \\ \text { He } & 0,92 & 1,66 & 1,43 & 1,44 & 5,78 & 74,07\end{array}$




$\begin{array}{lllllll}\mathrm{Br} & 2,39 & 2,38 & 1,42 & 1,60 & 5,75 & 79,82 \\ \mathrm{Mac} & 0,00 & 0,69 & 1,40 & 1,18 & 5,66 & 85,48 \\ \mathrm{Op} & 1,92 & 1,70 & 1,11 & 1,54 & 4,49 & 89,97 \\ \text { Mig } & 3,80 & 3,95 & 0,93 & 1,17 & 3,78 & 93,75\end{array}$

Groups $1 \& 6$

Average dissimilarity $=42,03$

$\begin{array}{lrrrrrl} & \text { Group 1 } & \text { Group 6 } & & & & \\ \text { Species } & \text { Av.Abund } & \text { Av.Abund } & \text { Av.Diss } & \text { Diss/SD } & \text { Contrib\% } & \text { Cum.\% } \\ \text { Eu } & 3,04 & 1,03 & 5,43 & 1,78 & 12,93 & 12,93 \\ \text { Ro } & 0,23 & 1,93 & 4,31 & 4,68 & 10,25 & 23,18 \\ \text { Aph } & 2,92 & 1,29 & 4,10 & 2,29 & 9,76 & 32,93 \\ \text { Br } & 0,96 & 2,52 & 3,99 & 3,15 & 9,50 & 42,43 \\ \text { Al } & 3,40 & 2,15 & 3,91 & 1,62 & 9,31 & 51,74 \\ \text { Ch } & 0,23 & 1,57 & 3,51 & 1,73 & 8,35 & 60,10 \\ \text { Mig } & 2,77 & 3,97 & 3,05 & 13,80 & 7,26 & 67,36 \\ \text { Ag } & 0,46 & 0,92 & 2,30 & 1,20 & 5,47 & 72,82 \\ \text { Mac } & 1,06 & 0,23 & 2,12 & 1,77 & 5,04 & 77,86 \\ \text { Op } & 1,13 & 1,13 & 1,97 & 1,47 & 4,68 & 82,54 \\ \text { Hom } & 0,77 & 1,29 & 1,96 & 1,32 & 4,67 & 87,20 \\ \text { Mir } & 0,60 & 0,00 & 1,52 & 1,27 & 3,61 & 90,81\end{array}$

Groups $2 \& 6$

Average dissimilarity $=33,85$

$$
\text { Group } 2 \text { Group } 6
$$

Species Av.Abund Av.Abund

Aph

3,59

1,29

Av.Diss

Diss/SD

Contrib\%

Cum.\%

$\mathrm{Eu}$

3,31

1,03

5,24

2,52

$15,50 \quad 15,50$

Al

3,75

2,15

5,23

1,70

$15,45 \quad 30,95$

Op

2,52

4,02

1,46

$11,87 \quad 42,82$

Ro

0,90

1,13

3,12

2,95

$9,21 \quad 52,03$

$\mathrm{Ch}$

0,77

1,93

2,37

1,31

$7,01 \quad 59,04$

Ag

0,37

1,57

2,34

1,32

$6,92 \quad 65,96$

$\mathrm{Br}$

1,75

0,92

1,95

1,17

$5,76 \quad 71,72$

Mig

2,52

1,79

1,12

$5,30 \quad 77,02$

$\mathrm{He}$

3,27

3,97

1,57

3,40

$4,64 \quad 81,65$

Hom

1,50

1,29

1,03

1,35

$3,04 \quad 84,69$

Met

1,16

1,29

1,02

1,09

3,03

87,72

1,01

0,67

3,00

90,72 
Groups 3 \& 6

Average dissimilarity $=32,36$

$$
\text { Group } 3 \text { Group } 6
$$

$\begin{array}{lrrrrrr}\text { Species } & \text { Av.Abund } & \text { Av.Abund } & \text { Av.Diss } & \text { Diss/SD } & \text { Contrib\% } & \text { Cum.\% } \\ \text { Eu } & 3,89 & 1,03 & 5,62 & 2,44 & 17,37 & 17,37 \\ \text { Aph } & 4,12 & 1,29 & 5,44 & 3,75 & 16,81 & 34,18 \\ \text { Al } & 4,17 & 2,15 & 4,10 & 1,63 & 12,66 & 46,84 \\ \text { Op } & 3,08 & 1,13 & 3,79 & 4,05 & 11,70 & 58,54 \\ \text { Ag } & 1,42 & 0,92 & 2,68 & 1,16 & 8,27 & 66,81 \\ \text { Hom } & 0,46 & 1,29 & 1,89 & 1,57 & 5,83 & 72,64 \\ \text { Do } & 0,88 & 0,23 & 1,54 & 1,05 & 4,76 & 77,40 \\ \mathrm{He} & 1,76 & 1,29 & 1,39 & 1,36 & 4,30 & 81,70 \\ \mathrm{Mac} & 0,60 & 0,23 & 1,03 & 1,16 & 3,19 & 84,89 \\ \mathrm{Ch} & 1,94 & 1,57 & 0,93 & 0,89 & 2,86 & 87,75 \\ \mathrm{Br} & 2,76 & 2,52 & 0,89 & 1,42 & 2,75 & 90,51\end{array}$

Groups 4 \& 6

Average dissimilarity $=28,20$

$\begin{array}{lrrrrrl} & \text { Group 4 } & \text { Group 6 } & & & & \\ \text { Species } & \text { Av.Abund } & \text { Av.Abund } & \text { Av.Diss } & \text { Diss/SD } & \text { Contrib\% } & \text { Cum.\% } \\ \text { Aph } & 3,17 & 1,29 & 4,06 & 2,84 & 14,38 & 14,38 \\ \text { Al } & 3,16 & 2,15 & 3,43 & 1,50 & 12,16 & 26,54 \\ \text { Eu } & 2,33 & 1,03 & 3,04 & 1,28 & 10,80 & 37,34 \\ \text { Ch } & 2,69 & 1,57 & 2,34 & 1,43 & 8,30 & 45,64 \\ \text { Ag } & 1,07 & 0,92 & 2,12 & 1,39 & 7,52 & 53,15 \\ \text { Ro } & 1,36 & 1,93 & 1,84 & 1,69 & 6,53 & 59,68 \\ \text { Do } & 1,06 & 0,23 & 1,74 & 1,94 & 6,17 & 65,85 \\ \text { Op } & 1,92 & 1,13 & 1,69 & 1,64 & 6,00 & 71,84 \\ \text { Br } & 2,39 & 2,52 & 1,64 & 1,33 & 5,80 & 77,64 \\ \text { Hom } & 0,92 & 1,29 & 1,58 & 1,05 & 5,59 & 83,23 \\ \text { Hor } & 0,83 & 0,37 & 1,42 & 1,91 & 5,05 & 88,28 \\ \text { He } & 0,92 & 1,29 & 1,13 & 1,21 & 3,99 & 92,27\end{array}$

Groups $5 \& 6$

Average dissimilarity $=25,19$

$\begin{array}{lrrrrrl} & \text { Group 5 } & \text { Group 6 } & & & & \\ \text { Species } & \text { Av.Abund } & \text { Av.Abund } & \text { Av.Diss } & \text { Diss/SD } & \text { Contrib\% } & \text { Cum.\% } \\ \text { Al } & 2,48 & 2,15 & 3,09 & 1,22 & 12,26 & 12,26 \\ \text { Aph } & 2,50 & 1,29 & 2,84 & 1,84 & 11,26 & 23,52 \\ \text { Eu } & 0,69 & 1,03 & 2,54 & 1,13 & 10,07 & 33,59 \\ \text { Hom } & 0,46 & 1,29 & 2,37 & 1,49 & 9,40 & 42,99 \\ \text { Ag } & 0,96 & 0,92 & 2,20 & 1,40 & 8,72 & 51,71\end{array}$




$\begin{array}{lllllll}\text { Ch } & 2,06 & 1,57 & 2,04 & 1,49 & 8,11 & 59,81 \\ \text { Op } & 1,70 & 1,13 & 1,62 & 1,18 & 6,44 & 66,25 \\ \text { Mac } & 0,69 & 0,23 & 1,40 & 1,19 & 5,57 & 71,82 \\ \text { Do } & 0,46 & 0,23 & 1,31 & 0,94 & 5,19 & 77,01 \\ \text { He } & 1,66 & 1,29 & 1,23 & 1,26 & 4,87 & 81,88 \\ \text { Hor } & 0,46 & 0,37 & 1,21 & 1,45 & 4,81 & 86,69 \\ \text { Ro } & 2,12 & 1,93 & 0,97 & 1,48 & 3,86 & 90,55\end{array}$

Groups $1 \& 7$

Average dissimilarity $=47,50$

$$
\text { Group } 1 \quad \text { Group } 7
$$

Species Av.Abund Av.Abund

Aph

2,92

$$
0,77
$$

Av.Diss

Diss/SD

Contrib\%

Cum.\%

$\mathrm{Eu}$

3,04

1,06

5,74

2,02

$12,08 \quad 12,08$

Al

3,40

1,82

5,25

2,21

11,05

23,13

Mig

2,77

4,97

1,53

10,46

33,59

$\mathrm{Br}$

0,96

4,14

3,68

5,65

7,75

41,35

Ro

0,23

2,22

3,33

1,84

7,02

48,37

Hom

0,77

1,52

3,27

1,95

$6,88 \quad 55,25$

$\mathrm{He}$

1,39

1,62

2,88

1,22

6,06

61,30

Op

1,13

0,46

2,56

1,28

5,40

66,70

2,55

1,28

$5,36 \quad 72,06$

Ag

0,46

2,54

1,26

$5,34 \quad 77,40$

$\mathrm{Ch}$

0,23

2,53

1,76

$5,33 \quad 82,74$

Mac

1,06

2,20

4,63

87,37

Hor

0,00

0,46

1,58

3,88

91,25

Groups 2 \& 7

Average dissimilarity $=40,51$

$$
\text { Group } 2 \text { Group } 7
$$

$\begin{array}{lrrrrrl}\text { Species } & \text { Av.Abund } & \text { Av.Abund } & \text { Av.Diss } & \text { Diss/SD } & \text { Contrib\% } & \text { Cum.\% } \\ \text { Aph } & 3,59 & 0,77 & 6,71 & 2,25 & 16,57 & 16,57 \\ \mathrm{Eu} & 3,31 & 1,06 & 5,30 & 2,62 & 13,09 & 29,66 \\ \mathrm{Al} & 3,75 & 1,82 & 4,96 & 1,43 & 12,24 & 41,89 \\ \mathrm{Op} & 2,52 & 0,88 & 3,95 & 1,71 & 9,74 & 51,63 \\ \mathrm{He} & 1,50 & 0,46 & 2,49 & 1,93 & 6,14 & 57,77 \\ \mathrm{Ag} & 0,37 & 1,06 & 2,14 & 1,18 & 5,28 & 63,05 \\ \mathrm{Ro} & 0,90 & 1,52 & 2,14 & 1,43 & 5,27 & 68,32 \\ \mathrm{Mig} & 3,27 & 4,14 & 2,06 & 3,15 & 5,09 & 73,41 \\ \mathrm{Hom} & 1,16 & 1,62 & 1,89 & 1,18 & 4,68 & 78,09 \\ \mathrm{Br} & 1,75 & 2,22 & 1,72 & 1,21 & 4,24 & 82,33 \\ \mathrm{Ch} & 0,77 & 1,16 & 1,66 & 1,30 & 4,11 & 86,44 \\ \mathrm{Hor} & 0,00 & 0,73 & 1,62 & 1,33 & 4,01 & 90,44\end{array}$


Groups 3 \& 7

Average dissimilarity $=40,29$

$$
\text { Group } 3 \text { Group } 7
$$

$\begin{array}{lrrrrrl}\text { Species } & \text { Av.Abund } & \text { Av.Abund } & \text { Av.Diss } & \text { Diss/SD } & \text { Contrib\% } & \text { Cum.\% } \\ \text { Aph } & 4,12 & 0,77 & 6,70 & 3,04 & 16,62 & 16,62 \\ \text { Eu } & 3,89 & 1,06 & 5,70 & 5,43 & 14,14 & 30,77 \\ \mathrm{Al} & 4,17 & 1,82 & 4,92 & 1,59 & 12,21 & 42,97 \\ \mathrm{Op} & 3,08 & 0,88 & 4,50 & 2,22 & 11,18 & 54,15 \\ \mathrm{Ag} & 1,42 & 1,06 & 2,85 & 1,38 & 7,07 & 61,23 \\ \mathrm{Hom} & 0,46 & 1,62 & 2,66 & 1,50 & 6,60 & 67,83 \\ \mathrm{He} & 1,76 & 0,46 & 2,66 & 1,68 & 6,60 & 74,42 \\ \mathrm{Do} & 0,88 & 0,60 & 1,56 & 1,26 & 3,87 & 78,30 \\ \mathrm{Br} & 2,76 & 2,22 & 1,54 & 1,67 & 3,81 & 82,11 \\ \mathrm{Ch} & 1,94 & 1,16 & 1,53 & 2,49 & 3,80 & 85,90 \\ \mathrm{Ro} & 1,93 & 1,52 & 1,35 & 1,20 & 3,35 & 89,26 \\ \mathrm{Mac} & 0,60 & 0,46 & 1,34 & 1,35 & 3,33 & 92,59\end{array}$

Groups 4 \& 7

Average dissimilarity $=33,29$

$$
\text { Group } 4 \text { Group } 7
$$

$\begin{array}{lrrrrrl}\text { Species } & \text { Av.Abund } & \text { Av.Abund } & \text { Av.Diss } & \text { Diss/SD } & \text { Contrib\% } & \text { Cum.\% } \\ \text { Aph } & 3,17 & 0,77 & 5,44 & 2,33 & 16,33 & 16,33 \\ \mathrm{Al} & 3,16 & 1,82 & 4,28 & 1,56 & 12,86 & 29,18 \\ \mathrm{Ch} & 2,69 & 1,16 & 3,38 & 3,05 & 10,15 & 39,34 \\ \mathrm{Eu} & 2,33 & 1,06 & 2,95 & 2,84 & 8,85 & 48,19 \\ \mathrm{Op} & 1,92 & 0,88 & 2,62 & 1,38 & 7,86 & 56,05 \\ \mathrm{Hom} & 0,92 & 1,62 & 2,45 & 1,16 & 7,35 & 63,40 \\ \mathrm{Ag} & 1,07 & 1,06 & 2,10 & 1,31 & 6,32 & 69,71 \\ \mathrm{Br} & 2,39 & 2,22 & 1,87 & 1,42 & 5,61 & 75,32 \\ \mathrm{Ro} & 1,36 & 1,52 & 1,73 & 1,35 & 5,19 & 80,51 \\ \mathrm{Do} & 1,06 & 0,60 & 1,21 & 1,23 & 3,65 & 84,16 \\ \mathrm{He} & 0,92 & 0,46 & 1,17 & 0,88 & 3,51 & 87,66 \\ \text { Hor } & 0,83 & 0,73 & 1,08 & 1,29 & 3,25 & 90,91\end{array}$

Groups 5 \& 7

Average dissimilarity $=33,81$

$$
\text { Group } 5 \text { Group } 7
$$

$\begin{array}{lrrrrrr}\text { Species } & \text { Av.Abund } & \text { Av.Abund } & \text { Av.Diss } & \text { Diss/SD } & \text { Contrib\% } & \text { Cum.\% } \\ \text { Aph } & 2,50 & 0,77 & 4,28 & 1,70 & 12,65 & 12,65 \\ \text { Al } & 2,48 & 1,82 & 3,68 & 1,22 & 10,89 & 23,55 \\ \text { Hom } & 0,46 & 1,62 & 3,34 & 1,39 & 9,88 & 33,43 \\ \text { He } & 1,66 & 0,46 & 2,93 & 2,12 & 8,68 & 42,10\end{array}$




$\begin{array}{lllllll}\mathrm{Op} & 1,70 & 0,88 & 2,74 & 1,42 & 8,10 & 50,21 \\ \mathrm{Eu} & 0,69 & 1,06 & 2,53 & 3,68 & 7,49 & 57,70 \\ \mathrm{Ch} & 2,06 & 1,16 & 2,45 & 1,69 & 7,23 & 64,93 \\ \mathrm{Ag} & 0,96 & 1,06 & 2,12 & 1,27 & 6,27 & 71,20 \\ \mathrm{Ro} & 2,12 & 1,52 & 1,92 & 1,15 & 5,69 & 76,89 \\ \mathrm{Mac} & 0,69 & 0,46 & 1,68 & 1,18 & 4,96 & 81,85 \\ \mathrm{Do} & 0,46 & 0,60 & 1,63 & 1,30 & 4,83 & 86,68 \\ \mathrm{Br} & 2,38 & 2,22 & 1,52 & 2,47 & 4,51 & 91,19\end{array}$

Groups 6 \& 7

Average dissimilarity $=27,04$

$$
\text { Group } 6 \quad \text { Group } 7
$$

Species Av.Abund Av.Abun

$\begin{array}{lrlllrl}\mathrm{Al} & 2,15 & 1,82 & 3,49 & 1,14 & 12,91 & 12,91 \\ \mathrm{Ag} & 0,92 & 1,06 & 2,52 & 1,30 & 9,31 & 22,22 \\ \mathrm{Eu} & 1,03 & 1,06 & 2,38 & 1,72 & 8,79 & 31,01 \\ \mathrm{He} & 1,29 & 0,46 & 2,29 & 1,31 & 8,46 & 39,47 \\ \mathrm{Op} & 1,13 & 0,88 & 2,12 & 1,49 & 7,84 & 47,31 \\ \mathrm{Hom} & 1,29 & 1,62 & 2,10 & 1,23 & 7,78 & 55,09 \\ \mathrm{Aph} & 1,29 & 0,77 & 2,00 & 1,45 & 7,40 & 62,49 \\ \mathrm{Ch} & 1,57 & 1,16 & 1,90 & 1,98 & 7,04 & 69,53 \\ \mathrm{Br} & 2,52 & 2,22 & 1,78 & 1,46 & 6,60 & 76,13 \\ \mathrm{Hor} & 0,37 & 0,73 & 1,58 & 1,05 & 5,84 & 81,97 \\ \text { Ro } & 1,93 & 1,52 & 1,50 & 0,91 & 5,56 & 87,53 \\ \text { Mac } & 0,23 & 0,46 & 1,42 & 0,96 & 5,24 & 92,77\end{array}$

Groups 1 \& 8

Average dissimilarity $=48,78$

$$
\text { Group } 1 \text { Group } 8
$$

$\begin{array}{lrrrrrl}\text { Species } & \text { Av.Abund } & \text { Av.Abund } & \text { Av.Diss } & \text { Diss/SD } & \text { Contrib\% } & \text { Cum.\% } \\ \text { Eu } & 3,04 & 0,23 & 6,92 & 3,05 & 14,19 & 14,19 \\ \text { Ch } & 0,23 & 2,34 & 5,27 & 2,01 & 10,81 & 25,00 \\ \text { Ro } & 0,23 & 2,11 & 4,64 & 4,31 & 9,52 & 34,52 \\ \text { Aph } & 2,92 & 1,32 & 4,34 & 1,35 & 8,90 & 43,42 \\ \text { Mig } & 2,77 & 4,30 & 3,73 & 4,31 & 7,64 & 51,06 \\ \text { Hom } & 0,77 & 2,21 & 3,59 & 1,67 & 7,36 & 58,42 \\ \mathrm{Br} & 0,96 & 2,04 & 3,07 & 1,60 & 6,30 & 64,72 \\ \mathrm{Al} & 3,40 & 2,65 & 2,85 & 1,30 & 5,83 & 70,56 \\ \mathrm{Ag} & 0,46 & 1,43 & 2,75 & 1,57 & 5,64 & 76,20 \\ \mathrm{Op} & 1,13 & 0,60 & 2,31 & 1,53 & 4,74 & 80,95 \\ \mathrm{Mac} & 1,06 & 0,23 & 2,14 & 1,63 & 4,38 & 85,33 \\ \mathrm{He} & 1,39 & 0,90 & 2,13 & 1,22 & 4,38 & 89,70\end{array}$




$\begin{array}{llllll}\text { Hor } & 0,00 & 0,69 & 1,62 & 1,12 & 3,33\end{array}$

Groups $2 \& 8$

Average dissimilarity $=42,75$ Group 2 Group 8

$\begin{array}{lrrrrrr}\text { Species } & \text { Av.Abund } & \text { Av.Abund } & \text { Av.Diss } & \text { Diss/SD } & \text { Contrib\% } & \text { Cum.\% } \\ \text { Eu } & 3,31 & 0,23 & 6,76 & 3,35 & 15,82 & 15,82 \\ \text { Aph } & 3,59 & 1,32 & 5,16 & 1,47 & 12,06 & 27,88 \\ \text { Op } & 2,52 & 0,60 & 4,27 & 2,85 & 9,98 & 37,86 \\ \text { Ch } & 0,77 & 2,34 & 3,76 & 1,62 & 8,78 & 46,64 \\ \text { Al } & 3,75 & 2,65 & 3,00 & 1,23 & 7,02 & 53,66 \\ \text { Ro } & 0,90 & 2,11 & 2,72 & 1,50 & 6,36 & 60,02 \\ \mathrm{Ag} & 0,37 & 1,43 & 2,48 & 1,66 & 5,80 & 65,82 \\ \mathrm{Hom} & 1,16 & 2,21 & 2,41 & 1,61 & 5,63 & 71,44 \\ \mathrm{Mig} & 3,27 & 4,30 & 2,21 & 2,41 & 5,17 & 76,61 \\ \mathrm{Br} & 1,75 & 2,04 & 2,13 & 1,65 & 4,98 & 81,60 \\ \mathrm{He} & 1,50 & 0,90 & 1,65 & 1,00 & 3,85 & 85,45 \\ \mathrm{Do} & 0,69 & 0,00 & 1,51 & 9,81 & 3,54 & 88,99 \\ \text { Hor } & 0,00 & 0,69 & 1,44 & 1,13 & 3,37 & 92,36\end{array}$

Groups $3 \& 8$

Average dissimilarity $=38,90$

$\begin{array}{lrrrrrr}\text { Gpecies } & \text { Group 3 } & \text { Group } 8 & & & & \\ \text { Eu } & \text { Av.Abund } & \text { Av.Abund } & \text { Av.Diss } & \text { Diss/SD } & \text { Contrib\% } & \text { Cum.\% } \\ \text { Aph } & 3,89 & 0,23 & 6,95 & 6,18 & 17,87 & 17,87 \\ \text { Op } & 4,12 & 1,32 & 5,34 & 1,88 & 13,73 & 31,60 \\ \text { Hom } & 3,08 & 0,60 & 4,76 & 3,55 & 12,22 & 43,82 \\ \text { Al } & 0,46 & 2,21 & 3,32 & 2,05 & 8,53 & 52,35 \\ \text { Ag } & 4,17 & 2,65 & 3,14 & 1,36 & 8,06 & 60,41 \\ \mathrm{He} & 1,42 & 1,43 & 2,64 & 1,58 & 6,78 & 67,19 \\ \text { Ch } & 1,76 & 0,90 & 1,91 & 1,10 & 4,91 & 72,10 \\ \text { Br } & 1,94 & 2,34 & 1,83 & 5,02 & 4,71 & 76,80 \\ \text { Do } & 2,76 & 2,04 & 1,82 & 1,11 & 4,69 & 81,49 \\ \text { Hor } & 0,88 & 0,00 & 1,63 & 1,01 & 4,20 & 85,70 \\ \text { Mig } & 0,23 & 0,69 & 1,14 & 1,13 & 2,94 & 88,64 \\ & 3,91 & 4,30 & 1,03 & 1,50 & 2,64 & 91,28\end{array}$


Groups 4 \& 8

Average dissimilarity $=33,35$

$$
\text { Group } 4 \text { Group } 8
$$

$\begin{array}{lrrrrrr}\text { Species } & \text { Av.Abund } & \text { Av.Abund } & \text { Av.Diss } & \text { Diss/SD } & \text { Contrib\% } & \text { Cum.\% } \\ \text { Eu } & 2,33 & 0,23 & 4,52 & 3,82 & 13,56 & 13,56 \\ \text { Aph } & 3,17 & 1,32 & 4,04 & 1,36 & 12,13 & 25,68 \\ \text { Hom } & 0,92 & 2,21 & 2,92 & 1,33 & 8,77 & 34,45 \\ \text { Op } & 1,92 & 0,60 & 2,85 & 2,13 & 8,55 & 43,00 \\ \text { Al } & 3,16 & 2,65 & 2,77 & 1,37 & 8,31 & 51,30 \\ \text { Br } & 2,39 & 2,04 & 2,21 & 1,37 & 6,63 & 57,93 \\ \text { Do } & 1,06 & 0,00 & 2,21 & 4,28 & 6,62 & 64,55 \\ \text { Ro } & 1,36 & 2,11 & 1,94 & 1,37 & 5,82 & 70,36 \\ \text { Ag } & 1,07 & 1,43 & 1,90 & 1,31 & 5,69 & 76,06 \\ \text { Ch } & 2,69 & 2,34 & 1,87 & 1,58 & 5,61 & 81,67 \\ \text { He } & 0,92 & 0,90 & 1,44 & 1,45 & 4,33 & 85,99 \\ \text { Mig } & 3,80 & 4,30 & 1,16 & 1,14 & 3,49 & 89,48 \\ \text { Hor } & 0,83 & 0,69 & 1,12 & 1,33 & 3,36 & 92,84\end{array}$

Groups $5 \& 8$

Average dissimilarity $=29,88$

$\begin{array}{lrrrrrl} & \text { Group 5 } & \text { Group } 8 & & & & \\ \text { Species } & \text { Av.Abund } & \text { Av.Abund } & \text { Av.Diss } & \text { Diss/SD } & \text { Contrib\% } & \text { Cum.\% } \\ \text { Hom } & 0,46 & 2,21 & 4,12 & 1,86 & 13,79 & 13,79 \\ \text { Aph } & 2,50 & 1,32 & 3,26 & 1,22 & 10,91 & 24,70 \\ \mathrm{Al} & 2,48 & 2,65 & 2,84 & 1,20 & 9,51 & 34,21 \\ \mathrm{Op} & 1,70 & 0,60 & 2,60 & 1,37 & 8,70 & 42,90 \\ \mathrm{Ch} & 2,06 & 2,34 & 2,11 & 1,18 & 7,05 & 49,95 \\ \mathrm{He} & 1,66 & 0,90 & 2,02 & 1,14 & 6,75 & 56,71 \\ \mathrm{Ag} & 0,96 & 1,43 & 1,98 & 1,52 & 6,62 & 63,33 \\ \mathrm{Br} & 2,38 & 2,04 & 1,95 & 1,35 & 6,53 & 69,86 \\ \mathrm{Eu} & 0,69 & 0,23 & 1,66 & 0,85 & 5,57 & 75,43 \\ \mathrm{Mac} & 0,69 & 0,23 & 1,39 & 1,13 & 4,64 & 80,07 \\ \mathrm{Mig} & 3,95 & 4,30 & 1,25 & 1,51 & 4,17 & 84,23 \\ \text { Hor } & 0,46 & 0,69 & 1,23 & 1,17 & 4,13 & 88,37 \\ \text { Do } & 0,46 & 0,00 & 1,10 & 0,66 & 3,67 & 92,04\end{array}$

Groups 6 \& 8

Average dissimilarity $=26,41$

Group $6 \quad$ Group 8

$\begin{array}{lrrrrrl}\text { Species } & \text { Av.Abund } & \text { Av.Abund } & \text { Av.Diss } & \text { Diss/SD } & \text { Contrib\% } & \text { Cum.\% } \\ \mathrm{Al} & 2,15 & 2,65 & 3,17 & 1,27 & 11,99 & 11,99 \\ \mathrm{Ch} & 1,57 & 2,34 & 2,84 & 1,92 & 10,75 & 22,74\end{array}$




$\begin{array}{lllllll}\mathrm{Ag} & 0,92 & 1,43 & 2,34 & 1,33 & 8,88 & 31,62 \\ \mathrm{Hom} & 1,29 & 2,21 & 2,32 & 1,31 & 8,77 & 40,39 \\ \mathrm{Aph} & 1,29 & 1,32 & 2,26 & 1,42 & 8,56 & 48,96 \\ \mathrm{Eu} & 1,03 & 0,23 & 2,24 & 0,97 & 8,49 & 57,45 \\ \mathrm{Br} & 2,52 & 2,04 & 2,23 & 1,19 & 8,44 & 65,89 \\ \mathrm{He} & 1,29 & 0,90 & 1,87 & 1,16 & 7,10 & 72,99 \\ \mathrm{Op} & 1,13 & 0,60 & 1,60 & 1,12 & 6,08 & 79,06 \\ \mathrm{Hor} & 0,37 & 0,69 & 1,58 & 1,17 & 5,97 & 85,03 \\ \mathrm{Ne} & 0,00 & 0,46 & 1,05 & 1,33 & 3,99 & 89,03 \\ \mathrm{Mig} & 3,97 & 4,30 & 0,89 & 1,04 & 3,37 & 92,40\end{array}$

Groups $7 \& 8$

Average dissimilarity $=31,20$

$$
\text { Group } 7 \text { Group } 8
$$

Species Av.Abund Av.Abund Av.Diss

Al

$$
1,82
$$

2,65

3,95

Diss/SD

Contrib\% Cum.\%

1,40

$12,65 \quad 12,65$

$\mathrm{Ch}$

1,16

2,34

3,33

1,68

$10,68 \quad 23,32$

Aph

0,77

1,32

2,80

1,27

$8,98 \quad 32,31$

$\mathrm{Br}$

2,22

2,04

2,52

1,57

$8,08 \quad 40,39$

Ag

1,06

1,43

2,30

1,44

$7,37 \quad 47,76$

Hom

1,62

2,21

2,23

1,31

$7,13 \quad 54,89$

$\mathrm{Eu}$

1,06

0,23

2,10

1,81

6,74

61,63

Op

0,88

0,60

1,90

1,22

6,09

67,72

$\mathrm{He}$

0,46

0,90

1,88

1,49

6,02

73,74

Ro

1,52

2,11

0,93

$5,49 \quad 79,23$

Hor

0,73

0,69

1,71

1,23

5,18

84,41

Do

0,60

0,00

1,15

5,02

89,42

Mac

0,46

0,23

0,89

4,28

93,70

Groups $1 \& 9$

Average dissimilarity $=46,49$

$\begin{array}{lrrrrrl} & \text { Group 1 } & \text { Group 9 } & & & & \\ \text { Species } & \text { Av.Abund } & \text { Av.Abund } & \text { Av.Diss } & \text { Diss/SD } & \text { Contrib\% } & \text { Cum.\% } \\ \text { Ch } & 0,23 & 2,71 & 6,14 & 3,61 & 13,20 & 13,20 \\ \text { Hom } & 0,77 & 3,24 & 6,04 & 2,97 & 12,99 & 26,19 \\ \text { Aph } & 2,92 & 0,69 & 5,43 & 2,64 & 11,68 & 37,87 \\ \text { Eu } & 3,04 & 1,00 & 4,96 & 2,37 & 10,66 & 48,53 \\ \text { Mig } & 2,77 & 4,35 & 3,85 & 2,58 & 8,29 & 56,82 \\ \text { Ro } & 0,23 & 1,43 & 2,87 & 1,72 & 6,17 & 62,99 \\ \text { Al } & 3,40 & 2,33 & 2,84 & 1,69 & 6,10 & 69,09 \\ \text { Br } & 0,96 & 1,80 & 2,46 & 1,82 & 5,29 & 74,38 \\ \text { Op } & 1,13 & 0,69 & 2,26 & 1,37 & 4,86 & 79,24\end{array}$




$\begin{array}{lllllll}\mathrm{Mac} & 1,06 & 0,23 & 2,12 & 1,69 & 4,57 & 83,81 \\ \mathrm{Ag} & 0,46 & 0,83 & 1,87 & 2,50 & 4,03 & 87,84 \\ \mathrm{He} & 1,39 & 0,83 & 1,64 & 1,22 & 3,54 & 91,37\end{array}$

Groups 2 \& 9

Average dissimilarity $=39,82$

Group 2 Group 9

$\begin{array}{lrrrrrl}\text { Species } & \text { Av.Abund } & \text { Av.Abund } & \text { Av.Diss } & \text { Diss/SD } & \text { Contrib\% } & \text { Cum.\% } \\ \text { Aph } & 3,59 & 0,69 & 6,40 & 2,79 & 16,07 & 16,07 \\ \text { Eu } & 3,31 & 1,00 & 5,05 & 2,89 & 12,69 & 28,76 \\ \text { Hom } & 1,16 & 3,24 & 4,57 & 2,81 & 11,47 & 40,24 \\ \text { Ch } & 0,77 & 2,71 & 4,28 & 1,97 & 10,75 & 50,99 \\ \text { Op } & 2,52 & 0,69 & 4,07 & 2,57 & 10,22 & 61,21 \\ \mathrm{Al} & 3,75 & 2,33 & 3,20 & 1,63 & 8,03 & 69,24 \\ \mathrm{Mig} & 3,27 & 4,35 & 2,31 & 1,58 & 5,81 & 75,04 \\ \mathrm{Ro} & 0,90 & 1,43 & 1,92 & 1,37 & 4,83 & 79,88 \\ \mathrm{Br} & 1,75 & 1,80 & 1,69 & 1,35 & 4,25 & 84,13 \\ \mathrm{He} & 1,50 & 0,83 & 1,51 & 1,75 & 3,79 & 87,92 \\ \mathrm{Ag} & 0,37 & 0,83 & 1,44 & 1,68 & 3,62 & 91,54\end{array}$

Groups 3 \& 9

Average dissimilarity $=39,17$

$\begin{array}{lrrrrrl}\text { Species } & \text { Group 3 } & \text { Group } 9 & & & & \\ \text { Aph } & \text { Avend } & \text { Av.Abund } & \text { Av.Diss } & \text { Diss/SD } & \text { Contrib\% } & \text { Cum.\% } \\ \text { Eu } & 4,12 & 0,69 & 6,45 & 4,01 & 16,46 & 16,46 \\ \text { Hom } & 3,89 & 1,00 & 5,48 & 7,77 & 13,99 & 30,45 \\ \text { Op } & 0,46 & 3,24 & 5,22 & 3,33 & 13,33 & 43,78 \\ \mathrm{Al} & 3,08 & 0,69 & 4,60 & 3,29 & 11,73 & 55,51 \\ \mathrm{Ag} & 4,17 & 2,33 & 3,44 & 1,88 & 8,77 & 64,29 \\ \mathrm{Br} & 1,42 & 0,83 & 2,27 & 1,08 & 5,79 & 70,08 \\ \mathrm{He} & 2,76 & 1,80 & 1,94 & 1,05 & 4,95 & 75,03 \\ \mathrm{Ch} & 1,76 & 0,83 & 1,81 & 1,38 & 4,61 & 79,64 \\ \mathrm{Do} & 1,94 & 2,71 & 1,50 & 1,25 & 3,82 & 83,46 \\ \mathrm{Ro} & 0,88 & 0,46 & 1,40 & 1,06 & 3,58 & 87,03 \\ & 1,93 & 1,43 & 1,33 & 1,14 & 3,40 & 90,43\end{array}$

Groups 4 \& 9

Average dissimilarity $=31,53$

Group 4 Group 9

$\begin{array}{lrrrrrr}\text { Species } & \text { Av.Abund } & \text { Av.Abund } & \text { Av.Diss } & \text { Diss/SD } & \text { Contrib\% } & \text { Cum.\% } \\ \text { Aph } & 3,17 & 0,69 & 5,21 & 3,09 & 16,51 & 16,51 \\ \text { Hom } & 0,92 & 3,24 & 5,04 & 2,14 & 15,99 & 32,50\end{array}$




$\begin{array}{lllllll}\mathrm{Eu} & 2,33 & 1,00 & 2,83 & 2,96 & 8,97 & 41,47 \\ \mathrm{Op} & 1,92 & 0,69 & 2,64 & 1,78 & 8,38 & 49,85 \\ \mathrm{Al} & 3,16 & 2,33 & 2,61 & 1,37 & 8,28 & 58,14 \\ \mathrm{Br} & 2,39 & 1,80 & 2,21 & 1,41 & 7,02 & 65,16 \\ \mathrm{Ag} & 1,07 & 0,83 & 1,72 & 3,33 & 5,44 & 70,60 \\ \mathrm{Mig} & 3,80 & 4,35 & 1,58 & 1,38 & 5,03 & 75,62 \\ \mathrm{Ro} & 1,36 & 1,43 & 1,57 & 1,22 & 4,97 & 80,59 \\ \mathrm{Ch} & 2,69 & 2,71 & 1,42 & 1,45 & 4,51 & 85,10 \\ \text { Hor } & 0,83 & 0,23 & 1,29 & 1,50 & 4,09 & 89,19 \\ \text { Do } & 1,06 & 0,46 & 1,27 & 1,26 & 4,04 & 93,23\end{array}$

Groups $5 \& 9$

Average dissimilarity $=33,31$

$$
\text { Group } 5 \text { Group } 9
$$

$\begin{array}{lrrrrrl}\text { Species } & \text { Av.Abund } & \text { Av.Abund } & \text { Av.Diss } & \text { Diss/SD } & \text { Contrib\% } & \text { Cum.\% } \\ \text { Hom } & 0,46 & 3,24 & 6,39 & 2,89 & 19,18 & 19,18 \\ \text { Aph } & 2,50 & 0,69 & 4,09 & 2,16 & 12,27 & 31,45 \\ \text { Al } & 2,48 & 2,33 & 2,76 & 1,46 & 8,30 & 39,75 \\ \text { Op } & 1,70 & 0,69 & 2,52 & 1,39 & 7,57 & 47,31 \\ \text { Eu } & 0,69 & 1,00 & 2,38 & 2,04 & 7,15 & 54,46 \\ \text { Ch } & 2,06 & 2,71 & 2,18 & 1,37 & 6,56 & 61,02 \\ \mathrm{Ro} & 2,12 & 1,43 & 1,98 & 1,27 & 5,94 & 66,96 \\ \mathrm{He} & 1,66 & 0,83 & 1,89 & 1,92 & 5,67 & 72,62 \\ \mathrm{Br} & 2,38 & 1,80 & 1,70 & 0,90 & 5,09 & 77,71 \\ \mathrm{Mig} & 3,95 & 4,35 & 1,62 & 1,47 & 4,87 & 82,58 \\ \mathrm{Ag} & 0,96 & 0,83 & 1,56 & 1,81 & 4,67 & 87,25 \\ \mathrm{Do} & 0,46 & 0,46 & 1,42 & 1,35 & 4,27 & 91,52\end{array}$

Groups 6 \& 9

Average dissimilarity $=27,21$

$$
\text { Group } 6 \text { Group } 9
$$

$\begin{array}{lrrrrrr}\text { Species } & \text { Av.Abund } & \text { Av.Abund } & \text { Av.Diss } & \text { Diss/SD } & \text { Contrib\% } & \text { Cum.\% } \\ \text { Hom } & 1,29 & 3,24 & 4,72 & 2,56 & 17,33 & 17,33 \\ \text { Al } & 2,15 & 2,33 & 2,80 & 1,20 & 10,30 & 27,63 \\ \text { Ch } & 1,57 & 2,71 & 2,74 & 1,36 & 10,08 & 37,71 \\ \text { Eu } & 1,03 & 1,00 & 2,23 & 1,38 & 8,20 & 45,91 \\ \text { Br } & 2,52 & 1,80 & 2,19 & 0,97 & 8,06 & 53,96 \\ \text { Ag } & 0,92 & 0,83 & 1,81 & 1,45 & 6,66 & 60,62 \\ \text { Ro } & 1,93 & 1,43 & 1,74 & 1,33 & 6,41 & 67,03 \\ \text { Op } & 1,13 & 0,69 & 1,67 & 1,25 & 6,13 & 73,17 \\ \text { Mig } & 3,97 & 4,35 & 1,58 & 1,78 & 5,82 & 78,99 \\ \text { Aph } & 1,29 & 0,69 & 1,58 & 1,25 & 5,80 & 84,79\end{array}$




$\begin{array}{lllllll}\text { He } & 1,29 & 0,83 & 1,39 & 1,31 & 5,12 & 89,92 \\ \text { Hor } & 0,37 & 0,23 & 1,05 & 0,93 & 3,85 & 93,77\end{array}$

Groups $7 \& 9$

Average dissimilarity $=29,41$

\begin{tabular}{|c|c|c|c|c|c|c|}
\hline & Group 7 & Group 9 & & & & \\
\hline Species & Av.Abund & Av.Abund & Av.Diss & Diss/SD & Contrib\% & Cum.\% \\
\hline Hom & 1,62 & 3,24 & 4,08 & 1,78 & 13,89 & 13,89 \\
\hline $\mathrm{Ch}$ & 1,16 & 2,71 & 3,86 & 2,31 & 13,11 & 27,00 \\
\hline $\mathrm{Al}$ & 1,82 & 2,33 & 3,69 & 1,44 & 12,54 & 39,54 \\
\hline $\mathrm{Br}$ & 2,22 & 1,80 & 2,43 & 1,37 & 8,28 & 47,82 \\
\hline Op & 0,88 & 0,69 & 2,02 & 1,25 & 6,88 & 54,70 \\
\hline $\mathrm{Ag}$ & 1,06 & 0,83 & 1,92 & 1,76 & 6,52 & 61,22 \\
\hline Aph & 0,77 & 0,69 & 1,81 & 1,17 & 6,14 & 67,36 \\
\hline Ro & 1,52 & 1,43 & 1,80 & 1,26 & 6,13 & 73,49 \\
\hline Hor & 0,73 & 0,23 & 1,63 & 1,36 & 5,55 & 79,04 \\
\hline Mig & 4,14 & 4,35 & 1,52 & 1,69 & 5,16 & 84,20 \\
\hline Mac & 0,46 & 0,23 & 1,37 & 0,92 & 4,64 & 88,84 \\
\hline Do & 0,60 & 0,46 & 1,19 & 1,06 & 4,06 & 92,90 \\
\hline
\end{tabular}

\section{Groups 8 \& 9}

Average dissimilarity $=26,55$

$\begin{array}{lrrrrrl} & \text { Group } 8 & \text { Group } 9 & & & & \\ \text { Species } & \text { Av.Abund } & \text { Av.Abund } & \text { Av.Diss } & \text { Diss/SD } & \text { Contrib\% } & \text { Cum.\% } \\ \text { Al } & 2,65 & 2,33 & 2,68 & 1,37 & 10,11 & 10,11 \\ \text { Aph } & 1,32 & 0,69 & 2,56 & 1,31 & 9,63 & 19,74 \\ \text { Hom } & 2,21 & 3,24 & 2,54 & 1,86 & 9,58 & 29,32 \\ \mathrm{Br} & 2,04 & 1,80 & 2,37 & 1,10 & 8,91 & 38,23 \\ \mathrm{Ch} & 2,34 & 2,71 & 2,21 & 1,41 & 8,31 & 46,54 \\ \mathrm{Eu} & 0,23 & 1,00 & 1,95 & 1,23 & 7,34 & 53,88 \\ \mathrm{Ro} & 2,11 & 1,43 & 1,92 & 1,23 & 7,22 & 61,10 \\ \mathrm{Ag} & 1,43 & 0,83 & 1,58 & 1,21 & 5,94 & 67,04 \\ \mathrm{Mig} & 4,30 & 4,35 & 1,56 & 1,62 & 5,87 & 72,91 \\ \mathrm{He} & 0,90 & 0,83 & 1,54 & 1,77 & 5,82 & 78,73 \\ \text { Hor } & 0,69 & 0,23 & 1,44 & 1,11 & 5,41 & 84,14 \\ \text { Op } & 0,60 & 0,69 & 1,41 & 1,18 & 5,29 & 89,43 \\ \text { Do } & 0,00 & 0,46 & 1,06 & 1,32 & 3,99 & 93,42\end{array}$

Groups $1 \& 10$

Average dissimilarity $=45,36$

Group 1 Group 10

$\begin{array}{llllll}\text { Species Av.Abund Av.Abund } & \text { Av.Diss } & \text { Diss/SD } & \text { Contrib\% } & \text { Cum.\% }\end{array}$ 


$\begin{array}{lllllrl}\text { Hom } & 0,77 & 3,88 & 7,03 & 3,04 & 15,49 & 15,49 \\ \mathrm{Eu} & 3,04 & 1,06 & 4,53 & 2,39 & 9,98 & 25,47 \\ \mathrm{Ag} & 0,46 & 2,27 & 4,25 & 1,99 & 9,37 & 34,84 \\ \mathrm{Aph} & 2,92 & 1,23 & 3,94 & 1,60 & 8,69 & 43,53 \\ \mathrm{Ro} & 0,23 & 1,85 & 3,67 & 2,04 & 8,08 & 51,61 \\ \mathrm{He} & 1,39 & 0,00 & 3,25 & 2,25 & 7,17 & 58,78 \\ \mathrm{Ch} & 0,23 & 1,40 & 2,67 & 1,46 & 5,88 & 64,66 \\ \mathrm{Mig} & 2,77 & 3,93 & 2,62 & 3,14 & 5,79 & 70,45 \\ \mathrm{Br} & 0,96 & 2,08 & 2,46 & 1,44 & 5,43 & 75,88 \\ \mathrm{Al} & 3,40 & 2,40 & 2,22 & 1,58 & 4,89 & 80,77 \\ \mathrm{Do} & 0,00 & 0,83 & 1,91 & 4,98 & 4,21 & 84,98 \\ \text { Mac } & 1,06 & 0,23 & 1,90 & 1,81 & 4,20 & 89,18 \\ \text { Met } & 0,37 & 0,65 & 1,72 & 0,94 & 3,79 & 92,97\end{array}$

Groups $2 \& 10$

Average dissimilarity $=38,31$

$\begin{array}{lrrrrrl} & \text { Group 2 } & \text { Group 10 } & & & & \\ \text { Species } & \text { Av.Abund } & \text { Av.Abund } & \text { Av.Diss } & \text { Diss/SD } & \text { Contrib\% } & \text { Cum.\% } \\ \text { Hom } & 1,16 & 3,88 & 5,54 & 2,75 & 14,45 & 14,45 \\ \text { Aph } & 3,59 & 1,23 & 4,90 & 1,85 & 12,80 & 27,25 \\ \text { Eu } & 3,31 & 1,06 & 4,65 & 2,93 & 12,14 & 39,39 \\ \text { Ag } & 0,37 & 2,27 & 3,96 & 2,38 & 10,33 & 49,72 \\ \mathrm{He} & 1,50 & 0,00 & 3,12 & 4,27 & 8,13 & 57,85 \\ \mathrm{Al} & 3,75 & 2,40 & 2,76 & 1,76 & 7,20 & 65,05 \\ \mathrm{Op} & 2,52 & 1,36 & 2,41 & 3,32 & 6,28 & 71,33 \\ \mathrm{Ro} & 0,90 & 1,85 & 2,20 & 1,14 & 5,75 & 77,08 \\ \mathrm{Ch} & 0,77 & 1,40 & 1,95 & 1,33 & 5,09 & 82,17 \\ \mathrm{Met} & 0,46 & 0,65 & 1,61 & 0,93 & 4,21 & 86,38 \\ \mathrm{Br} & 1,75 & 2,08 & 1,57 & 1,36 & 4,10 & 90,48\end{array}$

Groups 3 \& 10

Average dissimilarity $=38,75$

Group 3 Group 10

$\begin{array}{lrrrrrl}\text { Species } & \text { Av.Abund } & \text { Av.Abund } & \text { Av.Diss } & \text { Diss/SD } & \text { Contrib\% } & \text { Cum.\% } \\ \text { Hom } & 0,46 & 3,88 & 6,04 & 3,30 & 15,59 & 15,59 \\ \text { Aph } & 4,12 & 1,23 & 5,14 & 2,42 & 13,26 & 28,86 \\ \text { Eu } & 3,89 & 1,06 & 5,10 & 8,45 & 13,16 & 42,02 \\ \mathrm{He} & 1,76 & 0,00 & 3,20 & 2,67 & 8,25 & 50,27 \\ \mathrm{Al} & 4,17 & 2,40 & 3,13 & 2,32 & 8,08 & 58,35 \\ \mathrm{Op} & 3,08 & 1,36 & 3,11 & 4,61 & 8,04 & 66,38 \\ \mathrm{Ag} & 1,42 & 2,27 & 3,10 & 2,45 & 8,01 & 74,39 \\ \mathrm{Ch} & 1,94 & 1,40 & 1,54 & 2,43 & 3,97 & 78,36\end{array}$




$\begin{array}{lllllll}\text { Br } & 2,76 & 2,08 & 1,49 & 1,03 & 3,84 & 82,21 \\ \text { Ro } & 1,93 & 1,85 & 1,33 & 1,73 & 3,44 & 85,65 \\ \text { Do } & 0,88 & 0,83 & 1,27 & 1,43 & 3,29 & 88,94 \\ \text { Met } & 0,23 & 0,65 & 1,26 & 0,88 & 3,25 & 92,19\end{array}$

Groups 4 \& 10

Average dissimilarity $=31,99$

$\begin{array}{lrrrrrl} & \text { Group 4 } & \text { Group 10 } & & & & \\ \text { Species } & \text { Av.Abund } & \text { Av.Abund } & \text { Av.Diss } & \text { Diss/SD } & \text { Contrib\% } & \text { Cum.\% } \\ \text { Hom } & 0,92 & 3,88 & 5,95 & 2,31 & 18,61 & 18,61 \\ \text { Aph } & 3,17 & 1,23 & 3,82 & 1,69 & 11,95 & 30,56 \\ \text { Ch } & 2,69 & 1,40 & 2,65 & 1,53 & 8,29 & 38,86 \\ \text { Eu } & 2,33 & 1,06 & 2,57 & 3,82 & 8,03 & 46,89 \\ \mathrm{Ag} & 1,07 & 2,27 & 2,53 & 1,15 & 7,90 & 54,80 \\ \mathrm{Al} & 3,16 & 2,40 & 2,13 & 1,25 & 6,66 & 61,45 \\ \mathrm{He} & 0,92 & 0,00 & 1,92 & 2,11 & 6,01 & 67,46 \\ \mathrm{Ro} & 1,36 & 1,85 & 1,83 & 1,28 & 5,71 & 73,17 \\ \mathrm{Br} & 2,39 & 2,08 & 1,80 & 1,29 & 5,62 & 78,79 \\ \mathrm{Met} & 0,46 & 0,65 & 1,59 & 1,39 & 4,98 & 83,77 \\ \text { Hor } & 0,83 & 0,23 & 1,20 & 1,50 & 3,77 & 87,54 \\ \text { Op } & 1,92 & 1,36 & 1,11 & 1,61 & 3,46 & 91,00\end{array}$

Groups $5 \& 10$

Average dissimilarity $=34,84$

$\begin{array}{lrrrrrl}\text { Species } & \text { Group 5 } & \text { Group 10 } & & & & \\ \text { Hom } & \text { Av.Abund } & \text { Av.Abund } & \text { Av.Diss } & \text { Diss/SD } & \text { Contrib\% } & \text { Cum.\% } \\ \text { He } & 0,46 & 3,88 & 7,28 & 2,98 & 20,88 & 20,88 \\ \text { Aph } & 1,66 & 0,00 & 3,54 & 4,71 & 10,16 & 31,05 \\ \text { Ag } & 2,50 & 1,23 & 2,93 & 1,41 & 8,41 & 39,45 \\ \text { Al } & 0,96 & 2,27 & 2,84 & 1,59 & 8,15 & 47,60 \\ \text { Eu } & 2,48 & 2,40 & 2,42 & 1,62 & 6,95 & 54,55 \\ \text { Ch } & 0,69 & 1,06 & 2,26 & 3,35 & 6,49 & 61,04 \\ \text { Ro } & 2,06 & 1,40 & 2,13 & 1,32 & 6,11 & 67,15 \\ \text { Do } & 2,12 & 1,85 & 1,65 & 1,48 & 4,73 & 71,88 \\ \text { Met } & 0,46 & 0,83 & 1,58 & 3,35 & 4,53 & 76,41 \\ \text { Br } & 0,23 & 0,65 & 1,50 & 0,91 & 4,31 & 80,72 \\ \text { Mac } & 2,38 & 2,08 & 1,47 & 1,18 & 4,21 & 84,93 \\ \text { Op } & 0,69 & 0,23 & 1,28 & 1,19 & 3,69 & 88,62 \\ & 1,70 & 1,36 & 1,13 & 1,10 & 3,23 & 91,85\end{array}$


Groups 6 \& 10

Average dissimilarity $=31,22$

Group 6 Group 10

$\begin{array}{lrrrrrl}\text { Species } & \text { Av.Abund } & \text { Av.Abund } & \text { Av.Diss } & \text { Diss/SD } & \text { Contrib\% } & \text { Cum.\% } \\ \text { Hom } & 1,29 & 3,88 & 5,78 & 2,60 & 18,51 & 18,51 \\ \mathrm{Ag} & 0,92 & 2,27 & 3,39 & 1,54 & 10,86 & 29,37 \\ \mathrm{He} & 1,29 & 0,00 & 3,00 & 2,50 & 9,61 & 38,98 \\ \mathrm{Al} & 2,15 & 2,40 & 2,67 & 1,66 & 8,54 & 47,52 \\ \mathrm{Eu} & 1,03 & 1,06 & 2,11 & 1,80 & 6,76 & 54,28 \\ \mathrm{Ch} & 1,57 & 1,40 & 1,88 & 1,53 & 6,02 & 60,31 \\ \mathrm{Br} & 2,52 & 2,08 & 1,82 & 1,14 & 5,83 & 66,14 \\ \mathrm{Aph} & 1,29 & 1,23 & 1,76 & 1,47 & 5,64 & 71,78 \\ \mathrm{Ro} & 1,93 & 1,85 & 1,60 & 1,91 & 5,12 & 76,90 \\ \text { Met } & 0,00 & 0,65 & 1,40 & 0,67 & 4,47 & 81,37 \\ \text { Do } & 0,23 & 0,83 & 1,32 & 1,54 & 4,24 & 85,61 \\ \text { Mir } & 0,00 & 0,46 & 1,01 & 1,33 & 3,24 & 88,84 \\ \text { Hor } & 0,37 & 0,23 & 0,98 & 0,94 & 3,15 & 92,00\end{array}$

Groups $7 \& 10$

Average dissimilarity $=30,87$

$\begin{array}{lrrrrrl} & \text { Group 7 } & \text { Group 10 } & & & & \\ \text { Species } & \text { Av.Abund } & \text { Av.Abund } & \text { Av.Diss } & \text { Diss/SD } & \text { Contrib\% } & \text { Cum.\% } \\ \text { Hom } & 1,62 & 3,88 & 5,12 & 1,86 & 16,60 & 16,60 \\ \mathrm{Al} & 1,82 & 2,40 & 3,48 & 1,86 & 11,28 & 27,88 \\ \mathrm{Ag} & 1,06 & 2,27 & 3,15 & 1,46 & 10,20 & 38,08 \\ \mathrm{Aph} & 0,77 & 1,23 & 2,45 & 1,31 & 7,93 & 46,01 \\ \text { Op } & 0,88 & 1,36 & 2,13 & 1,84 & 6,90 & 52,91 \\ \mathrm{Ro} & 1,52 & 1,85 & 2,03 & 1,42 & 6,58 & 59,49 \\ \mathrm{Br} & 2,22 & 2,08 & 2,03 & 1,50 & 6,57 & 66,06 \\ \mathrm{Ch} & 1,16 & 1,40 & 1,56 & 1,47 & 5,06 & 71,12 \\ \text { Hor } & 0,73 & 0,23 & 1,52 & 1,37 & 4,92 & 76,04 \\ \text { Met } & 0,00 & 0,65 & 1,44 & 0,66 & 4,68 & 80,71 \\ \text { Mac } & 0,46 & 0,23 & 1,30 & 0,98 & 4,20 & 84,92 \\ \text { He } & 0,46 & 0,00 & 1,05 & 1,32 & 3,39 & 88,31 \\ \text { Mir } & 0,00 & 0,46 & 1,05 & 1,32 & 3,39 & 91,70\end{array}$

Groups $8 \& 10$

Average dissimilarity $=31,33$

Group 8 Group 10

$\begin{array}{lrrrrrl}\text { Species } & \text { Av.Abund } & \text { Av.Abund } & \text { Av.Diss } & \text { Diss/SD } & \text { Contrib\% } & \text { Cum.\% } \\ \text { Hom } & 2,21 & 3,88 & 3,62 & 1,84 & 11,55 & 11,55 \\ \text { Ch } & 2,34 & 1,40 & 2,78 & 1,37 & 8,88 & 20,43\end{array}$




$\begin{array}{lllllll}\text { Aph } & 1,32 & 1,23 & 2,49 & 1,19 & 7,94 & 28,37 \\ \mathrm{Al} & 2,65 & 2,40 & 2,35 & 1,58 & 7,49 & 35,86 \\ \mathrm{Ag} & 1,43 & 2,27 & 2,22 & 1,33 & 7,08 & 42,94 \\ \mathrm{Br} & 2,04 & 2,08 & 2,22 & 1,31 & 7,08 & 50,03 \\ \mathrm{He} & 0,90 & 0,00 & 1,91 & 1,24 & 6,09 & 56,11 \\ \mathrm{Eu} & 0,23 & 1,06 & 1,91 & 1,70 & 6,08 & 62,20 \\ \mathrm{Do} & 0,00 & 0,83 & 1,83 & 4,59 & 5,84 & 68,03 \\ \text { Op } & 0,60 & 1,36 & 1,77 & 1,34 & 5,65 & 73,68 \\ \mathrm{Ro} & 2,11 & 1,85 & 1,70 & 2,17 & 5,43 & 79,11 \\ \text { Met } & 0,00 & 0,65 & 1,36 & 0,66 & 4,33 & 83,44 \\ \text { Hor } & 0,69 & 0,23 & 1,34 & 1,12 & 4,29 & 87,72 \\ \text { Mig } & 4,30 & 3,93 & 1,20 & 1,19 & 3,83 & 91,56\end{array}$

Groups $9 \& 10$

Average dissimilarity $=27,51$

$$
\text { Group } 9 \text { Group } 10
$$

$\begin{array}{lrrrrrl}\text { Species } & \text { Av.Abund } & \text { Av.Abund } & \text { Av.Diss } & \text { Diss/SD } & \text { Contrib\% } & \text { Cum.\% } \\ \mathrm{Ag} & 0,83 & 2,27 & 3,21 & 2,62 & 11,68 & 11,68 \\ \mathrm{Ch} & 2,71 & 1,40 & 3,18 & 1,70 & 11,54 & 23,22 \\ \mathrm{Hom} & 3,24 & 3,88 & 2,51 & 1,59 & 9,13 & 32,36 \\ \mathrm{Aph} & 0,69 & 1,23 & 2,21 & 1,35 & 8,02 & 40,38 \\ \mathrm{Br} & 1,80 & 2,08 & 1,98 & 1,16 & 7,19 & 47,57 \\ \mathrm{Ro} & 1,43 & 1,85 & 1,94 & 1,35 & 7,06 & 54,63 \\ \mathrm{He} & 0,83 & 0,00 & 1,85 & 4,58 & 6,74 & 61,36 \\ \mathrm{Al} & 2,33 & 2,40 & 1,76 & 1,17 & 6,40 & 67,77 \\ \mathrm{Op} & 0,69 & 1,36 & 1,69 & 1,29 & 6,15 & 73,91 \\ \mathrm{Mig} & 4,35 & 3,93 & 1,60 & 1,33 & 5,82 & 79,74 \\ \mathrm{Met} & 0,00 & 0,65 & 1,37 & 0,67 & 4,98 & 84,71 \\ \text { Mir } & 0,00 & 0,46 & 0,99 & 1,33 & 3,60 & 88,32 \\ \text { Eu } & 1,00 & 1,06 & 0,98 & 1,39 & 3,56 & 91,87\end{array}$

\section{Copyrights}

Copyright for this article is retained by the author(s), with first publication rights granted to the journal.

This is an open-access article distributed under the terms and conditions of the Creative Commons Attribution license (http://creativecommons.org/licenses/by/3.0/). 